Fissile Materials Disposition Program

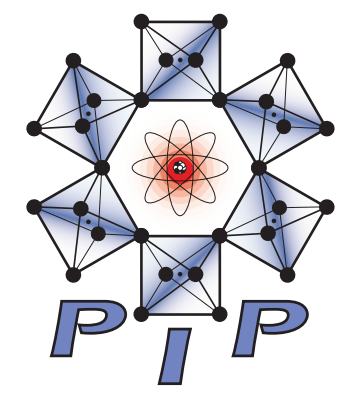

\title{
EIS Data Call Report: Plutonium Immobilization Plant Using Glass in New Facilities at the Savannah River Site
}

June 1998

Plutonium Immobilization Project

Law rence Livermore National Laboratory Livermore, California 94550 
UCRL-ID-128271

\section{DISCLAIMER}

This document was prepared as an account of work sponsored by an agency of the United States Government. Neither the United States Government nor the University of California nor any of their employees, makes any warranty, express or implied, or assumes any legal liability or responsibility for the accuracy, completeness, or usefulness of any information, apparatus, product, or process disclosed, or represents that its use would not infringe privately owned rights. Reference herein to any specific commercial product, process, or service by trade name, trademark, manufacturer, or otherwise, does not necessarily constitute or imply its endorsement, recommendation, or favoring by the United States Government or the University of California. The views and opinions of authors expressed herein do not necessarily state or reflect those of the United States Government or the University of California, and shall not be used for advertising or product endorsement purposes.

This report has been reproduced

directly from the best available copy.

Available to DOE and DOE contractors from the

Office of Scientific and Technical Information

P.O. Box 62, Oak Ridge, TN 37831

Prices available from (423) 576-8401

Available to the public from the

National Technical Information Service

U.S. Department of Commerce

5285 Port Royal Rd.,

Springfield, VA 22161

Work performed under the auspices of the U.S. Department of Energy by Lawrence Livermore National Laboratory under Contract W-7405-ENG-48. 



\title{
Fissile Materials Disposition Program
}

\author{
EIS Data Call Input Report: \\ Plutonium Immobilization Plant \\ Using Glass in New Facilities \\ at the Savannah River Site
}

June 1998 
UCRL-ID-128271 


\section{Acknowledgments}

Organizations that provided major contributions to the development of this report include:

- Lawrence Livermore National Laboratory (LLNL)

- Westinghouse Savannah River Corporation (WSRC)

- Bechtel

- Babcock \& Wilcox Hanford Corporation (BWHC)

- Lockheed Martin Hanford Corporation (LMHC)

This document was co-authored or reviewed by:

\begin{tabular}{llll}
\hline Name & Affiliation & Name & Affiliation \\
\hline Guy Armantrout & LLNL & Tom Severnyse & WSRC \\
Ted Breitmayer & Bechtel & Wendel Snyder & Bechtel \\
Mark Bronson & LLNL & Danilo Tiojanco & Bechtel \\
William Brummond & LLNL & R. E. Vail & WSRC \\
Tom Crawford & LMHC & Richard Van Konynenberg & LLNL \\
Al DiSabatino* & LLNL & David Warren & Bechtel \\
Bart Ebbinghaus & LLNL & Joong Yang & M. H. Chew \\
Tom Gould & WSRC & & \& Associates \\
Leonard W. Gray & LLNL & & \\
Harold Howell & Bechtel & & \\
Robert Jones & WSRC & & \\
Bob Kaiser & Bechtel & & \\
Tehmau Kan & LLNL & & \\
J. D. Lee & LLNL & & \\
Dan Loftus & Bechtel & & \\
Brian Marais & Bechtel & & \\
Paul Maddux & WSRC & & \\
Chan Pang & Bechtel & & \\
Max Pong & Bechtel & & \\
Don Sandberg & BWHC & & \\
Eric Schogren & WSRC & &
\end{tabular}

* Author to whom all questions should be directed. 
UCRL-ID-128271 


\section{Contents}

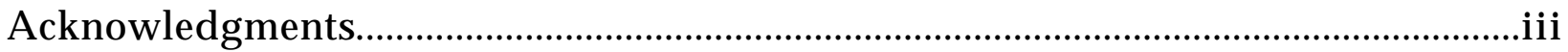

1.0 Plutonium Immobilization Plant Using Glass in New Facilities at the Savannah River Site: Mission, Assumptions, and Design Basis...........................1-1

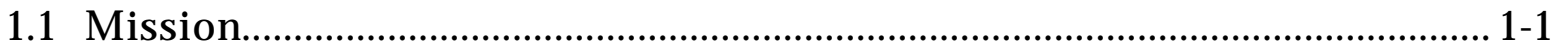

1.1.1 Immobilization............................................................................... 1-2

1.1.2 Glass Immobilization Form................................................................ 1-3

1.2 Assumptions and Design Basis.................................................................. 1-4

1.2.1 Program Assumptions ..................................................................... 1-4

1.2.2 PIP Assumptions and Design Basis....................................................... 1-5

1.2.3 Facility Capacity/Capability ……………….......................................... 1-6

1.2.4 Facility Operating Basis...................................................................... 1-7

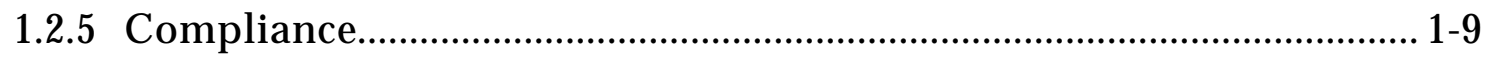

2.0 Plutonium Immobilization Plant Facility Description............................................ 2-1

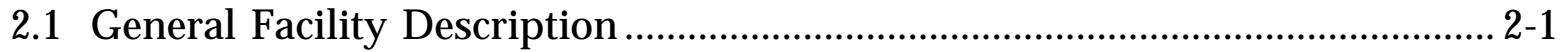

2.1.1 Functional Description .......................................................................... $2-1$

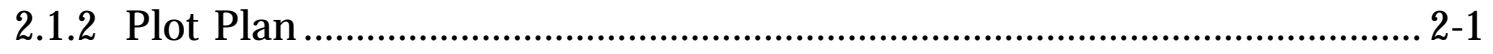

2.1.3 Building Descriptions....................................................................... 2-5

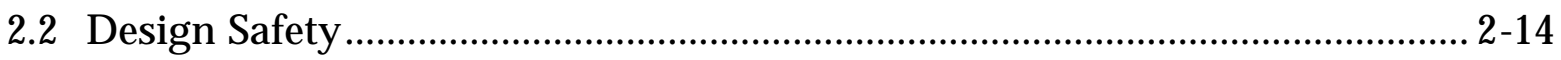

2.2.1 Confinement Systems and Barriers …….......................................... 2-15

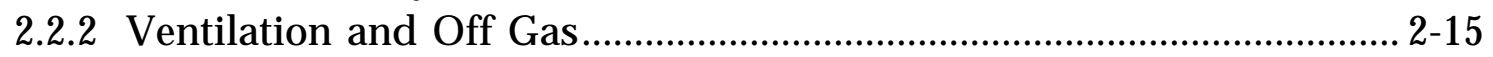

2.2.3 Natural Phenomena.......................................................................... 2-15

2.2.4 Systems Related to Safety ……....................................................... 2-16

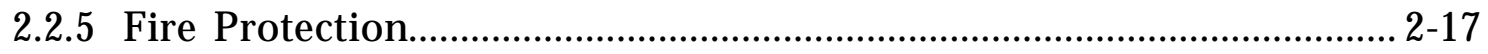

2.2.6 Safety Class Instrumentation and Control .......................................... 2-17

2.2.7 Nuclear Criticality ……..................................................................... 2-18

2.2.8 Ventilation and Confinement ........................................................... 2-19

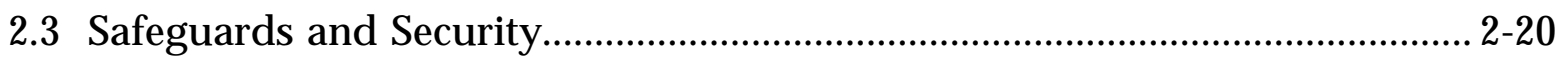

2.3.1 Requirements for the Physical Protection of Category I Special Nuclear Material and Other Vital Equipment.......................... 2-21

3.0 Site Map and Land Use Requirements ............................................................... 3-1

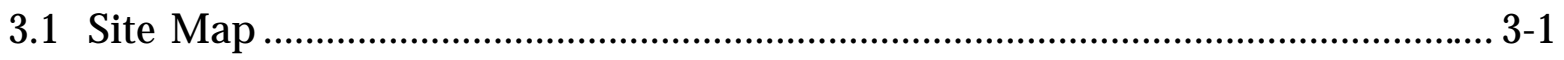

3.2 Land Area Requirements During Operation.................................................... 3-1

3.3 Land Area Requirements During Construction ................................................ 3-1

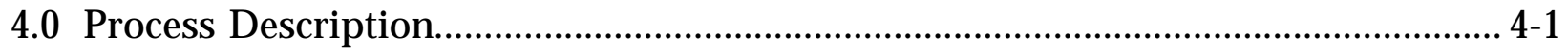

4.1 Plutonium Feed Conversion ........................................................................ 4-1 
4.1.1 Material Receiving............................................................................ 4-3

4.1.2 Feed Material Storage Vault ................................................................... 4-4

4.1.3 Unpacking and Sorting......................................................................... 4-5

4.1.4 Fuel Decladding................................................................................ 4-6

4.1.5 Metal to Oxide Conversion ................................................................ 4-7

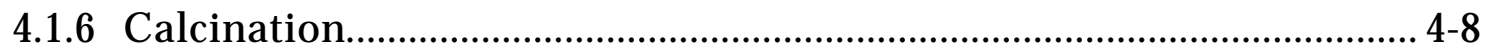

4.1.7 Halide Removal ............................................................................. 4-9

4.1.8 Sample Preparation and Product Assay …......................................... 4-10

4.1.9 In-Process Storage Vault....................................................................... 4-11

4.2 First-Stage Immobilization - Immobilization in Glass................................ 4-12

4.2.1 Melter Feed Preparation ..................................................................... 4-12

4.2.2 Melter Operation/Plutonium Glass Production.................................... 4-14

4.3 Second-Stage Immobilization with High Level Waste Glass ........................ 4-15

4.3.1 Canister Loading.................................................................................. 4-15

4.3.2 Canister Filling ………………........................................................ 4-18

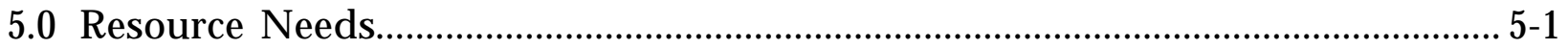

5.1 Materials/Resources Consumed During Construction.................................... 5-1

5.2 Materials/Resources Consumed During Operation ......................................... 5-2

5.2.1 Utilities Consumed.............................................................................. 5-2

5.2.2 Water Balance .................................................................................... 5-3

5.2.3 Chemicals Consumed ………………............................................... 5-5

5.2.4 Radiological Materials Required.............................................................. 5-5

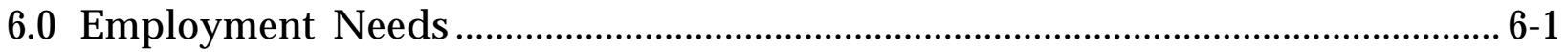

6.1 Employment Needs During Construction ...................................................... 6-1

6.2 Employment Needs During Operation........................................................... 6-1

6.3 Badged Employees at Risk of Radiological Exposure ........................................ 6-2

7.0 Wastes and Emissions from the Facility ……......................................................

7.1 Wastes and Emissions During Construction..................................................... 7-1

7.1.1 Solid and Liquid Wastes......................................................................

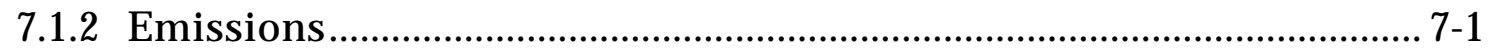

7.2 Wastes and Emissions During Operation .....................................................

7.2.1 Solid and Liquid Wastes.......................................................................

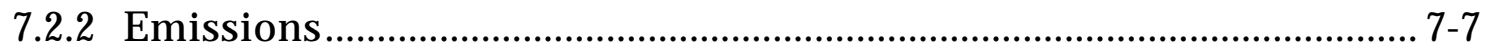

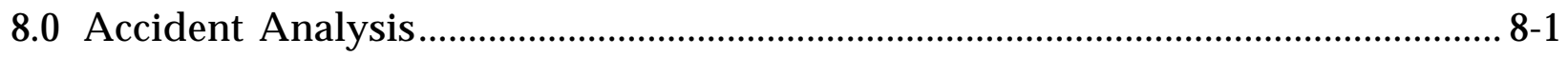

8.1 Accident Analysis and Risk Assessment...................................................... 8-1

8.2 Accident Description................................................................................... 8-1

8.2.1 Natural Phenomena......................................................................... 8-1

8.2.2 Externally Induced Failures ................................................................ 8-2 
8.2.3 High Energetic Events....................................................................... 8-2

8.2.4 Medium Energetic Events................................................................ 8-2

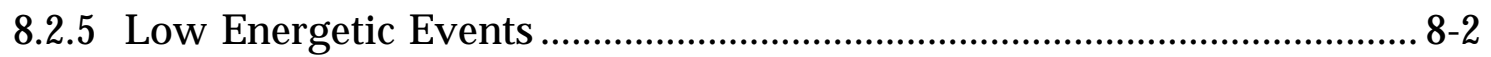

8.3 Accident Sequences ........................................................................................ 8-3

8.4 Plutonium Conversion Accident Sequences................................................. 8-3

8.4.1 Criticality in Halide Wash Accident ........................................................ 8-3

8.4.2 Criticality in HYDOX Furnace ............................................................... 8-4

8.4.3 Criticality in Sorting/Unpackaging Glovebox ...................................... 8-6

8.4.4 Explosion in HYDOX Furnace......................................................... 8-9

8.4.5 Furnace-Initiated Glovebox Fire....................................................... 8-10

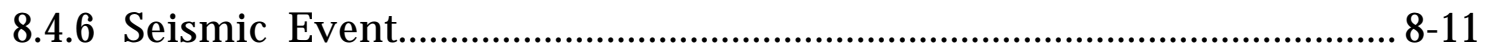

8.4.7 Vault Criticality ............................................................................... 8-12

8.4.8 Hydrogen Explosion in Plutonium Conversion Room...................... 8-12

8.5 First-Stage Immobilization Glass Accident Sequences .................................. 8-14

8.5.1 Criticality in Rotary Splitter Tumbler.................................................. 8-14

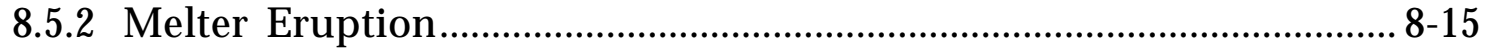

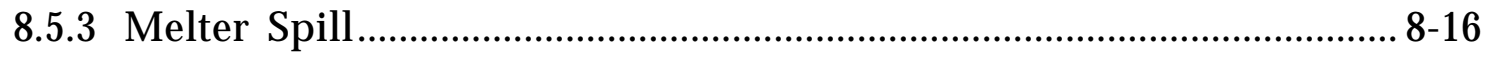

8.5.4 Seismic Event....................................................................................... 8-17

8.6 Second-Stage Immobilization - Canister Loading, Transport, and HLW Glass Pour Accident Sequences ……............................................. 8-19

8.6.1 Can Handling Accident....................................................................... 8-19

8.6.2 Transportation Accident................................................................ 8-19

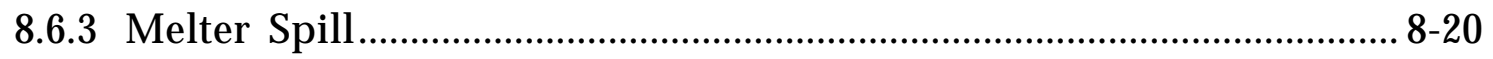

8.6.4 Canister Handling Accident................................................................ 8-20

8.7 Beyond Design Basis Seismic Event ............................................................. 8-20

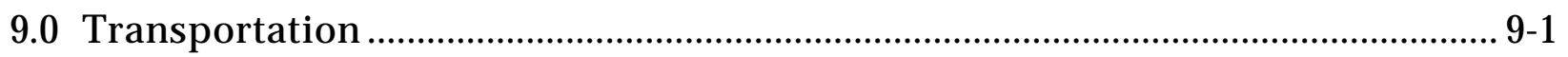

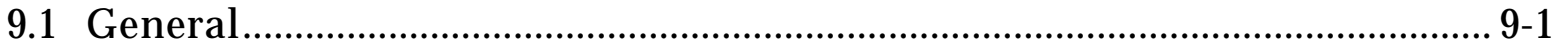

9.1.1 Shipping Responsibilities................................................................... 9-1

9.1.2 Packaging Responsibilities .................................................................... 9-2

9.2 Construction-Related Transportation Requirements...................................... 9-2

9.3 Operations-Related Transportation Requirements......................................... 9-3

9.3.1 Intersite Transportation........................................................................ 9-3

9.3.2 Intrasite Transportation.................................................................... 9-5

10.0 Deactivation and Decontamination …................................................................

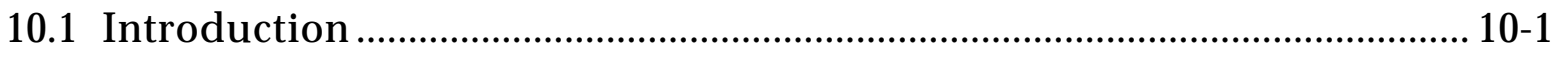

10.2 Deactivation and Decontamination Approach .......................................... 10-1

10.3 Decontamination Process Plan.................................................................. 10-1

10.4 Deactivation and Decontamination Operations ......................................... 10-1

10.5 Deactivation and Decontamination Generated Wastes and Emissions..................................................................................... 10-2 
UCRL-ID-128271

11.0 List of Abbreviations and Acronyms.......................................................... 11-1 Appendix A - Hybrid Case..................................................................................... A-1 


\section{List of Figures}

Figure 1-1. Immobilization of Surplus Fissile Materials ........................................... 1-1

Figure 1-2. Nominal Can-in-Canister Design .......................................................... 1-2

Figure 2-1. Plutonium Immobilization Facilities Flow Diagram ........................... 2-2

Figure 2-2. $\quad$ F-Area Plot Plan for Plutonium Immobilization Plant ........................ 2-3

Figure 2-3. Plutonium Processing Building Layout - Main Process Level............ 2-6

Figure 2-4. Canister Assembly Area in Basement..................................................... 2-8

Figure 2-5. Above-Grade Structures for Main Process Building ........................... 2-10

Figure 2-6. Actinide Packaging and Storage Facility .............................................. 2-11

Figure 2-7. Plutonium Can-in-Canister Receipt Area at DWPF and Transfer Route to DWPF Melt Cell................................................. 2-12

Figure 3-1. Savannah River Site Site Map............................................................... 3-2

Figure 3-2. $\quad$ F-Area Plot Plan ........................................................................ 3-3

Figure 3-3. E-Area and Surrounding Areas Site Plan............................................... 3-4

Figure 3-4. C-Area and N-Area Site Plan ........................................................... 3-5

Figure 4-1. Plutonium Conversion Block Flow Diagram ....................................... 4-2

Figure 4-2. First-Stage Immobilization Block Flow Diagram ................................. 4-13

Figure 4-3. Second-Stage Immobilization Canister Loading Block Flow Diagram

Figure 4-4. Second-Stage Immobilization Canister Filling Block Flow Diagram

Figure 5-1. Annual Water Balance for Plutonium Immobilization in Glass Using New Facilities at SRS.

\section{List of Tables}

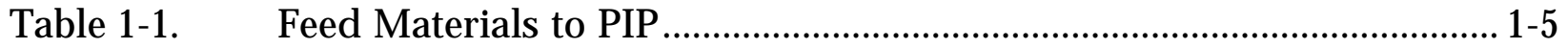

Table 1-2. Facility Schedule .......................................................................... 1-8

Table 1-3. Crosswalk: Partial Listing of Canceled DOE Orders to New DOE Orders.................................................................................. 1-10

Table 2-1. Plutonium Conversion and Immobilization Facility Data.................. 2-5

Table 3-1. Construction Area Requirements....................................................... 3-6

Table 5-1. Resource Needs for Construction .......................................................... 5-1

Table 5-2. Resource Needs During Operation......................................................... 5-2 
Table 6-1. Employment During Construction............................................................ 6-1

Table 6-2. Annual Employment Requirements During Operation ...................... 6-2

Table 6-3. Radiation Doses to On-Site Workers During Construction................. 6-3

Table 6-4. Radiation Doses to On-Site Workers During Operations..................... 6-3

Table 7-1. $\quad$ Estimated Waste Generated During Construction.................................. 7-2

Table 7-2. Air Emissions During Construction....................................................... 7-3

Table 7-3. Radioactive Releases from Construction ............................................... 7-3

Table 7-4. $\quad$ Estimated Waste Generation During Operation...................................... 7-4

Table 7-5(a). Powerhouse Air Emissions During Operation ........................................ 7-5

Table 7-5(b). Diesel Air Emissions During Operation............................................... 7-5

Table 7-5(c). Process Air Emissions During Operation............................................... 7-5

Table 7-6. Radioactive Releases During Operation................................................. 7-6

Table 8-1. Frequency Evaluation Ranges............................................................ 8-3

Table 8-2. Fission Yield from $1 \times 10^{19}$ Fissions in an Oxide Powder...................... 8-5

Table 8-3. Halide Wash Criticality Non-Volatile Source Term .............................. 8-6

Table 8-4. Fission Yield from $1 \times 10^{19}$ Fissions in a Metal...................................... 8-7

Table 8-5. HYDOX Furnace and Sort and Inspect Glovebox

Criticality Metal Melt Source Term ……………….................................. 8-9

Table 8-6. Explosion in the HYDOX Furnace Source Term.................................. 8-10

Table 8-7. Calcining Furnace Initiated Glovebox Fire Source Term .................... 8-11

Table 8-8. Plutonium Conversion Contribution to the Seismic

Event Source Term............................................................................... 8-12

Table 8-9. Vault Criticality Non-Volatile Source Term......................................... 8-13

Table 8-10. Explosion in the Plutonium Conversion Segment Source Term ... 8-14

Table 8-11. Rotary Splitter Tumbler Criticality Non-Volatile Source Term ....... 8-15

Table 8-12. Melter Eruption Source Term............................................................. 8-16

Table 8-13. Melter Spill Source Term................................................................ 8-17

Table 8-14(a). Glass Immobilization Process Component Seismic

Event Source Terms ........................................................................... 8-18

Table 8-14(b). Glass Immobilization Process Component Seismic

Event Source Terms, Melter Spill

Table 8-15. Plutonium Conversion Contribution to the BEU

Event Source Term.

Table 8-16(a). Glass Immobilization Process Component BEU

Seismic Event Source Terms.

Table 8-16(b). Glass Immobilization Process Component BEU

Event Source Terms, Melter Spill 
Table 9-1. Annual Transportation Requirements During Construction............ 9-3

Table 9-2. Process Material Shipments During Operation ...................................... 9-4

Table 9-3. Intrasite Transport of "Canned" Plutonium to the Facility ................. 9-6 
UCRL-ID-128271 


\subsection{Plutonium Immobilization Plant Using Glass in New Facilities at the Savannah River Site: Mission, Assumptions, and Design Basis}

\subsection{Mission}

The Plutonium Immobilization Plant (PIP) accepts plutonium (Pu) from pit conversion and from non-pit sources and, through a glass immobilization process, converts the plutonium into an immobilized form that can be disposed of in a high level waste (HLW) repository. This immobilization process is shown conceptually in Figure 1-1. The objective is to make an immobilized form, suitable for geologic disposal, in which the plutonium is as inherently unattractive and inaccessible as the plutonium in spent fuel from commercial reactors.

The glass immobilization alternative presented in this report consists of first converting the surplus material to an oxide, followed by incorporating the oxide in a lanthanide borosilicate (LaBS) glass. The plutonium-glass is produced in a melter and poured into metal cans. These cans are then placed in an outer can that is

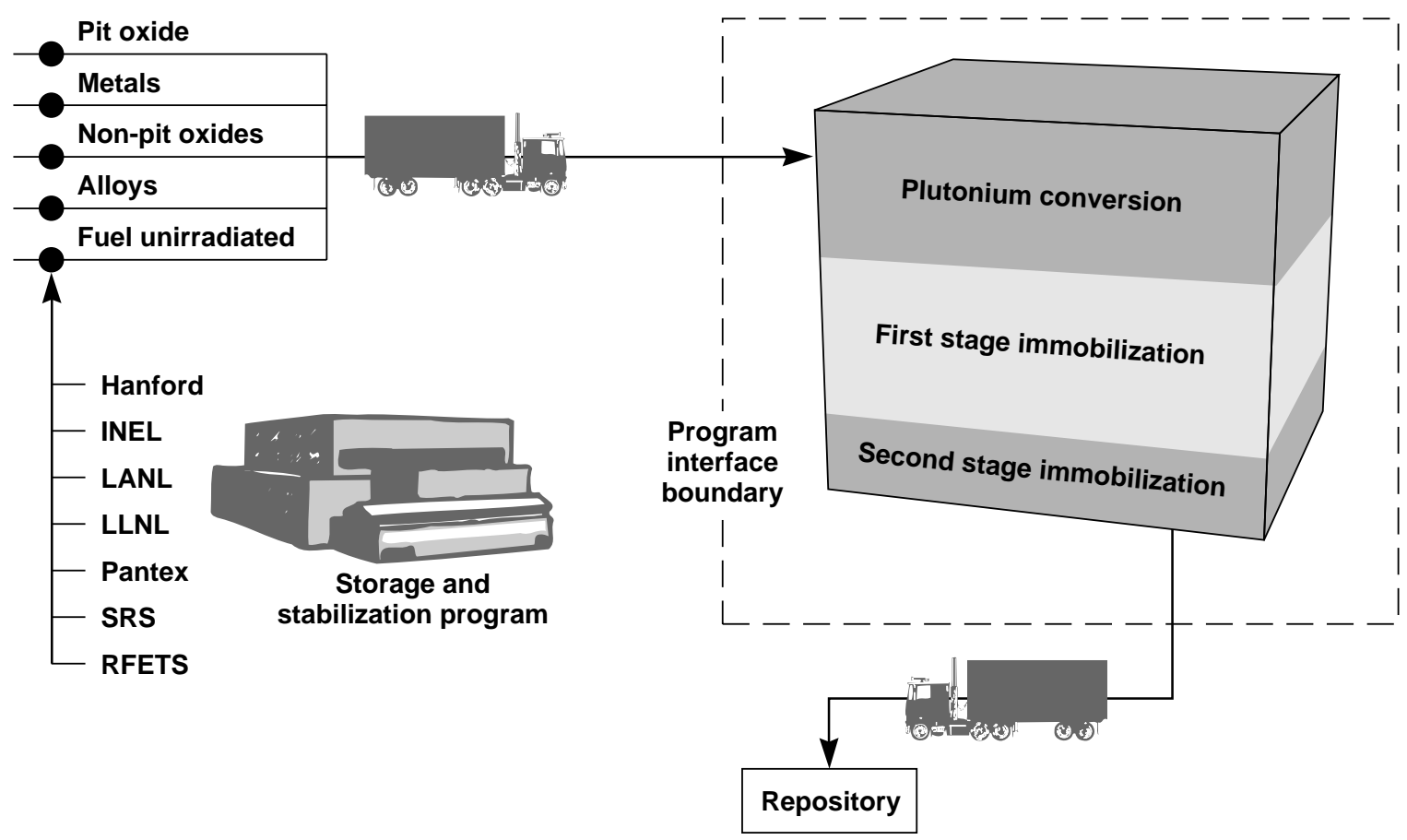

Figure 1-1. Immobilization of surplus fissile materials. 
welded shut. The cans in turn are loaded onto a framework that is placed inside a Defense Waste Processing Facility (DWPF) canister. HLW glass is then poured into the canister at the existing DWPF to form a radiation barrier in the final product. A finished DWPF canister containing the plutonium cans and HLW glass is shown in Figure 1-2. The PIP is located at the Savannah River Site (SRS) and uses new buildings to perform the immobilization mission. The pour of HLW glass is performed at the existing DWPF.

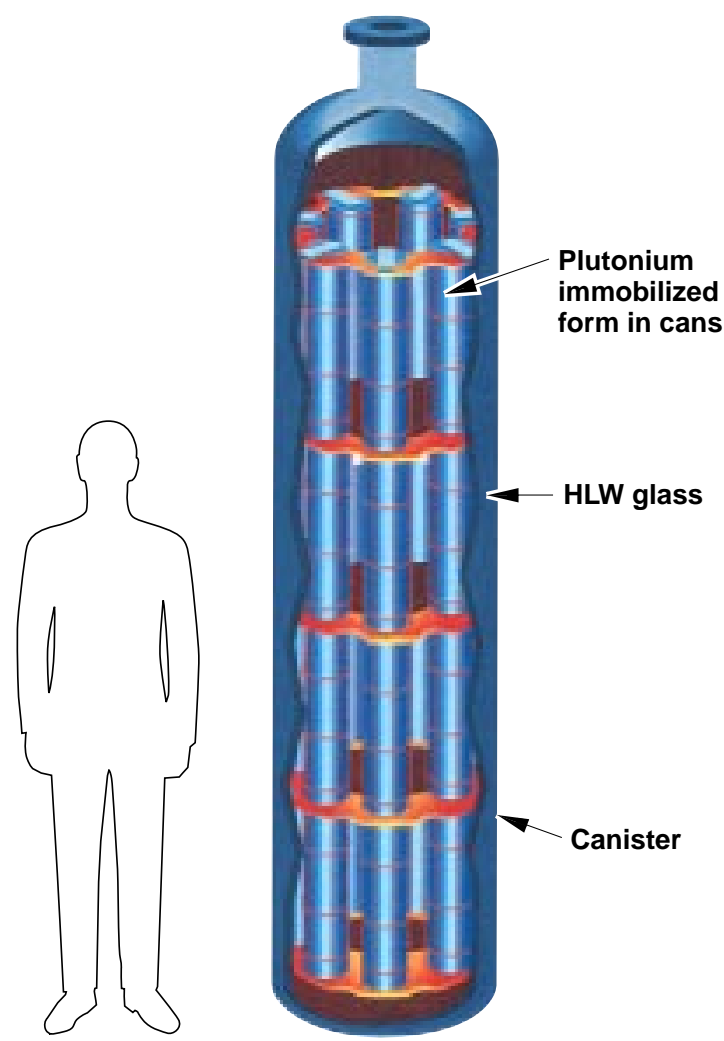

Figure 1-2. Nominal can-in-canister design.

\subsubsection{Immobilization}

Immobilization is the fixation of the surplus plutonium in an acceptable matrix to create an environmentally benign form for disposal in an HLW repository. In addition to the traditional characteristics required of an immobilization form to achieve isolation of the fissile material from the biosphere over geologic times, the immobilization form for the Materials Disposition (MD) Program must also possess the property that it is inherently as unattractive and inaccessible as the fissile material from spent fuel. The starting point for this latter requirement is part of the so-called "spent fuel standard" invoked in the National Academy of Sciences (NAS) study on plutonium disposition. From this perspective, HLW or other radioactive species, such as ${ }^{137} \mathrm{Cs}$, can be added with the plutonium in the immobilized form to 
create a radiation field that can serve as a proliferation deterrent. For the can-incanister option, the radiation field is created by HLW glass poured into the canister from the DWPF vitrification system.

\subsubsection{Glass Immobilization Form}

In several countries, including the United States, radioactive HLW is mixed with molten glass and poured in a process known as vitrification, producing highly radioactive glass "logs" to be stored for an interim period and then buried in repositories. Vitrification plants are or have been in operation in several countries including France, the United Kingdom, Germany, Belgium, Japan, and the United States. Borosilicate glass was chosen as the waste form for virtually all HLW in the western world because it combines the qualities of high waste solubility, high tolerance to waste variability, adequate leach resistance, and high thermal and radiation stability.

Borosilicate glass is an amorphous material formed by melting a combination of silicon, boron, and other oxides. The oxides and their relative amounts are selected primarily to maximize radionuclide solubility and glass durability, minimize melting temperature, and achieve a proper viscosity for pouring. Common additives to this "frit" are alkalis, alkaline earths, and alumina. The frit is mixed with the HLW material and turned into glass in a melter.

The LaBS glass currently under development for plutonium disposition contains $\mathrm{SiO}_{2}, \mathrm{Al}_{2} \mathrm{O}_{3}, \mathrm{~B}_{2} \mathrm{O}_{3}, \mathrm{HfO}_{2}$, oxides of rare earth elements (REE), $\mathrm{SrO}$, and $\mathrm{PuO}_{2}$. Hafnium and gadolinium (one of the REEs in the glass) are added to serve as neutron absorbers to avoid criticality at high plutonium loadings. The relative amounts of the LaBS frit components are adjusted to also allow adequate solubilities of elements such as uranium, calcium, magnesium, iron, chromium, nickel, and others contained in the impure plutonium feed materials. Current research and development now indicates that $8 \%$ plutonium by weight is appropriate for incorporation into LaBS glass. Plutonium is believed to enter the random network structure of the LaBS glass in sixfold coordinated sites, where it is bonded to six oxygens. Therefore plutonium forms an integral part of the glass structure. It cannot be removed or preferentially leached from the glass without corresponding degradation of the local glass structure.

The current LaBS glass formulation has a durability about 10 times greater than the HLW glass in production at the DWPF. In addition, even when leached from a glassy matrix, the very low solubility of plutonium causes it to be released at a much slower rate than that at which the glass matrix reacts. Generally the rates of plutonium release are much less than $10 \%$ of the glass matrix reaction rate. 


\subsection{Assumptions and Design Basis}

\subsubsection{Program Assumptions}

The following assumptions have been used to develop the flowsheets, block flow diagrams, chemical input and output, etc. for the glass immobilization option.

- The immobilization facility shall receive plutonium in the form of oxides from pits, materials resulting from the Defense Nuclear Facility Safety Board (DNFSB) Recommendations 94-1 Remediation Program, and other surplus plutonium forms (Table 1-1).

- The plutonium feed to the PIP is primarily in the form of clean oxides (including pit oxides), impure metal, plutonium alloys, impure oxides, uranium/plutonium oxides, alloy reactor fuel, and oxide reactor fuel.

- The nominal feed of plutonium over the life of the PIP is 50 metric tonnes $(50,000 \mathrm{~kg}$; 56 tons, 110,000 lb) of plutonium.

- A second scenario for the PIP is to share the processing of the 50 tonnes (56 tons) of material with a mixed oxide fuel (MOX)/reactor disposition option. This case, in which immobilization will process 18.2 tonnes (20.1 tons) (the nominal 17 tonne case) in 10 years, is treated in the Appendix A.

- There are studies currently being performed to evaluate cost reduction initiatives by accelerating the shipment of feed materials to the PIP. Most of the cases in the evaluation will have little or no impact on the PIP facility design. The receipt of special nuclear material (SNM) at the levels proposed in the study cases are well within the estimate of the PIP receiving function capacity of 2400 units per year. One of the proposed shipping scenarios will require some marginal, additional storage space in the receiving vault. However, the required additional resources are within the estimated resource requirements for both construction and operations.

- The immobilized canister shall contain an added source of radiation in the form of HLW glass to increase its proliferation resistance. The radiation field shall be greater than $0.026 \mathrm{C} / \mathrm{kg} / \mathrm{h}(100 \mathrm{R} / \mathrm{h})$ at $1 \mathrm{~m}(3 \mathrm{ft})$ from the package surface 30 years after initial fabrication.

- The plutonium material loading in the glass immobilized form is a design parameter involving multiple tradeoffs. The nominal loading for this study is about $8 \%$ plutonium (by weight).

- The immobilization canister will be the same as that used for the DWPF. 
- Criticality considerations shall explicitly address both the immobilization processing/form fabrication with associated equipment (off-gas treatment, etc.) and repository storage for thousands of years into the future. The preferred criticality control during immobilization processing is by batch mass control or equipment geometry. The use of neutron absorbers (e.g., gadolinium, samarium, hafnium, boron, etc.) shall be considered for repository criticality control. Criticality design issues within this report are based on preliminary criticality calculations, engineering judgments, and extrapolation from similar processes.

Table 1-1. Feed materials to PIP.

\begin{tabular}{|c|c|}
\hline Feed projection categories & $\begin{array}{c}\text { Plutonium mass, } \\
\text { tonne (ton) }\end{array}$ \\
\hline Clean oxides (including pits) & $33.5(36.9)$ \\
\hline Impure metal & $3.4(3.7)$ \\
\hline Plutonium alloys & $1.0(1.1)$ \\
\hline Impure oxides & $6.4(7.1)$ \\
\hline Uranium/plutonium oxides & $0.9(1.0)$ \\
\hline Alloy reactor fuel & $3.5(3.9)$ \\
\hline Oxide reactor fuel & $1.3(1.4)$ \\
\hline Total & $50.0(56)$ \\
\hline
\end{tabular}

\subsubsection{PIP Assumptions and Design Basis}

The following assumptions have been used to develop the PIP using new buildings at SRS:

- The PIP is located in a new building at the SRS.

- The PIP will include converting the plutonium feed materials to $\mathrm{PuO}_{2} / \mathrm{UO}_{\mathrm{x}}$, immobilizing of the $\mathrm{PuO}_{2} / \mathrm{UO}_{\mathrm{x}}$ in glass, pouring the glass into steel cans, and loading the cans into DWPF canisters.

- HLW glass will be poured into the canister at the existing DWPF.

- The general design basis document used in the design of the PIP is Department of Energy (DOE) Order 6430.1A, General Design Criteria. While it is recognized that this facility may be licensed by the Nuclear Regulatory Commission (NRC) and that a series of new DOE orders have and are being issued that supersede DOE Order 6430.1A, the design criteria guidance and 
requirements contained in DOE Order 6430.1A form the basis for the preconceptual PIP design. DOE Order 6430.1A covers design criteria, including applicable regulatory and industry codes and standards for the design of DOE nonreactor facilities. This order includes design criteria for both conventional facilities designed to industrial standards and "special facilities" (defined as nonreactor nuclear facilities and explosive facilities).

- Conventional design codes and standards have been used for the design basis of the non-nuclear facilities in the PIP, including the following:

- Administrative building

- Support utilities building

- Warehouse

- Shops and equipment mockup building

- Industrial waste treatment building

- Sanitary waste treatment building

- Cold chemical storage building

- Facility cooling tower

- Training center - H area

- Facility guardhouses.

- Design codes and standards applicable to "special facilities" as defined in DOE Order 6430.1A apply to the following:

- Plutonium processing building

- DWPF

- Glass Waste Storage Building (GWSB)

- Radwaste management building

- Hot maintenance facility

\subsubsection{Facility Capacity/Capability}

The PIP will have a 10-year production mission. The facility will process plutonium metal and oxide at a rate of 5 tonnes (5.6 tons) of plutonium per year. A 10 -year mission is a conservative assumption. The actual production mission time will be optimized to maximum production at minimum duration. 
Operations shall be three shifts per day, seven days per week. The PIP is assumed to operate with an availability factor of $75 \%$. Allowing normal time for maintenance, accountability, criticality control, etc., normal operations shall be considered to be a 200-day production year. Nominal throughput shall, therefore, be $8.34 \mathrm{~kg}(18 \mathrm{lb})$ of plutonium per eight-hour shift.

Full interim on-site storage capacity will be provided for finished plutoniumglass canisters filled with HLW glass that will be produced during the operating mission. Each plutonium-glass canister will measure $60 \mathrm{~cm}(24 \mathrm{in})$ in diameter by $3 \mathrm{~m}$ (120 in) high, and weigh approximately 2,490 kg (5,480 lb). Each canister is anticipated to contain $26.3 \mathrm{~kg}$ ( $58 \mathrm{lb}$ ) of plutonium, and approximately 190 canisters will be required to handle 5 tonnes (5.6 tons) of plutonium per year. Based on processing 50 tonnes (56 tons) in 10 years, a total of approximately 1900 canisters are needed for the complete project. This results in 340 additional canisters over that expected for the HLW Vitrification Program.

\subsubsection{Facility Operating Basis}

The PIP is assumed to be operated with DNFSB oversight in conformance with DOE orders. However the plant will be prepared to shift to Nuclear Regulatory Commission (NRC) regulations if required. The schedule (Table 1-2) indicates preliminary design and preparation of a license application beginning in 1999. Licensing is estimated to require five years. Construction is assumed to start in the second quarter of 2001. During the licensing period, final design is completed. Construction, start-up, preoperational testing, and operational readiness review are estimated to require about four years. Operations are assumed to start about 2005 and be completed in 2015, for a nominal ten year operating period. Deactivation and decontamination $(D \& D)$ of the facilities is estimated to require about three years, resulting in an overall program completion date of 2019.

A capital project will be required to implement the plutonium immobilization alternative. An assumption is that DOE line-item projects will be conducted in accordance with DOE orders and the congressional funding cycle.

A research, development, and testing (RD\&T) program has been identified to develop and demonstrate the process and equipment and to qualify the immobilized product. This RD\&T program began in 1995 and continues through 2002.

National Environmental Protection Act (NEPA) activities are included. An Environmental Impact Statement (EIS) with a preferred site and evaluation of alternatives will be submitted by DOE for the NEPA approvals. 
Table 1-2. Facility schedule.

\begin{tabular}{|l|c|c|}
\hline \multirow{2}{*}{\multicolumn{1}{|c|}{ Activity }} & \multicolumn{2}{c|}{ Calendar year } \\
\cline { 2 - 3 } & Beginning & End \\
\hline Research and development & 1995 & 2002 \\
\hline Integrated process demonstrations & 1997 & 2003 \\
\hline Design and construction phases & 1999 & 2004 \\
\hline Permitting/licensing phase & 1999 & 2004 \\
\hline Start-up and operation phase & 2004 & 2015 \\
\hline D\&D and/or conversion phase & 2016 & 2019 \\
\hline
\end{tabular}

Preparation of a Safety Analysis Report (SAR) is included during preliminary and final design. Construction, procurement, cold start-up, and preoperational testing of the facility will be followed by hot start-up and operations.

Deactivation and decontamination will follow operations, in about the year 2016. The decommissioning method assumed for the schedule is decontamination to levels that permit unrestricted reuse of the facility. Other methods (layaway, protective storage, etc.) or combinations of methods, depending on time, cost benefit studies, or radiation exposure, might be selected with an impact on the time required.

1.2.4.1 Research, Development, and Testing Basis. The duration and scope of the research, development, and testing program must be sufficient to develop and demonstrate the immobilization processes and to assess the durability and performance of the immobilized product. The bulk of the RD\&T would occur between the site selection Record of Decision (ROD) and the end of the preliminary design. The primary research, development, and testing tasks will be required to:

- Confirm and document the nuclear criticality safety margins of every stage of plutonium handling and processing

- Define the chemical and physical properties of the immobilized plutonium form, including its stability and leachability in a repository environment

- Develop and demonstrate acceptable performance of new equipment, processes, and operating procedures.

1.2.4.2 Permitting/Licensing Basis. Feed conversion and glass immobilization of plutonium in the PIP will require compliance with applicable laws, regulations, executive orders, DOE orders, and, possibly, NRC regulations. This section identifies the major regulatory requirements that must be addressed. 
Where specific design criteria for nuclear facilities are not provided by the new DOE orders, the design criteria for nuclear facilities will follow the guidance and requirements provided in DOE Order 6430.1A. More specific criteria can be found in Division 13, "Special Facilities": Sections 1300, "General Requirements"; 1304, "Plutonium Processing and Handling Facilities"; 1305, "Plutonium Storage Facilities"; 1323, "Radioactive Liquid Waste Facilities"; 1324, "Radioactive Solid Waste Facilities"; and 1325, "Laboratory Facilities."

1.2.4.3 Construction Basis. A capital project will be required to implement this plutonium immobilization alternative, which includes the construction of a new building. The DOE line item projects must be conducted in accordance with DOE orders and the congressional funding cycle. A conceptual design and preliminary cost estimate will be developed for DOE validation.

Critical decisions for approval of preliminary design, commencing construction, and commencing operations will be made by the DOE in support of this plutonium immobilization alternative.

\subsubsection{Compliance}

1.2.5.1 Rules, Regulations, Codes, and Guidelines. Basic references concerning the content and procedures for issuing an EIS can be found in the Council on Environmental Quality Regulation in the Code of Federal Regulations (CFR) 40CFR1502, Environmental Impact Statement; 10CFR1021, National Environmental Policy Act Implementing Procedures (for DOE); and DOE Orders 5400.1, General Environmental Protection Program, and 5440.1E, National Environmental Policy Act Compliance Program.

Applicable NRC regulatory guides referenced in DOE Order 6430.1A will be used. New DOE orders, as appropriate, will supersede the orders referenced when implemented by the SRS site. Table 1-3 presents a listing of some of the DOE orders canceled or partially canceled and the replacement DOE orders.

1.2.5.2 Safeguards and Security. The basic compliance document for safeguards and security requirements for the facility design is DOE Order 6430.1A, General Design Criteria, Section 1300-10, and the 5630 series of DOE orders.

1.2.5.3 Environmental, Safety, and Health (ES\&H). ES\&H requirements will generally follow DOE Order 5480.4, Environmental, Safety, and Health Protection Standards; DOE Order 5480.1B, Environmental, Safety, and Health Program for DOE Operations; and DOE Order 5440.1C, National Environmental Policy Act.

Requirements for the facility fire protection systems will be in accordance with DOE Order 5480.7A, Fire Protection. Criticality safety will follow DOE Order 5480.24, which endorses American National Standards Institute (ANSI)/American Nuclear Society (ANS) Standards 8.1, 8.3, 8.5, 8.7, 8.15, and 8.19, with exceptions. 
UCRL-ID-128271

Table 1-3. Crosswalk: Partial listing of canceled DOE orders to new DOE orders (as of 8/97).

\begin{tabular}{|c|c|c|}
\hline $\begin{array}{c}\text { Canceled/partially canceled DOE } \\
\text { orders/standards }\end{array}$ & Replacement DOE order/standard & Notes \\
\hline 6430.1A - General Design Criteria & $\begin{array}{l}420.1 \text { - Facility Safety } \\
430.1 \text { - Life-Cycle Asset Management }\end{array}$ & $\begin{array}{l}420.1 \text { cancels only Division } 13 \text { of } 6430.1 \mathrm{~A} \\
430 \text { cancels all of } 6430.1 \mathrm{~A}\end{array}$ \\
\hline *5400.1 - General Environmental Protections Program & 231.1 - Environment, Safety, and Health Reporting & $\begin{array}{l}231.1 \text { cancels paras. } 2 \mathrm{~B}, 4 \mathrm{~B} \text {, and } 4 \mathrm{C} \text { of Chapter II } \\
\text { and paras. } 2 \mathrm{D} \text { and } 3 \mathrm{~B} \text { of } \mathrm{Chapter} \mathrm{III}\end{array}$ \\
\hline $\begin{array}{l}\text { 5440.1E - National Environmental Policy Act } \\
\text { Compliance Program }\end{array}$ & $\begin{array}{l}\text { 231.1 - Environment, Safety, and Health Reporting } \\
\text { 451.1A - National Environmental Policy Act } \\
\text { Compliance Program } \\
\text { 10CFR1021 - DOE NEPA Implementing Procedures }\end{array}$ & \\
\hline $\begin{array}{l}* 5480.4 \text { - Environment Protection, Safety, and Health } \\
\text { Protection Standards }\end{array}$ & $\begin{array}{l}440.1 \text { - Worker Protection Management for DOE } \\
\text { Federal and Contractor Employees }\end{array}$ & $\begin{array}{l}440.1 \text { cancels Attachment 2, paras. 2C, 2D(2)-(3), } \\
\text { 2E(1)-(8) and Attachment 3, paras. 2C, 2D(2)-(3), } \\
2 \mathrm{E}(1)-(7)\end{array}$ \\
\hline $\begin{array}{l}\text { *5480.1B - Environment, Safety, and Health Program } \\
\text { for DOE Operations }\end{array}$ & 5480.21 - Unreviewed Safety Questions & 5480.21 cancels para. 5.0 . \\
\hline 5480.7A - Fire Protection & 420.1 - Facility Safety & \\
\hline 5480.24 - Criticality Safety & 420.1 - Facility Safety & \\
\hline 5480.28 - Natural Phenomena Hazards Mitigation & $\begin{array}{l}420.1 \text { - Facility Safety } \\
\text { DOE-STD-1020-94, 1021-93, 1022-94, 1023-95, } \\
1024-92\end{array}$ & \\
\hline *5481.1B - Safety Analysis and Review System & 5480.23 - Nuclear Safety Analysis Reports & 5480.23 cancels $5481.1 \mathrm{~B}$ for nuclear facilities. \\
\hline 4330.4B - Maintenance Management Program & 10CFR830.340 - Maintenance Management & $\begin{array}{l}\text { 10CFR } 830.340 \text { will replace } 4330.4 \mathrm{~B} \text { when } \\
\text { promulgated }\end{array}$ \\
\hline DOE-STD-3005-YR & None. & $\begin{array}{l}\text { DOE-STD-3005-YR was never issued in final, only } \\
\text { draft }\end{array}$ \\
\hline
\end{tabular}

*Order is partially canceled 
1.2.5.4 Buffer Zones. In general, siting criteria will follow DOE Order 6430.1A, Sections 0200-1, "Facility Siting"; 0200-2, "Building Location"; and 0200-99, "Special Facilities." Effluent releases will not exceed limits referenced in DOE Order 5400.1, General Environmental Protection Program Requirements; the directive on Radiation Protection of the Public and the Environment in the DOE 5400 series of orders; and DOE Order 6430.1A, Section 1300-9, "Effluent Control and Monitoring."

1.2.5.5 Deactivation and Decontamination. Design requirements for D\&D for the facility will be in accordance with DOE Order 6430.1A, Section 1300-11, "Deactivation and Decontamination (of Special Facilities)"; Section 1304-8, "D\&D of Plutonium Processing and Handling Facilities"; and Section 1325-6, "D\&D of Laboratory Facilities."

1.2.5.6 Non-Safety/Safety Class Systems, Components, and Structures. Nonsafety class systems, components, and structures will be designed to normal industrial standards. Non-safety class structures will be designed to the International Conference of Building Materials Uniform Building Code (UBC). Non-safety class electrical systems and components will be designed to appropriate Institute of Electrical and Electronic Engineers (IEEE) standards. Other non-safety class systems and components will be designed to appropriate industrial standards.

Safety class systems, components, and structures will be designed to the requirements of DOE Order 6430.1A, Sections 1300-3, "Safety Class Criteria," and 1300-4, "Nuclear Criticality Safety."

The facility safety analysis and risk assessment will comply with DOE Orders 5480.23, Nuclear Safety Analysis Reports, and 5481.1B, Safety Analysis and Review System; and with DOE Order 6430.1A, Section 0110-5.2, "Safety Analysis."

Design basis natural phenomena (i.e., design basis earthquake, design basis tornado, and design basis flood) will be chosen in accordance with DOE-STD-1020-94, Design and Evaluation Guidelines for DOE Facilities Subject to Natural Phenomena Hazards.

1.2.5.7 Toxicological/Radiological Exposure. Exposures to hazardous effluents (both radioactive and nonradioactive) will not exceed the limits referenced in DOE Order 5400.1 and the directive on Radiation Protection of the Public and the Environment in the DOE 5400 series of orders. Effluent control and monitoring will be in accordance with DOE Order 6430.1A, Section 1300-9, "Effluent Control and Monitoring (of Special Facilities)."

1.2.5.8 Waste Management. Waste management systems provided for the facility will be in accordance with the requirements of DOE Order 6430.1A, Section 1300-8, "Waste Management (for Special Facilities)"; Section 1304-7, "Effluent Control and Monitoring (of Plutonium Processing and Handling Facilities)"; 
Section 1305-6, "Effluent Control and Monitoring (of Plutonium Storage Facilities)"; and Section 1324-7, "Effluent Control and Monitoring (of Radioactive Solid Waste Facilities)."

Specific DOE design and operating requirements for radioactive wastes (including low level waste [LLW] and transuranic [TRU] waste) appear in DOE Order 5820.2A, Radioactive Waste Management. Nonradioactive, hazardous waste requirements appear in DOE Order 5480.1B and applicable sections of 40CFR264, 265, 267, and 268. A DOE pollution prevention program (including waste minimization; source reduction; and recycling of solid, liquid, and air emissions) will be implemented in accordance with DOE Orders 5400.1, General Environmental Protection Program, and 5820.2A, Environmental Compliance Issue Coordination. 


\subsection{Plutonium Immobilization Plant Facility Description}

\subsection{General Facility Description}

\subsubsection{Functional Description}

In the PIP, plutonium materials from DOE's sites are first received and processed physically and chemically in the plutonium conversion portion of the plant to provide an oxide form. In the first-stage of the immobilization process, the plutonium oxide is incorporated into glass which is poured into individual cans. In the second-stage of the immobilization process, a number of cans are mounted on a rack in a DWPF canister and the canisters are filled with HLW glass at the DWPF. The filled canisters are then stored in the GWSB while waiting for final disposition in a repository. A new process building for conversion and immobilization processing will be constructed adjacent to the Actinide Packaging and Storage Facility (APSF) currently being constructed in F-Area at the Savannah River Site. The APSF and the existing DWPF at the SRS will also be utilized for the end-to-end immobilization operations.

The PIP provides the following functional areas:

- Shipping and receiving

- Material management

- Plutonium conversion

- Glass processing

- Canister loading.

Waste management and other necessary facility infrastructure and utility support functions are required to support the primary process operations.

Figure 2-1 is a facility flow diagram which depicts the major processes included in the PIP and the DWPF.

\subsubsection{Plot Plan}

The plutonium immobilization operations site will be located inside the existing F-Area, H-Area, and S-Area at SRS. All of the structures and buildings required to receive, process, and store feed materials and the final product will be provided on the site. A PIP conceptual plot plan is shown in Figure 2-2. The plot plan indicates 


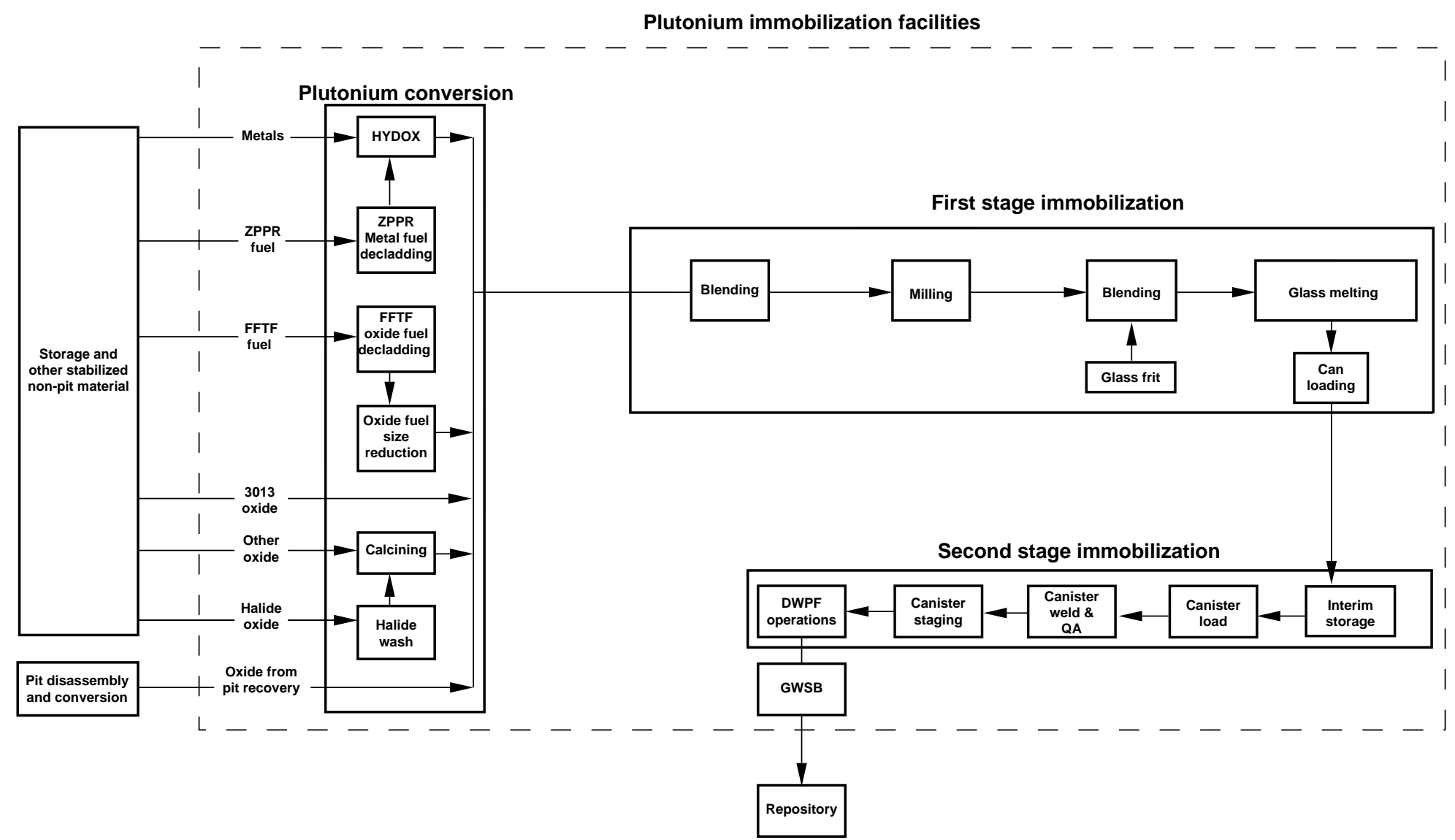

Figure 2-1. Plutonium immobilization facilities flow diagram. 


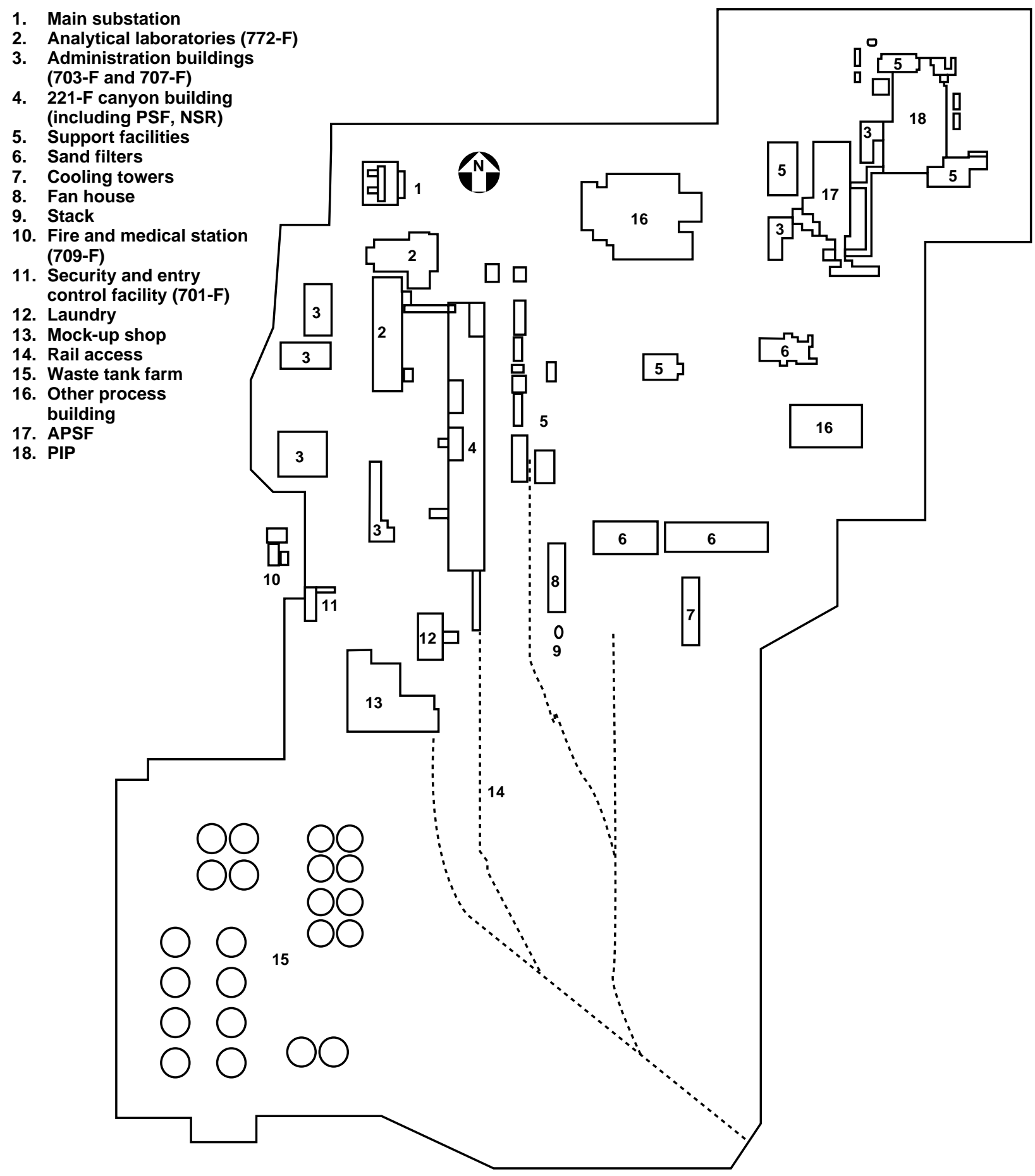

Figure 2-2. F-Area plot plan for Plutonium Immobilization Plant (PIP). 
the general layout of the facilities for the purpose of establishing area requirements, safeguards and security components, and support function locations. The design of facility buildings is at the preconceptual level and can change as the design matures.

The major structures on the site for plutonium immobilization processing include the following:

- Main process building (PIP, F-Area, new)

- $\operatorname{APSF}(F-A r e a$, new)

- DWPF (S-Area, existing)

- GWSB (S-Area, existing)

Support and service facilities for the PIP include the following:

- Administrative buildings (Buildings 703-F and 707-F in F-Area, existing)

- Analytical laboratory (Building 772-F in F-Area, existing)

- Security and entry control facility (Building 701-F in F-Area, existing)

- Fire and medical station (Building 709-F in F-Area, existing)

- Cooling tower (F-Area, existing)

- Steam boiler (D-Area, existing).

In addition, SRS waste management facilities to support the immobilization operations include the following:

- SRS TRU Facility (planned)

- TRU waste storage pad (E-Area, existing)

- Consolidated incineration facility (CIF) (Building 261-H in H-Area, existing)

- SRS hazardous/mixed waste disposal facility (planned)

- Mixed waste storage area (643-29E in E-Area, existing)

- LLW storage vault (643-7E in E-Area, existing)

- Hazardous waste storage facility (N-Area, existing)

- Effluent treatment facility (H-Area, existing)

- Radioactive liquid waste storage tanks (241-F in F-Area, existing)

- Central sanitary wastewater treatment facility (C-Area, existing). 


\subsubsection{Building Descriptions}

The PIP includes the following planned and existing major structures to provide the space and equipment necessary to perform the required functions:

- New main process building for plutonium conversion and immobilization and canister loading

- APSF currently being constructed for receiving, storage, unpackaging, and accountability measurements

- DWPF for receipt of loaded canisters and transfer to the DWPF melt cell and HLW fill operations.

Facility data is summarized in Table 2-1, and the buildings are described in more detail in the following subsections.

Table 2-1. Plutonium conversion and immobilization facility data.

\begin{tabular}{|c|c|c|c|c|}
\hline Building/structure & $\begin{array}{c}\text { Area, } \\
\mathrm{m}^{2}\left(\mathrm{ft}^{2}\right)\end{array}$ & $\begin{array}{l}\text { Number } \\
\text { of levels }\end{array}$ & $\begin{array}{c}\text { Special } \\
\text { materials }\end{array}$ & $\begin{array}{c}\text { Construction } \\
\text { type }\end{array}$ \\
\hline Process Buildings: & $8,300(88,900)$ & & & \\
\hline APSF & $977(10,515)$ & 1 & SNM & Concrete \\
\hline New construction & $5,425(58,400)$ & 3 & SNM & Concrete \\
\hline Analytical laboratories & $1,858(20,000)$ & 2 & SNM & Concrete \\
\hline Administrative Facilities: & $1,925(20,721)$ & 2 & $\begin{array}{c}\text { None } \\
\text { identified }\end{array}$ & $\begin{array}{c}\text { Concrete/ } \\
\text { metal }\end{array}$ \\
\hline Utilities: & $2,786(29,989)$ & 3 & $\begin{array}{c}\text { None } \\
\text { identified }\end{array}$ & $\begin{array}{c}\text { Concrete/ } \\
\text { metal }\end{array}$ \\
\hline Total & $13,000(140,000)$ & N/A & N/A & N/A \\
\hline
\end{tabular}

Notes:

- Minor modifications to DWPF loading dock are not included here.

- Analytical laboratory consists of space allotted from existing laboratories.

- Other existing facilities such as fire station, waste storage, etc. will be used.

2.1.3.1 Plutonium Processing Building. The new plutonium processing building (Figure 2-3) will be constructed adjacent to the APSF. The strategy of locating the plutonium processing building adjacent to the APSF allows the use of the SNM receiving and storage capabilities of the APSF, thereby eliminating the need to duplicate these functions within the PIP. Major process operations to be performed in the plutonium processing building include plutonium oxide conversion, glass immobilization, and canister loading. 


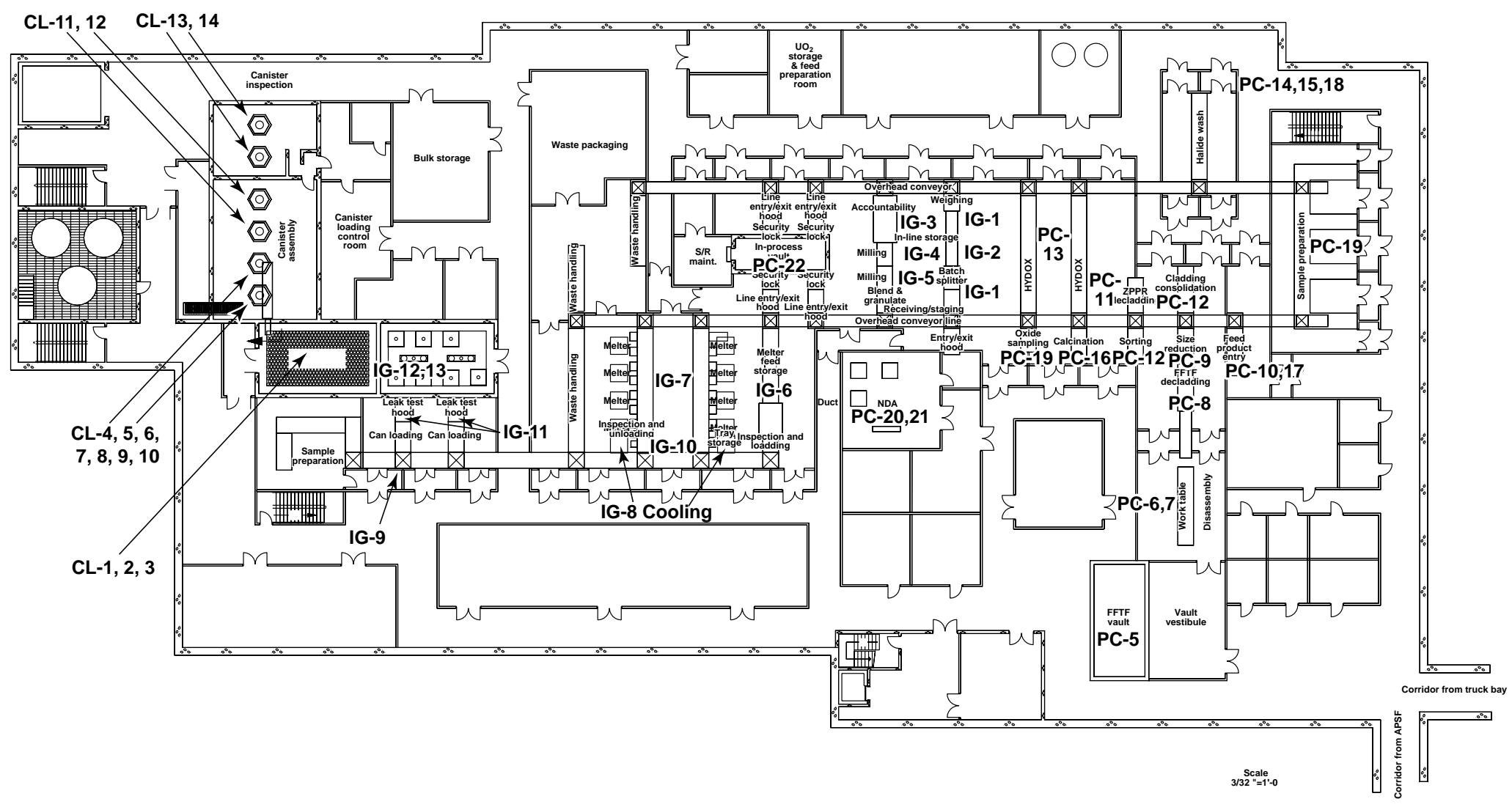

Figure 2-3. Plutonium processing building layout - main process level. 
All feed material receipts will be made through the APSF truck bay. After unloading, unpackaging, and accountability measurement, cans will placed in storage at the APSF. Fast Flux Test Facility (FFTF) fuel assemblies and pins will be delivered directly to the FFTF storage vault in the main process building. Depending on the feed material form, the material will be processed either through Zero Power Physics Reactor (ZPPR) fuel decladding, FFTF fuel pellet grinding, oxide calcination, or hydride/oxidation (HYDOX). The FFTF fuel assemblies and pins will be disassembled and declad in the main process building. Material requiring processing through the halide wash process will be introduced directly to the halide wash glovebox. All other material will be introduced at the head end of the conversion processing line via a product entry glovebox.

The conversion glovebox lines, as well as the other processing lines, will incorporate maintenance and operating sides to minimize production downtime and operator exposure due to maintenance. The conversion processing lines will be serviced by two overhead conveyor lines. These overhead conveyors can be used at any time during processing to retrieve or store material in the in-process storage vault. The in-process storage vault will be serviced by an automated storage/ retrieval (S/R) system. The overhead conveyors can also be used at any time during processing to deliver to the batch splitter, to the accountability operations, to the grinding mills, or to the head end of the immobilization line.

The immobilization line begins with a blending step. It will be serviced by one of the overhead conveyors in the conversion line and by an additional, third, conveyor. The third overhead conveyor is used primarily to transport glass in cans to the load-out gloveboxes. All three overhead conveyors service the waste handling gloveboxes that are used for treatment of waste prior to packaging and disposal. Also, all conveyors provide access to a sample preparation area for analytical support of the process line.

The product cans will be loaded out of the glovebox line, smeared to check for contamination, leak-checked, and delivered to the product non-destructive assay (NDA) room or the product vault. Once the product cans have been assayed, they are ready for assembly in the DWPF canister in the canister assembly area (Figure 2-4). Once assembled and satisfactorily inspected, the canisters will be either temporarily stored or immediately loaded into a transport cask for transport to the DWPF for filling with HLW glass.

The balance of the main process building includes space for offices, radiological support, material/freight handling, bulk storage, firewater collection, control rooms, motor control centers, shops, elevated conveyor maintenance rooms, stairwells, and corridors. A basement level will be provided for the canister loading operations and for a pit to contain the fire water collection tanks. The above grade structures 


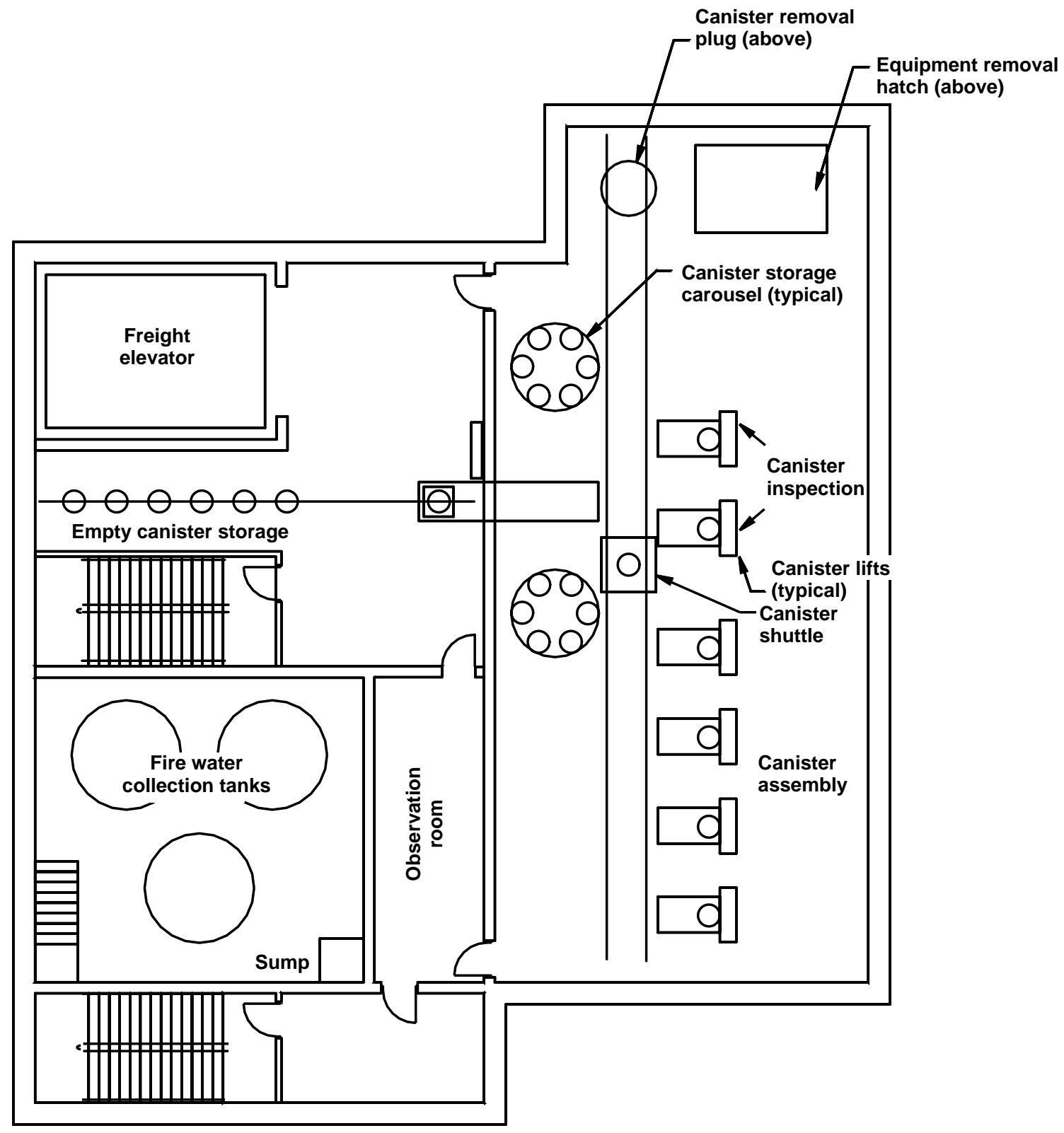

Figure 2-4. Canister assembly area in basement. 
(Figure 2-5) will include the canister loading truck bay, a loading dock for receipt of bulk supplies and removal of waste, process gas storage areas, a ventilation supply building, a ventilation exhaust fan/filter building, an exhaust stack, a compressor building, and an administrative support building. A freight elevator located near the loading dock and canister loading truck bay will service all levels of the immobilization plant.

2.1.3.2 Actinide Packaging and Storage Facility. The APSF (Figure 2-6) is currently being constructed and, when complete, will provide facilities for receiving and storing Category I quantities of SNM. The APSF is a below-grade structure, except the safe, secure transport (SST) truck bay, which is above grade. The APSF contains a package shipping/receiving area, accountability measurement areas, an SNM storage vault, International Atomic Energy Agency (IAEA) inspection area, control/computer rooms, equipment maintenance rooms, and other support facilities. Specific functions of the APSF include SST truck unloading/loading, shipping package storage, material confirmation, shipping package unpackaging, accountability measurements, and storage.

All feed material receipts will be made through the APSF truck bay. All plutonium materials, excluding FFTF fuel assemblies and pins, will be processed through the APSF for confirmatory measurements, unpackaging, non-destructive assay, and storage. The plutonium materials will be introduced to the main process building for processing via a material passageway.

\subsubsection{Defense Waste Processing Facility-Canister Receipt Area. A DWPF} canister containing the plutonium-glass cans will be delivered within a shielded shipping cask to the DWPF staging area. The canister receipt area at DWPF, shown in Figure 2-7, will be modified to receive a canister transport truck. Modifications at DWPF will consist of an extension of the loading area on the east side of Building 210-S. Placement positions will be constructed to minimize multiple handling and to protect the canisters from physical damage and contact with contaminants (i.e., other iron/steel, moisture, etc.) during the short transport period.

The canister will be pressure-tested with dry air or inert gas, leak-checked with helium, and fully inspected at the F-Area departure point. No further testing is required at DWPF. An adequate security force is required during the transport period. 


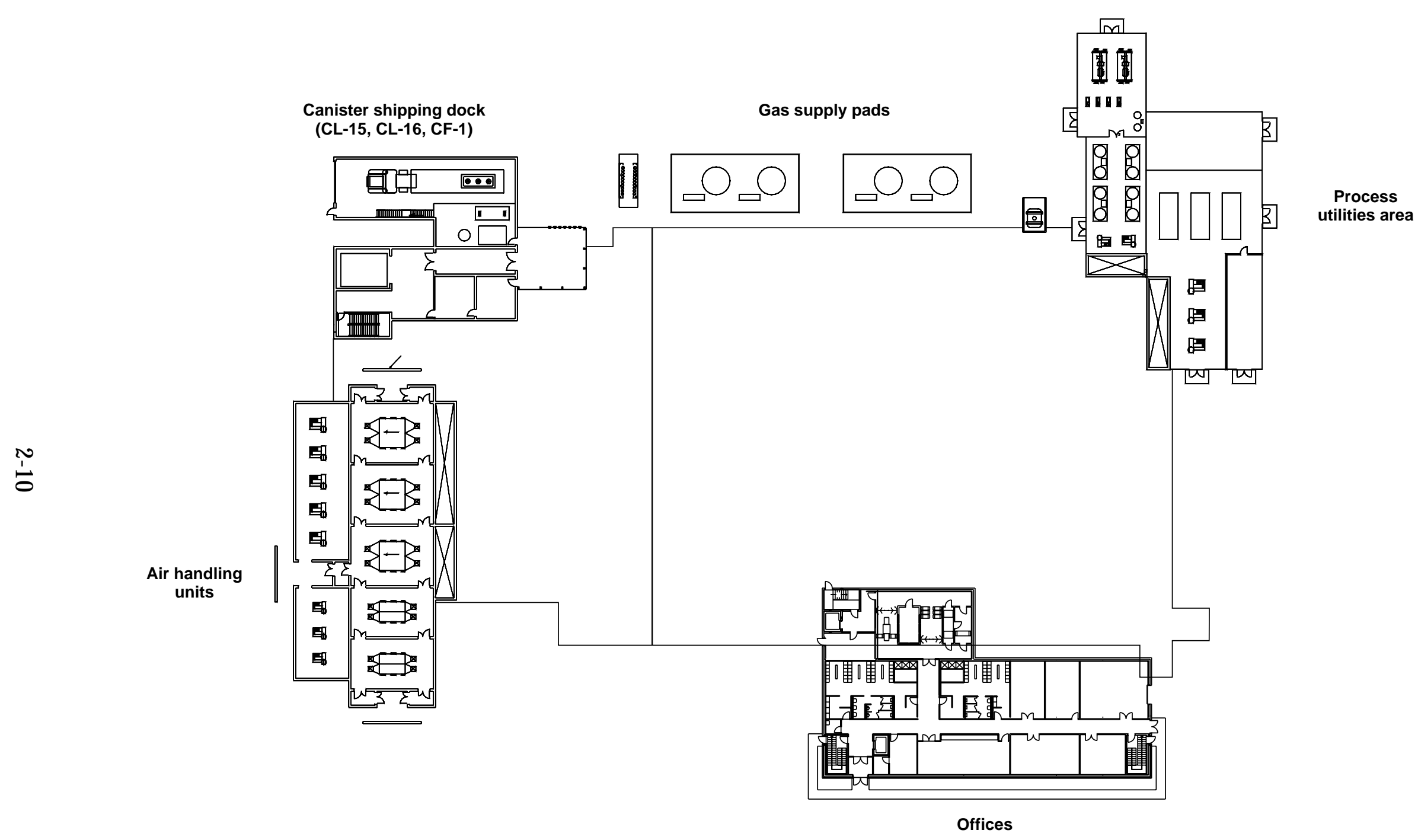

Figure 2-5. Above-grade structures for main process building (PIP). 


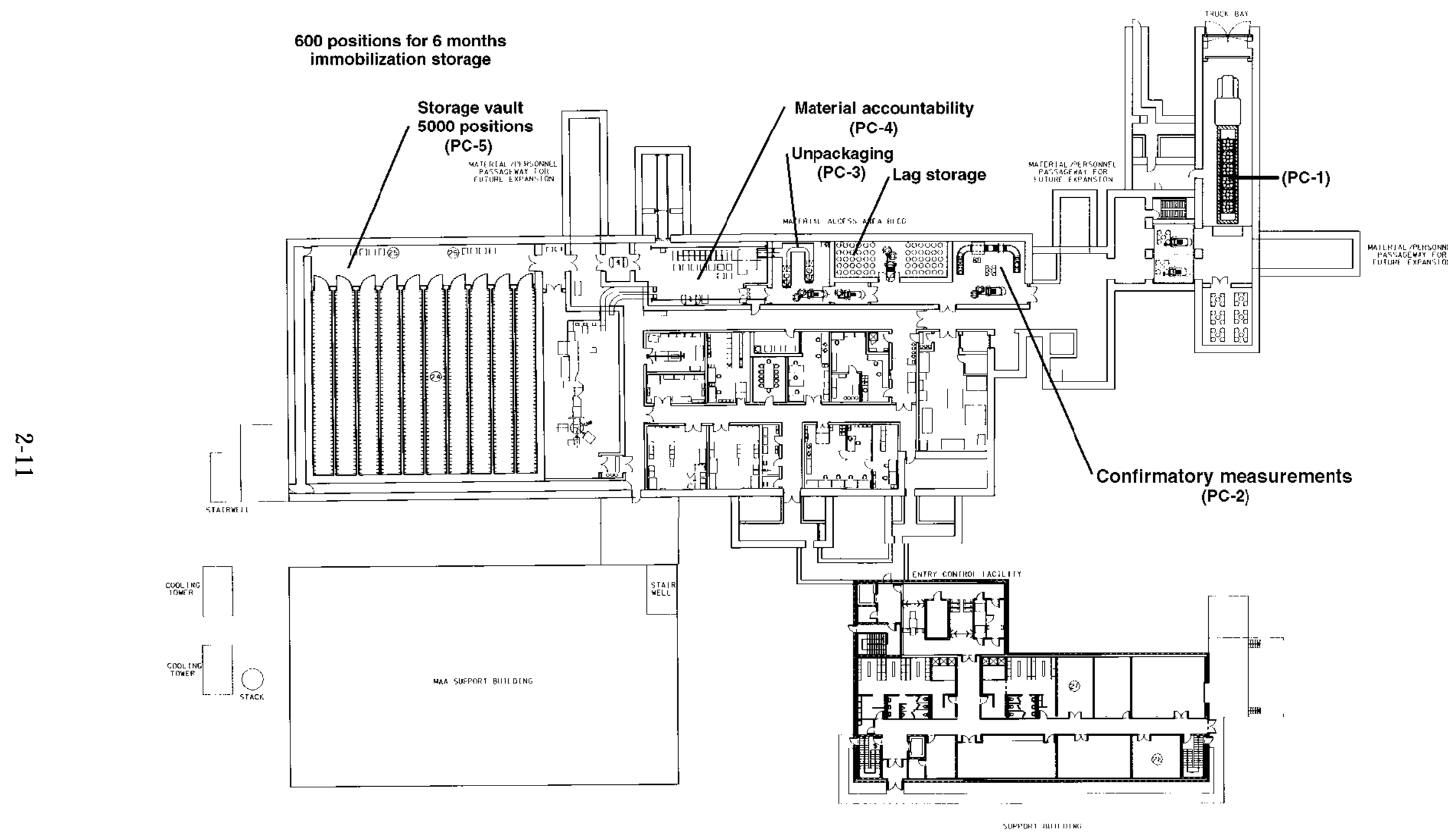

Figure 2-6. Actinide packaging and storage facility. 


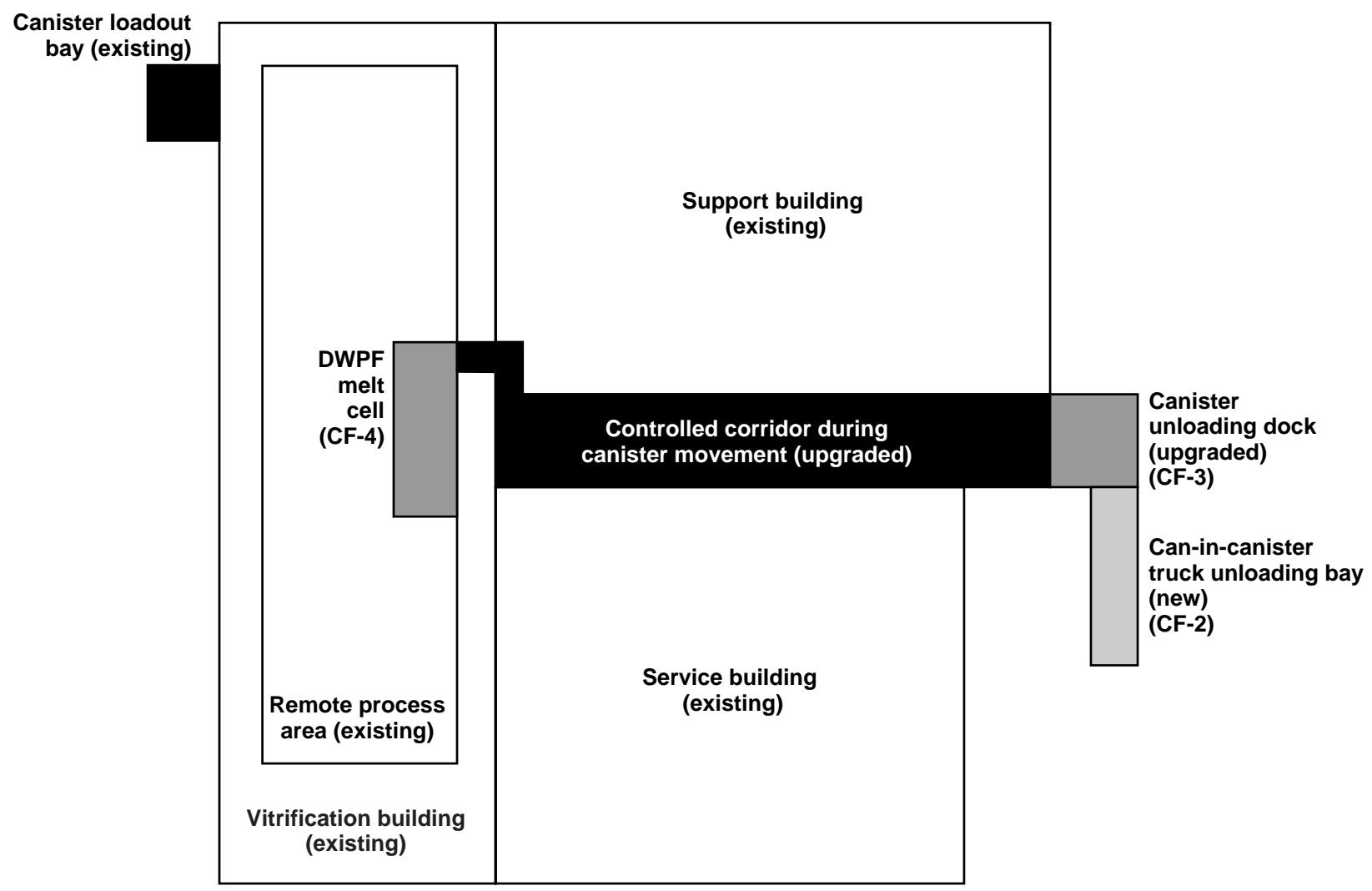

Figure 2-7. Plutonium can-in-canister receipt area at DWPF and transfer route to DWPF melt cell.

Upon receipt at DWPF, the canister will be removed from the transport cask within the newly modified receipt bay. The receipt bay will transport the canister with a heavy duty shielded fork truck from the receipt point through the DWPF canister handling/inspection area to the canister insert hatch in the melt cell.

Security will be maintained by posted sentries sufficient to meet the anticipated security threat until the canister is nested within the rack area of the DWPF melt cell. The canister rack area will be utilized as a transfer staging point for HLW glass filling of the canister. Existing racks will be modified, replaced, or supplemented as required.

With the canister in the melt cell, the transport cask will be cleared from the area and returned to F-Area for reuse. The DWPF transport crane will access and retrieve the canister. The canister will be delivered to the DWPF pour table. Once at the pour table, the canister will immediately be charged with HLW glass per DWPF procedures. The canister will then undergo normal procedures for DWPF canister cleaning, inspection, transport, and storage. 
Once the plutonium-glass canister is filled in the DWPF and returned to canister product storage, it will be treated like all other waste-filled canisters.

2.1.3.4 Waste Treatment Facilities. This section describes the systems and facilities involved in the management of waste. A waste minimization program will be developed that complies with the requirements of DOE Orders 5400.1, General Environmental Protection Program, and 5820.2A, Radioactive Waste Management.

Transuranic Waste. Transuranic solid waste will be packaged in drums and special containers that meet waste acceptance criteria (WAC) for the Waste Isolation Pilot Plant (WIPP). If the waste does not meet the WIPP WAC, it will be packaged in special containers. Waste meeting the WIPP WAC will be assayed and x-rayed and placed in interim storage on TRU waste concrete pads in E-Area. Non-certified waste will be assayed and placed in storage until the SRS TRU Waste Facility becomes operational, at which time the non-certified waste will be repackaged and certified for shipment to WIPP. TRU liquid waste will be stored in the existing F-Area tank farm until processed in DWPF.

Mixed Low Level Waste. Mixed LLW will be placed in drums and transported to permitted storage buildings. The combustible mixed waste will be incinerated at the CIF adjacent to H-Area. The remaining waste will be stored in E-Area concrete vaults until it can be processed in the Hazardous/Mixed Waste Disposal Facility. Ash and blowdown solids from the CIF and treated waste from the Hazardous/Mixed Waste Disposal Facility will be disposed of in hazardous/mixed waste vaults in E-Area.

Liquid Low Level Waste. In general, liquid LLW will not be generated in normal operation.

Solid Low Level Waste. In general, solid LLW will be collected in B-25 $\left(2.5 \mathrm{~m}^{3}\right.$ [90 $\left.\mathrm{ft}^{3}\right]$ ) metal boxes, transported to the LLW Disposal Facility, and disposed of in low-activity waste vaults in E-Area.

High Level Waste. HLW will not be generated by this mission.

Hazardous Waste. Hazardous waste will be placed in drums and transported to permitted storage buildings in the Hazardous Waste Storage Facility in N-Area. Waste that can be incinerated will be shipped to an off-site contractor for treatment/ disposal, typically within a year of generation. The hazardous waste that cannot be incinerated at an off-site facility will be incinerated at the CIF and placed in storage until the Hazardous/Mixed Waste Disposal Facility is operational. At that time, the waste will be dispositioned in hazardous/mixed waste vaults.

Nonhazardous Waste. Sanitary solid waste will be collected and transported to the current SRS sanitary landfill for disposal. The landfill will be monitored for 
30 years after closure through sampling of strategically placed wells. Sanitary liquid waste will be sent to the new SRS Central Sanitary Wastewater Treatment Facility. Coal ash will be disposed of in the landfill. Cooling tower blowdown will be discharged to a permitted outfall to Upper Three Runs Creek.

2.1.3.5 Analytical and Development Laboratories. The primary means for making analytical chemistry determinations involves traditional analytical laboratory measurements. This involves collecting a sample and sending it to the analytical laboratory for analysis. This will require that a sample preparation area be provided in the plutonium area. Small aliquots of sample will be sent to the analytical laboratory either by automatic or manual transfer. The analytical laboratory will contain only small quantities of SNM. Wastes generated in the analytical laboratory will be handled in the existing SRS waste treatment system.

Other existing on-site analytical facilities will be available for back-up and method development purposes.

\subsubsection{Support Facilities}

Administrative and Support Facilities. The administrative and service buildings, each connected to the main process building and the APSF, will provide space for entry control, change rooms, locker rooms, rest rooms, and offices. A support building adjacent to the APSF will provide space for general maintenance shops. Other support facilities include warehouses, a gas cylinder storage shed, and bulk chemical storage.

Support Utilities and Services. Cooling towers, an electrical substation, an emergency diesel generator, and a compressor building will be provided to support the immobilization operations in the main process building and APSF. Existing support utilities, such as the power house in $400 \mathrm{D}$-Area and maintenance facilities in the F-Area will also be utilized.

Training Facilities. The SRS Training Center is located in H-Area. The facility is located outside the 200-H Limited Area and is considered a Property Protection Area.

\subsection{Design Safety}

Special design considerations are required to ensure that:

- Radioactive materials are properly confined during processing operations

- Ventilation air from process operations is properly confined and filtered prior to release

- Operating personnel are adequately protected from radiation and airborne contamination 
- Process streams are properly treated and handled for release or disposal.

The total confinement system consists of one or more individual confinement barriers and systems that restrict releases of radioactive or hazardous materials to the environment or into areas normally occupied by plant personnel. Engineered safety features will be designed and used to prevent radioactive material and hazardous chemical releases. Design and construction of the PIP will incorporate the following safety considerations in accordance with DOE orders and applicable NRC regulations.

\subsubsection{Confinement Systems and Barriers}

Two types of confinement barriers will be used in the facility. "Total barriers" are those fabricated of material that prevent penetration of confined material without regard to the physical or chemical nature of the material. "Selective barriers" are mass transfer devices or filters to remove selected chemicals or particulate matter from a process or ventilation stream while allowing the bulk of the stream to pass. Barriers will be designed to withstand loadings due to conditions imposed by systems such as the process off gas, building ventilation systems, as well as loading caused by natural phenomena. Confinement systems will generally be constructed of nonflammable materials except where special functional requirements exist. Construction materials will be resistant to the corrosive effect of process and decontamination fluids at the design basis temperatures and pressures encountered.

\subsubsection{Ventilation and Off Gas}

The building ventilation and process off gas systems control the spread of airborne contamination through openings in barriers. By regulating the path of air or gas flow between these zones, gas leakage will be directed from zones of low potential to zones of higher potential for contamination.

\subsubsection{Natural Phenomena (Earthquakes, Wind, and Flood)}

Classification of plant facilities will be based on an item-by-item analysis. Each structure, system, or component (SSC) will be evaluated in terms of its importance in protecting the safety of employees and the public and in avoiding an unacceptable loss in accordance with DOE Order 420.1, DOE-STD-1020-94, and DOE-STD-1021-93.

The following natural phenomena are considered applicable to PIP and are treated as design basis events:

2.2.3.1 Earthquakes. The Design Basis Earthquake (DBE) for the PIP will be chosen in accordance with DOE-STD-1020-94. All safety class SSCs will be designed to withstand the DBE. Earthquakes exceeding the magnitude of the DBE are extremely unlikely events as defined in DOE-STD-3009-94. 
2.2.3.2 Tornadoes. The Design Basis Tornado (DBT) for the PIP will be chosen in accordance with DOE-STD-1020-94. All processing and storage building structures housing plutonium and/or high-level waste, the Zone 1 exhaust systems, and critical site effluent monitoring systems will be designed to withstand the DBT and DBT-generated tornado missiles. Tornadoes exceeding the magnitude of the DBT are extremely unlikely events as defined in DOE-STD-3009-94.

2.2.3.3 Floods. Flooding is of particular concern at plutonium processing facilities such as the PIP because of the potential for nuclear criticality accidents. The PIP will be designed to preclude flooding of areas in the PIP that contain plutonium. The Design Basis Flood (DBF) for the PIP will be chosen in accordance with DOE-STD1020-94. All processing and storage building structures housing plutonium and/or high-level waste, critical site effluent monitoring systems, and product canister storage vault racks will be designed to withstand the DBF. Floods exceeding the magnitude of the DBF are extremely unlikely events as defined in DOE-STD-3009-94.

\subsubsection{Systems Related to Safety}

Section 1300-3.2 of DOE Order 6430.1A, Guidance on Limiting Exposure of the Public, specifies that safety class items are those SSCs with any of the following characteristics:

- Those whose failure would produce exposure consequences that would exceed the guidelines in DOE Order 6430.1A, Section 1300-1.4, Guidance on Limiting Exposure of the Public, at the site boundary or nearest point of public access

- Those required to maintain operating parameters within the safety limits during normal operations and anticipated operational occurrences

- Those required for criticality safety

- Those required to monitor the release of radioactive materials to the environment during and after a Design Basis Accident (DBA)

- Those required to achieve and maintain the facility in a safe shutdown condition

- Those that control the safety class items described above.

The PIP will require the following:

- Safety class instrumentation and controls (I\&C), monitoring systems, and associated equipment

- Redundant electrical power distribution system with standby diesel generator 
- Safety class electrical equipment, limited to uninterruptible power supplies (UPS) for monitoring releases to the environment, criticality monitoring, and material control and accountability equipment.

The PIP will have heating, ventilation, and air conditioning (HVAC) systems and high efficiency particulate air (HEPA) filtering with provisions for redundant trains and equipment as required to facilitate maintenance activities such as HEPA filter cleaning while maintaining zone regulated air flow. HVAC systems for regulated zones will have emergency power supplied from a standby diesel generator source.

To ensure power for the detection and mitigation of plutonium in the off gas exhaust and cooling/collection systems, off gas monitoring systems will have emergency power supplied from a standby diesel generator source.

Effluent, radiation, and criticality monitoring will be required for process and waste areas or cells and associated subsystems for criticality and contamination concerns.

Emergency (backup), uninterruptible electrical power, and safety instrumentation will be required for safety class equipment to ensure redundant features are maintained.

\subsubsection{Fire Protection}

The design and construction of the PIP will require careful selection of materials and systems in order to meet the design criteria of DOE Order 420.1, Facility Safety; DOE Order 6430.1A, General Design Criteria; DOE Order 5480.4, Environmental, Safety and Health Protection Standards; DOE Order 5480.7A, Fire Protection; and National Fire Protection Association (NFPA) code requirements.

\subsubsection{Safety Class Instrumentation and Control}

Safety instrumentation is designed to detect malfunctions and reliably indicate failure. In those cases, appropriate control actions will be implemented.

The PIP processes will require most systems to be supported by safety class I\&C, electrical, and monitoring systems and equipment. The PIP will require area radiation and continuous air monitors to detect the spread of airborne and surface contaminants. Closed cooling water systems, if required, will be designed to supply cooling water. These cooling systems will be provided with radiation monitoring systems to detect contaminants in the cooling water supply.

Criticality monitoring will be required for the plutonium processing and storage cells or areas where the plutonium enters the melter feed stream. The off gas cooling and collection systems and the redundant HVAC systems will also require safety class criticality monitoring. The need for any additional criticality monitoring 
will be evaluated. Material control and accountability equipment and instrumentation will be required for accurate plutonium inventory from receipt through storage of the final product.

Standby (backup) electrical power provided by diesel generators will supply safety systems (e.g., HVAC) where redundant systems or equipment are necessary. Uninterruptible power supply systems will provide power for safety class instrumentation systems.

\subsubsection{Nuclear Criticality}

Processing and storage of plutonium involves the risk of nuclear criticality. Such operations at the DOE facilities require compliance with DOE Orders 420.1 and 6430.1A.

Subcritical limits are derived and documented in nuclear criticality safety evaluation (NCSE) reports. In addition to the numerous NCSEs that are produced for each step of the process, fault tree analyses, accident studies, and double contingency analyses are also generated. Double contingency analyses are explorations of credible scenarios that ensure the process designs incorporate sufficient safety factors so that two unlikely, independent, and concurrent process changes must occur before a criticality accident is possible.

In-depth computations of the effective neutron multiplication factor $\left(\mathrm{k}_{\text {eff }}\right)$ generate the subcritical limits of the system being evaluated. This calculation is almost exclusively performed with criticality computer codes. DOE orders, NRC guidance, and ANSI standards require that these criticality codes be validated. Typically, this validation involves the determination of applicable experiments, research into the experiments, development of computer models, calculations using those models, comparison of code and experimental results to develop bias, and the documentation of results.

Basic control methods for the prevention of nuclear criticality include:

- Provision of safe geometry design (preferred)

- Engineered density and/or mass limitation

- Provision of fixed neutron absorbers

- Use of administrative controls.

Nuclear incident monitors (NIMs) are used to detect unplanned criticality events at the DOE sites. NIMs are gamma detectors calibrated to respond to a $2.6 \times 10^{-4} \mathrm{C} / \mathrm{kg} / \mathrm{h}(1 \mathrm{R} / \mathrm{h})$ gamma dose rate. New, third generation NIMs are now available that will give improved maintainability and compliance with the most 
recent DOE orders, NRC guidance, and ANSI standards, particularly as regards requirements for seismic stability and redundant systems to reduce false alarms.

\subsubsection{Ventilation and Confinement}

Confinement barriers and systems will be selected in accordance with proven practices as described below.

- To limit the airborne spread of radioactive materials, the facility will be separated by confinement barriers into zones of various levels of contamination.

- The building ventilation and process off gas systems will control the spread of airborne contamination through openings in barriers. By regulating the path of air or gas flow between these zones, gas leakage will be directed from zones of low potential to zones of higher potential for contamination.

- The capacity of the ventilation system (in relation to confinement system requirements) to ensure that the velocity of gas flowing through any barrier opening will be sufficient to prevent the backflow of airborne contaminants through such openings: Air flow patterns must not be disrupted by winds, movement of equipment or personnel, or temporary opening of passageways through confinement barriers.

- Cooling water that could become contaminated by leakage of process solutions through defects in heat exchanger components will be contained in closed secondary circuits with independent primary heat transfer circuits. These circuits will be monitored for radioactivity.

- Penetrations through confinement barriers that could provide potential pathways for release of radioactivity to the environment will have means for isolating the penetration such as airlocks at entrances to zones. Penetrations for wiring, piping, and instrumentation will be sealed to prevent backflow of radioactivity to normally occupied areas.

- To monitor the integrity of total confinement barriers for gases, differential pressure monitors will be provided to indicate pressure differentials between confinement zones. To monitor total confinement barrier liquids, leakage will be detected by liquid high level alarms in specially designated leakage collection sumps. Leakage can also be measured by analytical devices that sound an alarm for contamination intrusion into normally uncontaminated tanks or process streams. Continuous air monitors will be used to indicate loss of function of a barrier, which could release radioactivity from a designated confinement area into an occupied area. 
- Standby power will be provided to those confinement barriers and systems where loss of confinement could result from loss of primary electrical service.

- Standby fans will be provided to function for essential fans that may become inoperative.

- The confinement barriers will be designed to maintain functional integrity under the hypothesized DBAs, where required.

\subsection{Safeguards and Security}

Protection of nuclear material involves both material control and accountability (MC\&A) and physical security activities. Accountable nuclear materials include SNMs, source materials, and other nuclear material identified in DOE Order 5633.3B, Control and Accountability of Nuclear Materials. The Safeguards and Security Program is divided into the following sections:

- Material control and accountability

- Assessments and evaluations

- Computer and information security

- Personnel security

- Protection program planning and management.

Integrated safeguards and security systems will effectively deter, prevent, detect, and respond to theft and diversion of nuclear material. In support of the U.S. nonproliferation policy, the DOE will make plutonium that is surplus to the nation's defense requirements available for verification and inspection by the International Atomic Energy Agency (IAEA), provided that no classified information is revealed.

The plutonium raw feed and immobilized plutonium product will be classified as SNM; and according to DOE Order 5633.3B, provisions for safeguards and security and for material control and accountability will be implemented to protect, control, and account for the materials at all times. Per Figure I-2 of DOE Order 5633.3B, the SNM category dictates the level of security necessary to ensure appropriate protection of the material. From Figure I-2 data, the raw plutonium feed and oxide will qualify as Nuclear Material Safeguards Category I or II with a "B" or "C" Attractiveness Level depending on material form and quantity. The highly radioactive canisters may also qualify as Category IV, Attractiveness Level E.

Although the PIP may have several categories of SNM on-site at any given time, the most conservative classification for design and overall facility safeguards and 
security will be Category I, Attractiveness Level B, while specific areas of the facility could be designed to other category/attractiveness levels. The facility requirements for the protection of safeguards and security interests originate from appropriate SNM Category I criteria outlined in DOE Order 5632.1C, Protection and Control of Safeguards and Security Interests, DOE Manual 5632.1C-1, Manual for Protection and Control of Safeguards and Security Interests, and other applicable DOE orders. For the PIP, general safeguards and security requirements are described below.

\subsubsection{Requirements for the Physical Protection of Category I Special Nuclear Material and Other Vital Equipment}

Category I SNM will be used or processed within material access areas (MAA) requiring a material surveillance program to detect unauthorized material flows and transfers. Locations within an MAA that contain unattended Category I SNM in use or process will be equipped with intrusion detection systems or other effective means of detection. An MAA will be contained within a protected area and will have defined physical barriers constructed to provide sufficient delay time to control, impede, or deter unauthorized access. MAA barriers will direct the flow of personnel and vehicles through designated portals and will include entry and exit inspections to provide reasonable assurance against the unauthorized introduction of prohibited items or the removal of SNM. Strategies and planning for the physical protection of SNM and vital equipment will be developed and will incorporate applicable DOE order requirements for the protection of safeguards and security interests. Site safeguards and security plans will define applicable threats and measures to protect vital equipment from hostile actions and vulnerability assessments (VAs) performed as required by DOE Order 5630.13A, Master Safeguards and Security Agreements.

2.3.1.1 Storage. Special nuclear material will be stored within an MAA. Special nuclear material characterized as Category I, Attractiveness Level B will be stored in a vault or provided enhanced protection that exceeds vault-type room storage (e.g., protective force response and/or activated barriers). For Category I, Attractiveness Level C, SNM will be stored in a vault or vault-type room. Vaults and vault-type rooms will conform with the vault construction requirements described in DOE Order 6430.1A, General Design Criteria.

2.3.1.2 Third-Party Inspection (IAEA). Space will be provided for third-party inspection (i.e., IAEA). The area includes the following features:

- A separate area for processing records, studying reports, calibrating and repairing instruments, and loading and unloading cameras, etc.

- A camera located at the vault entry point for recording the entry and removal of containers from the vault and identifying the containers by bar code 
number. The proximity of the material entering the vault will trigger the camera.

- Power to the equipment. This will be separated from the main facility, isolated from surges, and should be uninterruptible.

Power (including a UPS) and other utilities will be provided, but equipment will be provided by the inspection agency.

2.3.1.3 In-Transit. Protection requirements for quantities of special nuclear material in transit include the following:

- Domestic off-site shipments of Category I SNM are governed by the transportation safeguards system under the auspices of the Albuquerque Operations Office.

- Packages or containers containing SNM will be sealed with tamper-indicating devices.

- Protection measures for movement of material between protected areas onsite and between protected areas and staging areas will be under direct surveillance by the security officers to protect against threats established by site policy.

2.3.1.4 Intrusion Detection and Lighting. Intrusion detection systems will be installed to provide reasonable assurance that breaches of security boundaries are detected and that intrusion information is provided to security personnel. Intrusion detection systems will also be provided for vaults and vault-type rooms. Twentyfour hour protective lighting will be provided to permit detection and assessment of adversaries and to reveal unauthorized persons.

2.3.1.5 Access Control and Entry/Exit Inspections. Access is restricted to personnel with a need to enter the protected area and MAA. At routine exits from an MAA, metal detectors, SNM monitors, explosive detectors, and x-ray machines will be used to conduct inspections for prohibited articles and government property. Data and equipment access controls are applied on a graded basis. In addition to DOE Order 5633.3B, access controls may be governed by the DOE requirements for the control of classified documents and for computer security.

2.3.1.6 Barriers and Locks. Physical barriers such as fences, walls, doors, or activated barriers will be used to delay unauthorized access to security areas. Physical barriers will serve as the physical demarcation of the security area. When used for protection purposes, fencing will meet the construction requirements of DOE Order 6430.1A. Locks used in the protection of classified matter and Categories I and II SNM (e.g., security containers, safes, and vaults) will meet Federal Specification 
FF-L-2740, Locks, Combination, or Military Specification MIL-P-43607, Padlock, Key Operated, High Security, Shrouded Shackle.

2.3.1.7 Vaults and Vault-Type Rooms. Most Category I materials are stored in vaults or vault-type rooms. These rooms are equipped with approved intrusion alarm systems, and two authorized Q-cleared employees will be present to access Category I storage locations. Security devices assure the presence of two people. Most facilities use two combination locks. Each lock has a unique combination and access list. Nobody assigned to the vault has the combination to both locks. Facility personnel maintain lists of employees who may access storage areas, and security forces receive a copy of these lists. Security inspectors stationed in a central alarm station verify the presence of two authorized persons before granting access. Facility personnel update the access lists quarterly, and facility-specific procedures contain directions for accessing vaults and vault-type rooms. The minimum standards required for construction of SNM storage vaults other than modular vaults are detailed in DOE Order 6430.1A and apply to new construction, reconstruction, alterations, modifications, and repairs.

2.3.1.8 Communications. Communications equipment will be provided to aid in reliable information exchange between security personnel. The equipment must have two different technologies of voice communications to link the facility with each fixed post, central alarm station, secondary alarm station, and protected personnel dispatch point. Backup or alternative communications capabilities will be readily available upon failure of the primary communications system.

2.3.1.9 Acceptance and Validation Testing. Acceptance and validation tests are performed to confirm the ability of an implemented and operating system or element to meet an established protection requirement. Two levels of tests will be addressed in an overall safeguards and security acceptance and validation test program.

2.3.1.10 Maintenance. Security-related subsystems and components will be maintained in operable condition per DOE Order 4330.4B, Maintenance Management Program.

2.3.1.11 Posting Notices. Selection of facilities, installations, and real property for posting of signs will be based upon need for protection against espionage, sabotage, or depredation of safeguards and security interests.

2.3.1.12 Security Badges. Security badges shall indicate individuals' access limitations and/or approvals for the purpose of controlling entrance and exit to security areas and facilities and for safeguards and security-related identification purposes. 
UCRL-ID-128271 


\subsection{Site Map and Land Use Requirements}

\subsection{Site Map}

The site map of the SRS showing the PIP location is provided in Figure 3-1. The plutonium immobilization processing will be located in a new process building in F-Area. The DWPF vitrification plant in S-Area will be used to pour HLW glass into the plutonium-containing canisters. Existing waste management, analytical, and other support facilities will also be utilized to support the immobilization operations. The F-Area site plan is provided in Figure 3-2. The E-Area, C-Area, and $\mathrm{N}$-Area site plans showing the various waste management facilities in support of the PIP operations are provided in Figures 3-3 and 3-4. Detailed descriptions of the site plan and major buildings have been given in Sections 2.1.2 and 2.1.3.

\subsection{Land Area Requirements During Operation}

The PIP processing building will require $5,425 \mathrm{~m}^{2}$ (58,400 sq. $\mathrm{ft}$.) of new construction. Approximately $1,022 \mathrm{~m}^{2}(11,000 \mathrm{sq}$. $\mathrm{ft}$.) of area in the APSF will be used for receiving and storing incoming SNM feed. Two ha (4.9 acres) of new parking lots and $670 \mathrm{~m}(2,200 \mathrm{ft})$ of service road will also be required.

\subsection{Land Area Requirements During Construction}

Construction area requirements are shown in Table 3-1. Approximately 9.7 ha (24 acres) of land for new construction laydown will be required. The construction laydown area is shown in Figure 3-2, F-Area plot plan. New land area uses for construction will include 1.0 ha ( 2.5 acres) and 2.0 ha ( 4.9 acres) for new parking lots. No new roads or rail lines are required. The total land area disturbed during construction is approximately 17 ha (42 acres). 


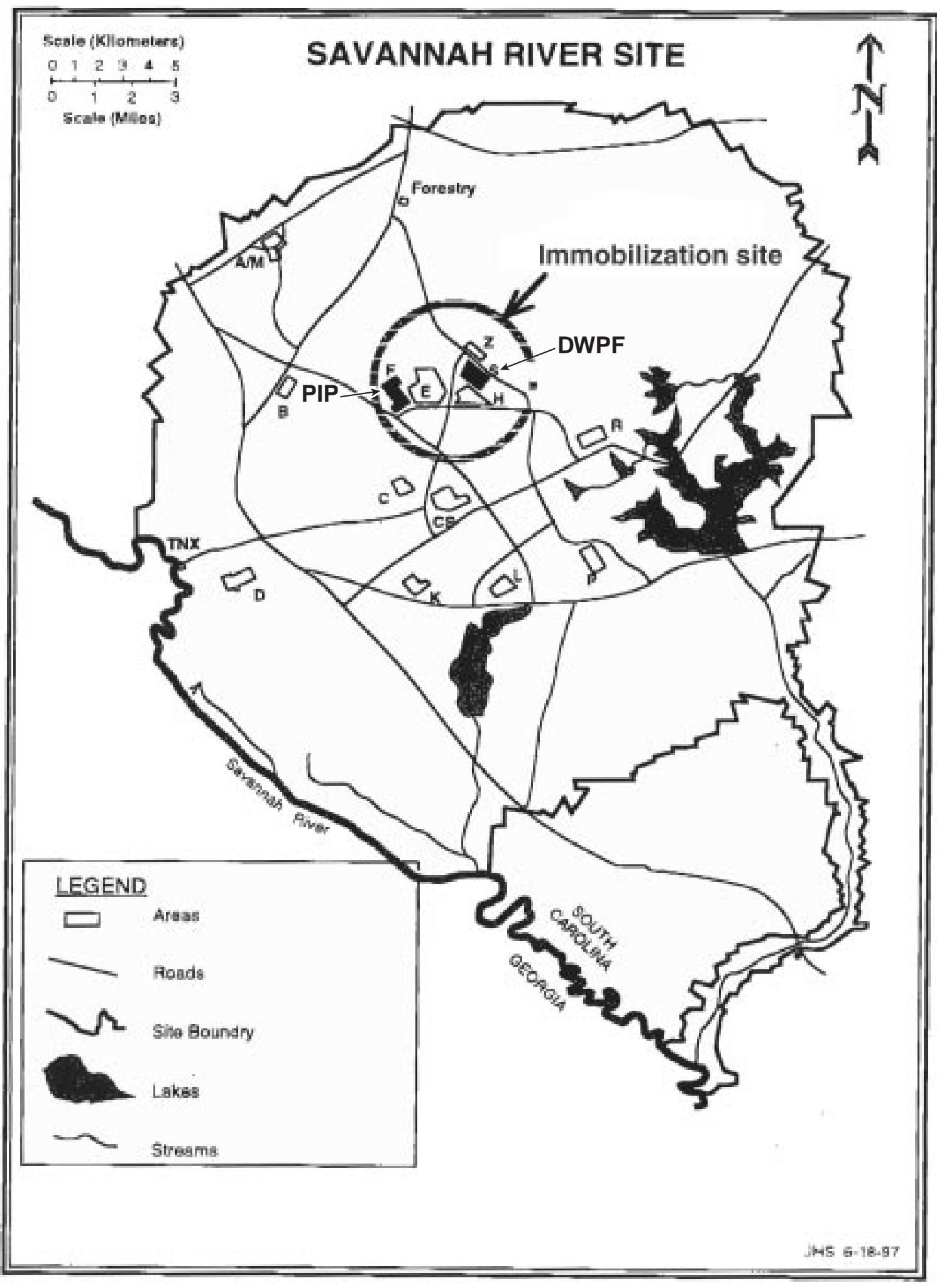

Figure 3-1. Savannah River Site site map. 
1. Main substation

2. Analytical laboratories (772-F)

3. Administration buildings (703-F and 707-F)

4. 221-F canyon building (including PSF, NSR)

5. Support facilities

6. Sand filters

7. Cooling towers

8. Fan house

9. Stack

10. Fire and medical station (709-F)

11. Security and entry control facility (701-F)

12. Laundry

13. Mock-up shop

14. Rail access

15. Waste tank farm

16. Other process building

17. APSF

18. PIP

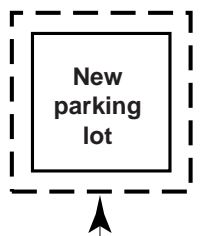

Disturbed land boundary

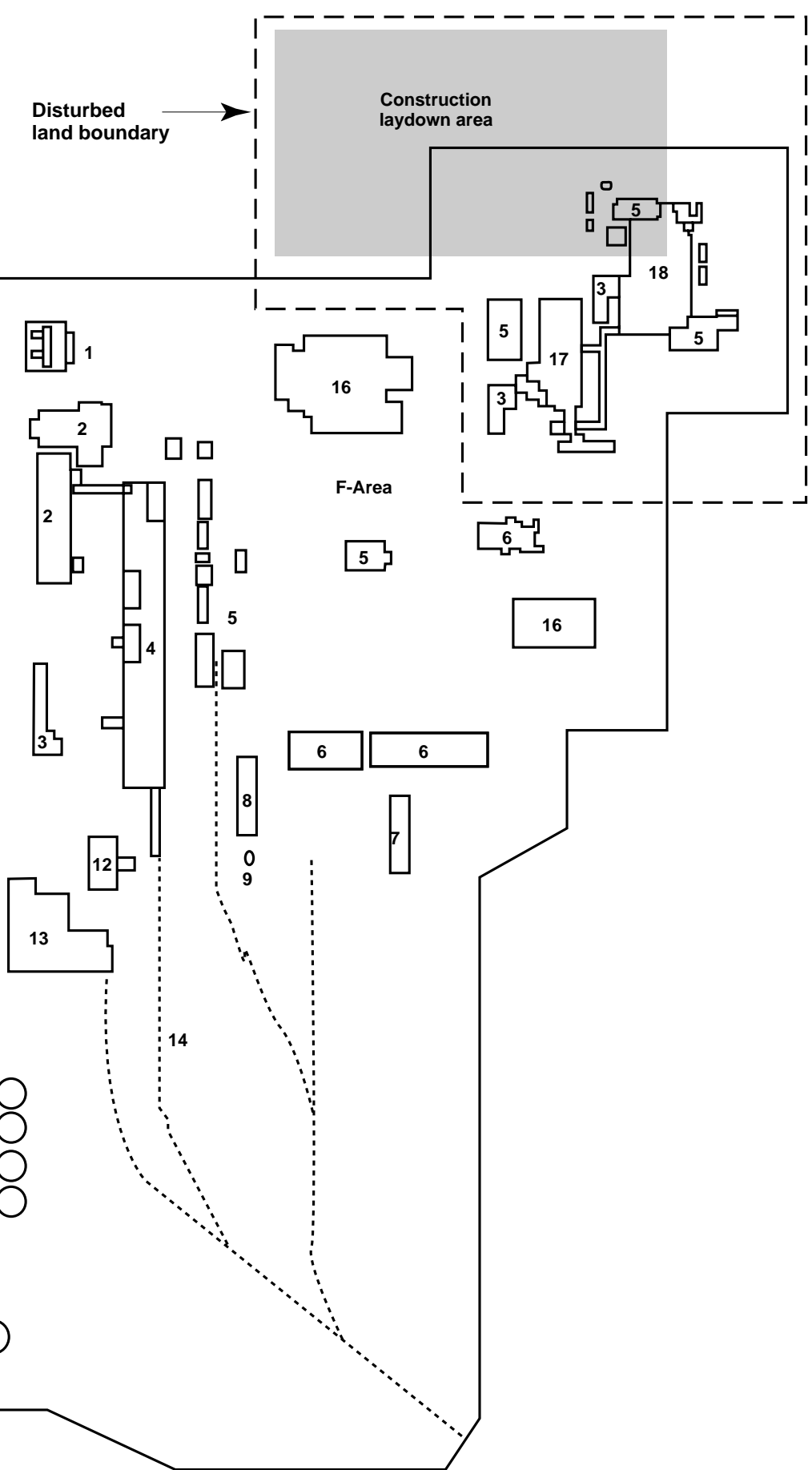

Figure 3-2. F-Area plot plan. 


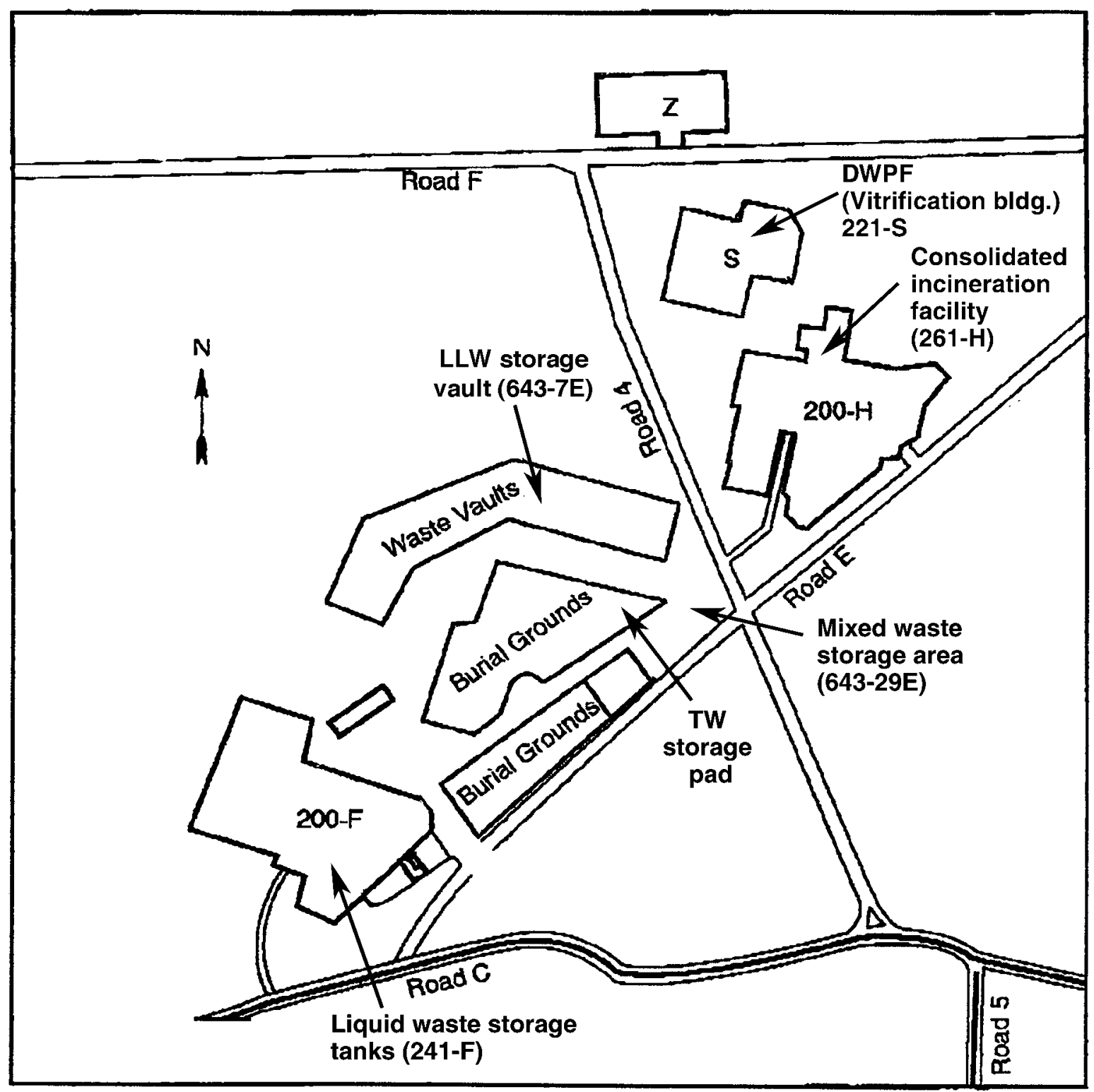

Figure 3-3. E-Area and surrounding areas site plan. 


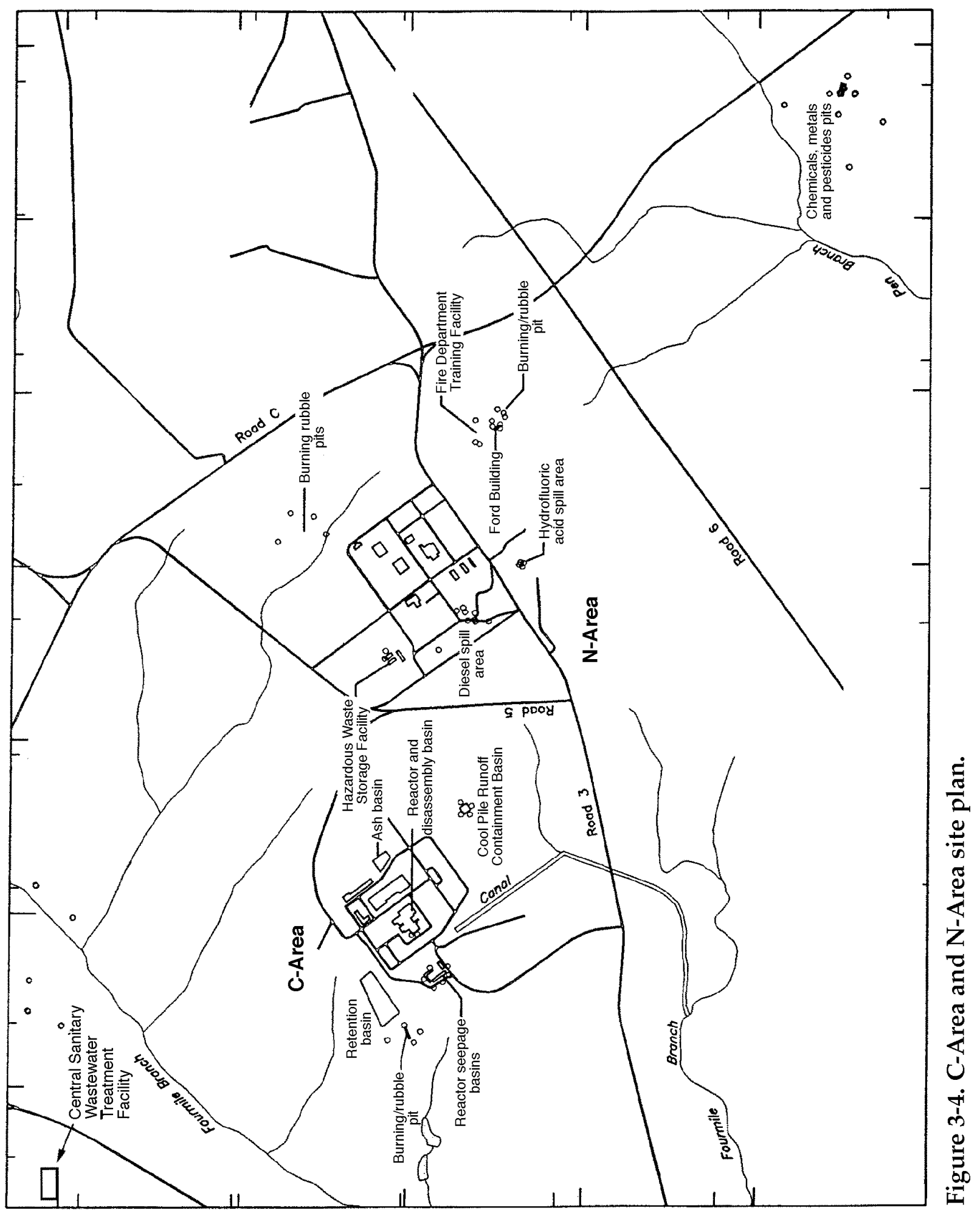


Table 3-1. Construction area requirements.

\begin{tabular}{|l|c|c|}
\hline \multicolumn{1}{|c|}{ Function } & Total area & New area \\
\hline $\begin{array}{l}\text { Construction laydown area, ha (acre) } \\
\text { (including spoils, topsoil stockpiles, etc.) }\end{array}$ & $9.7(24.0)$ & $3.4(8.4)$ \\
\hline Warehousing area, ha (acre) & $2.6(6.4)$ & 0 \\
\hline Waste storage area, ha (acre) & $0.10(0.25)$ & 0 \\
\hline Security area, ha (acre) & $1(2.46)$ & $1(2.46)$ \\
\hline New parking lots, ha (acre) & $2.0(4.9)$ & $2.0(4.9)$ \\
\hline New roads/rail lines, km (mile) & 0 & 0 \\
\hline
\end{tabular}

Notes:

- $50 \%$ of laydown area is in F-Area, $50 \%$ is in sitewide laydown area (central shops).

- $40 \%$ of existing laydown area is at F-Area, $60 \%$ in central shops. 


\subsection{Process Description}

The end-to-end glass immobilization process has been shown in the top-level flow diagram (Figure 2-1). The feed materials will come as oxide from the MD Pit Recovery Program and materials from the EM stabilization program and other programs.

Many of the non-pit plutonium feeds require physical processing and/or conversion to the oxide form. This conversion is performed in the plutonium conversion portion of the plant in gloveboxes. The processing required for each major feed type is:

- Metals and alloys - Metals and alloys will be converted to oxide by the HYDOX process. The oxide is packaged and stored for feed to the glass fabrication process.

- Metal reactor fuel - The metal fuel is in the form of plates clad in stainless steel. Cladding will be removed in a decladding operation. The metal will then be converted to the oxide using the HYDOX process. The oxide will be packaged and stored as feed for the glass fabrication process.

- Oxide reactor fuel - The oxide fuel consists of a fuel bundle or loose fuel pins. Hardware and cladding will be removed in the decladding operation. The oxide will then be size-reduced. The oxide will be packaged and stored as feed for the glass fabrication process.

- Oxides - The oxides will be calcined, halide-washed and calcined, or stored as feed for the glass fabrication process.

The oxide product from plutonium conversion will then be transferred to the first-stage immobilization process. This portion of the plant begins with blending and feed preparation operations. After oxide blending and milling, glass frit is added. The oxide is then fed to a glass melter to form plutonium glass. The glass will be poured into metal cans.

In the second-stage of the immobilization process, several metal cans will be placed in a rack assembly inside a HLW canister. The canisters will then be transferred to the DWPF where HLW glass will be added to encapsulate the cans, creating a radiation barrier.

\subsection{Plutonium Feed Conversion}

The plutonium immobilization process requires the plutonium in an oxide powder form. The plutonium conversion process (Figure 4-1) converts the 


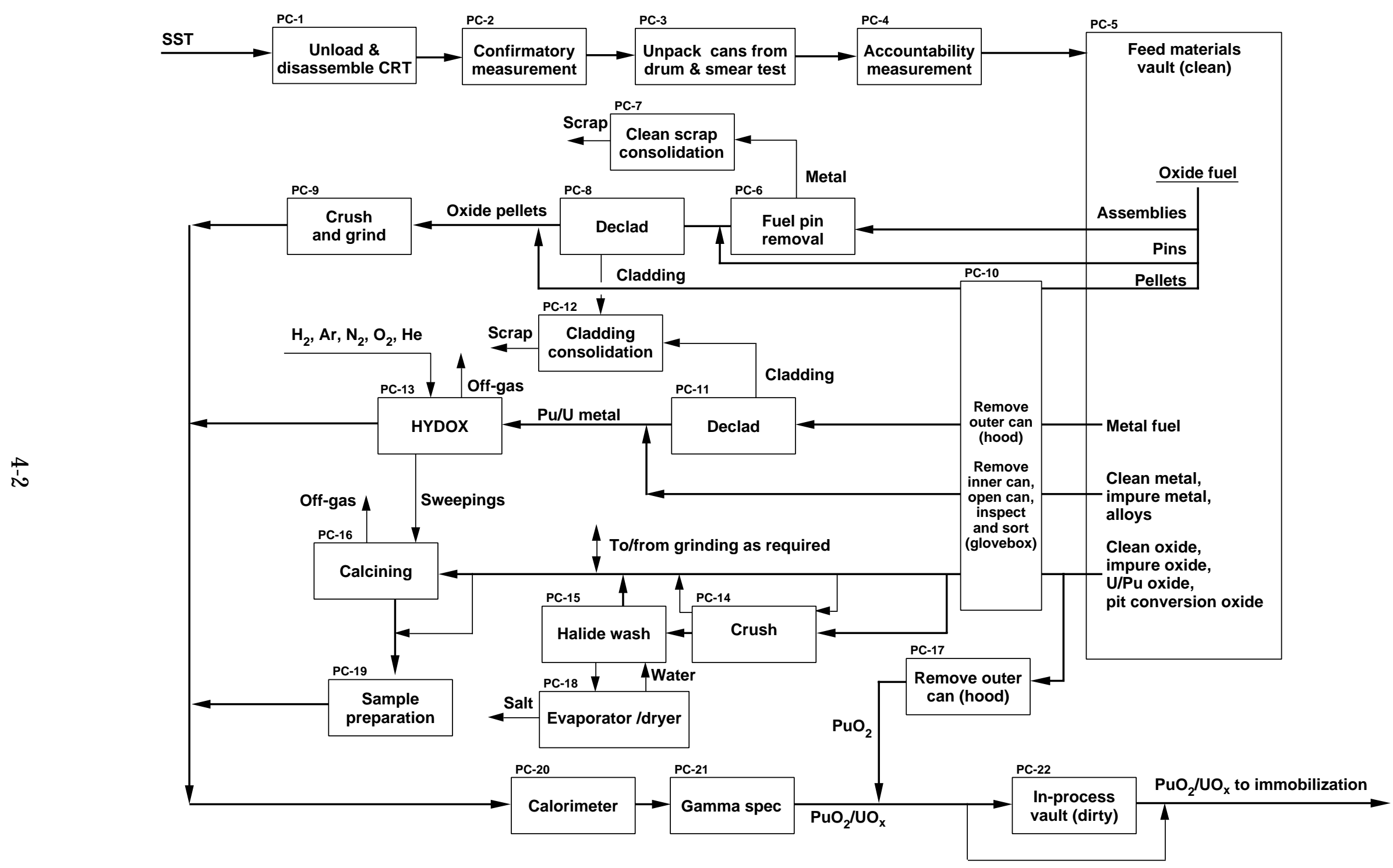

Figure 4-1. Plutonium conversion block flow diagram. 
incoming feed materials into an oxide powder form of the requisite physical characteristics and purity to meet immobilization requirements. The plutonium conversion process will perform the following functions:

- Receive shipments of material from DOE sites

- Perform material accountability measurements

- Unpack shipping containers

- Store incoming feed materials for up to six months

- Remove material from storage containers

- Convert metals to oxides

- Declad fuels

- Convert fuel pellets to powders

- Calcine oxides

- Remove halide impurities (if required).

Following the conversion process, some materials will be sampled and analyzed by $x$-ray fluorescence (XRF) spectrometry. The material will then be placed in storage cans and assayed for plutonium content using calorimetry and gamma-ray spectrometry. The interface between the plutonium conversion process and the first-stage immobilization process is an in-line storage vault containing up to two months of product from plutonium conversion.

\subsubsection{Material Receiving (PC-1, PC-2, PC-3 and PC-4)}

4.1.1.1 Function. In this area of the plant, plutonium contained in shipping containers will be off-loaded from SSTs (PC-1). The shipping containers will then be unpacked, and the nuclear material assayed using non-destructive techniques. Two assay techniques will be required. Neutron counters will be used to perform a preliminary confirmation (PC-2) that the material sent from the shipping site was the same material that was received. Material will then be staged through calorimetry and gamma-ray spectrometry to provide a more accurate material accountability (PC-4). Packaging material will be removed (PC-3) to the extent required for out-of-glovebox storage (two uncontaminated barriers). This area will contain hoods to handle contaminated shipping containers and equipment to decontaminate these containers.

4.1.1.2 Feeds. The feed to this area of the plant is SST shipments of plutoniumbearing material in shipping containers. The plutonium will be in the form of oxide 
and metal fuel (fuel assemblies, pins, plates, or pellets), clean and impure metals, alloys, and oxides (clean or containing impurities including halides).

4.1.1.3 Products. The products from the material receiving area will be empty shipping containers and unprocessed plutonium immobilization feed material in storage containers.

4.1.1.4 Utilities Required. Utility services required to support this area include:

- 120/208 VAC power for fork lift charging, instruments, small motors, and facility lighting

- Instrument air

- Wash water for SSTs.

4.1.1.5 Chemicals Required. Solution for container decontamination will be required. The required volume will be less than $4 \mathrm{~L}$ ( 1 gal) per container.

4.1.1.6 Special Requirements. Shielding will be required for all operations to provide protection from both gamma and neutron radiation.

HEPA-filtered ventilation systems will be required for the unloading dock, container unpacking and assay areas, and contaminated package hoods.

This area shall also include equipment and systems for the physical protection of SNM, alpha air monitoring, and criticality monitoring and alarm systems.

4.1.1.7 Waste Generated. Contaminated waste will be generated if contaminated shipping containers are received and decontaminated. Uncontaminated wastes will consist of wash water, paper, gloves, failed equipment, and cleaning supplies.

\subsubsection{Feed Material Storage Vault (PC-5)}

4.1.2.1 Function. The feed material storage vault (PC-5) will be configured to store six months of incoming material to the immobilization plant in the asreceived material storage containers. The vault will be automated with systems to move storage containers to a material assay station and provide material safeguards.

4.1.2.2 Feeds. The feed to the feed material storage vault will be SNM contained in material storage containers.

4.1.2.3 Products. The product from the feed material storage vault will be SNM contained in material storage containers.

4.1.2.4 Utilities Required. Utility services required to support this area include:

- 120/208/480 VAC power for instruments, motors, and facility lighting

- Instrument air.

4.1.2.5 Chemicals Required. None. 
4.1.2.6 Special Requirements. Shielding will be required around personnel access areas to provide protection from both gamma and neutron radiation.

HEPA-filtered ventilation will be required for the vault.

This area shall also include equipment and systems for the physical protection of SNM, alpha air monitoring, and criticality monitoring and alarm systems.

4.1.2.7 Waste Generated. Uncontaminated wastes will consist of paper, failed equipment, and cleaning supplies.

\subsubsection{Unpacking and Sorting (PC-10 and PC-17)}

4.1.3.1 Function. In this process operation, material storage containers will be unpacked, and the plutonium material will be removed, inspected, and routed for processing. In order to minimize the generation of TRU waste, the material storage container will be placed into a hood and the outer container removed (PC-10 and PC-17). This container will be monitored for contamination and discarded as low level or industrial waste. The inner container will then be transferred to a glovebox and unpacked. Following unpacking, the material will be inspected to determine the appropriate process route. The material may be sampled and the sample sent to the analytical laboratory. The inner container and, if present, the material container will be either reused for material storage or decontaminated and discarded as low level or TRU waste. Material not requiring chemical conversion will be placed into an inline material storage container and transferred to the in-line storage vault. Large fuel assemblies will not be processed through this area.

4.1.3.2 Feeds. The feed will be SNM contained in material storage containers.

4.1.3.3 Products. The product will be SNM contained in either in-line material transfer containers or in-line material storage containers.

4.1.3.4 Utilities Required. Utility services required to support this area include:

- 120/208 VAC power for instruments, motors, and facility lighting

- Instrument air.

4.1.3.5 Chemicals Required. None.

4.1.3.6 Special Requirements. Shielding will be required around the glovebox to provide protection from both gamma and neutron radiation.

HEPA-filtered ventilation systems will be required for both the glovebox and process room.

This area shall include equipment and systems for the physical protection of SNM, alpha air monitoring, and criticality monitoring and alarm systems. 
4.1.3.7 Waste Generated. Material packaging containers will be discarded as low level or TRU waste. If decontamination is performed, some decontamination wastes will be generated. In general, TRU and low level glovebox wastes will be generated that include glovebox gloves, equipment, windows, and filters. In addition, uncontaminated wastes consisting of paper, gloves, failed equipment, and cleaning supplies will be generated.

\subsubsection{Fuel Decladding (PC-6, PC-7, PC-8, PC-9, PC-11, and PC-12)}

4.1.4.1 Function. These process operations remove cladding from ZPPR and FFTF fuel and consolidate the cladding material for disposal. The system for decladding the ZPPR fuel will be a shielded glovebox with equipment to breach the stainless-steel cladding and remove the metal plates (PC-11). The decladded metal plates will be sent to the HYDOX glovebox and the cladding material will be sent to the cladding consolidation glovebox. The cladding consolidation glovebox consists of a system to either melt or compact the cladding into a consolidated form for disposal (PC-12).

The system for FFTF fuel will consist of a station to receive and disassemble fuel assemblies (PC-6), an introduction airlock, and a decladding glovebox (PC-8). The decladding glovebox will contain equipment to breach the cladding and remove the fuel pellets. Pellets will be sorted according to fissile material content. Pellets containing plutonium or enriched uranium will be ground to an acceptable particle size (PC-9). Nonactinide pellets will be discarded. Cladding materials will be sent to the cladding consolidation glovebox (PC-7).

4.1.4.2 Feeds. The feeds will be fuel plates contained in in-line material transfer containers and fuel assemblies, rods, and pellets.

4.1.4.3 Products. The product will be either unclad metal plates or oxide pellets.

4.1.4.4 Utilities Required. Utility services required to support this area include:

- 120/208/480 VAC power for instruments, process equipment, motors, and facility lighting

- Instrument air

- Vacuum (roughing)

- Argon system for decladding glovebox

- Inert atmosphere gas supply and purification systems.

4.1.4.5 Chemicals Required. None.

4.1.4.6 Special Requirements. Shielding will be required around the gloveboxes to provide protection from both gamma and neutron radiation. 
HEPA-filtered ventilation systems will be required for both the gloveboxes and process room.

This area shall include equipment and systems for the physical protection of SNM, alpha air monitoring, and criticality monitoring and alarm systems.

4.1.4.7 Waste Generated. Cladding materials will be consolidated and then discarded as TRU waste. Oxide pellets containing SNM below accountability limits will be discarded as TRU waste. In general, TRU and low level glovebox wastes will be generated that include glovebox gloves, equipment, windows, and filters. In addition, uncontaminated wastes consisting of paper, gloves, failed equipment, and cleaning supplies will be generated.

\subsubsection{Metal to Oxide Conversion (PC-13)}

4.1.5.1 Function. This process operation consists of equipment to convert metal to oxide. The HYDOX process (PC-13) will be used for this purpose. Metal ingots or ZPPR plates will be transferred into the HYDOX glovebox and fed into the HYDOX furnace. In the furnace, the material will first be hydrided into a fine powder. The hydride powder will then be converted to oxide by nitriding followed by oxidation. The product oxide will be transferred from the furnace, sampled as required, and placed into in-line material storage containers. Support equipment includes vacuum systems, gas supply systems, gas purification systems, and a calcination furnace to treat all glovebox sweepings.

4.1.5.2 Feeds. The feeds will be metal plates and ingots contained in in-line material transfer containers.

4.1.5.3 Products. The product will be oxide powder contained in in-line material storage containers. Glovebox sweepings will be transferred to the calcination furnace.

4.1.5.4 Utilities Required. Utility services required to support this area include:

- 120/208 VAC power for instruments, process equipment, furnaces, motors, and facility lighting

- Instrument air

- Vacuum (roughing)

- Argon for glovebox and furnace purging and pneumatic systems inside the HYDOX glovebox

- Nitrogen process gas

- Hydrogen process gas 
- Helium process gas

- Oxygen process gas

- Air process gas.

4.1.5.5 Chemicals Required. For the HYDOX process hydrogen, nitrogen, helium, and oxygen gases are required.

4.1.5.6 Special Requirements. Shielding will be required around the gloveboxes to provide protection from both gamma and neutron radiation.

HEPA-filtered ventilation systems will be required for both the gloveboxes and process room.

An inert atmosphere will be required because of the pyrophoricity of the hydrides. This area shall also include equipment and systems for the physical protection of SNM, alpha air monitoring, and criticality monitoring and alarm systems.

4.1.5.7 Waste Generated. Process gases will be vented to a process off gas system and exhausted from the plant. In general, TRU and low level glovebox wastes will be generated that include glovebox gloves, equipment, windows, and filters. In addition, uncontaminated wastes consisting of paper, gloves, failed equipment, and cleaning supplies will be generated.

\subsubsection{Calcination (PC-16)}

4.1.6.1 Function. This process consists of a calcining system (PC-16) to remove moisture or other impurities from oxide materials and passivate glovebox sweepings. This system will be used to process oxide feed materials that have not previously been calcined and to calcine oxide from halide washing operations and sweepings from various gloveboxes. The system will be equipped with automated material handling systems.

4.1.6.2 Feeds. The feeds will be oxides, returned samples, and sweepings contained in in-line material transfer containers.

4.1.6.3 Products. The product will be oxide powder contained in in-line material storage containers.

4.1.6.4 Utilities Required. Utility services required to support this area include:

- 120/208 VAC power for instruments, process equipment, furnaces, motors, and facility lighting

- Instrument air

- Argon for glovebox and furnace purging and pneumatic systems inside the glovebox 
- Nitrogen process gas

- Air process gas.

4.1.6.5 Chemicals Required. Nitrogen and air are required for the calcination furnace.

4.1.6.6 Special Requirements. Shielding will be required around the glovebox to provide protection from both gamma and neutron radiation.

HEPA-filtered ventilation systems will be required for both the glovebox and process room.

This area shall include equipment and systems for the physical protection of SNM, alpha air monitoring, and criticality monitoring and alarm systems.

4.1.6.7 Waste Generated. Process gases will be vented to a process off gas system and exhausted from the plant. In general, TRU and low level glovebox wastes will be generated that include glovebox gloves, equipment, windows, and filters. In addition, uncontaminated wastes consisting of paper, gloves, failed equipment, and cleaning supplies will be generated.

\subsubsection{Halide Removal (PC-14, PC-15, and PC-18)}

4.1.7.1 Function. This process operation removes halides from oxides. Currently the Hanford site has oxide materials that may contain significant concentrations $(10-20 \%)$ of halide impurities. Removal of these halides may be required to meet the feed specification for the immobilization process. This system will size-reduce the feed oxide material (PC-14), place it into a leach vessel (PC-15), filter the solution, and dry the product oxide (PC-18). Filtrate solution will be evaporated to a dry residue, which will be packaged for disposal as TRU waste. Product oxide will be transferred to the calcination operation to complete water removal.

4.1.7.2 Feeds. The feeds will be halide-contaminated oxides contained in in-line material transfer containers.

4.1.7.3 Products. The product will be washed oxide filter cake contained in in-line material storage containers.

4.1.7.4 Utilities Required. Utility services required to support this area include:

- 120/208 VAC power for instruments, process equipment, furnace, motors, and facility lighting

- Instrument air

- Air process gas.

4.1.7.5 Chemicals Required. Water will be used as the washing medium. 
4.1.7.6 Special Requirements. Shielding will be required around the gloveboxes to provide protection from both gamma and neutron radiation.

HEPA-filtered ventilation systems will be required for both the gloveboxes and process room.

This area shall include equipment and systems for the physical protection of SNM, alpha air monitoring, and criticality monitoring and alarm systems.

4.1.7.7 Waste Generated. Evaporated salt wastes will be packaged and disposed of as TRU waste. In general, TRU and low level glovebox wastes consisting of glovebox gloves, equipment, windows, and filters will be generated. In addition, uncontaminated wastes consisting of paper, gloves, failed equipment, and cleaning supplies will be generated.

\subsubsection{Sample Preparation and Product Assay (PC-19, PC-20, and PC-21)}

4.1.8.1 Function. The sample preparation and product assay system consists of three unit operations. A glovebox sample preparation operation (PC-19) will provide samples to an analytical laboratory. Impurity analysis will be performed by an XRF spectrometer. Isotopics and plutonium content will be measured by a gamma-ray spectrometry (PC-21) and calorimeter (PC-20) system. The product assay systems will be in-line systems and will have automated material handling equipment.

4.1.8.2 Feeds. For the XRF system the feed will be oxide contained in transfer canisters. The feed to the gamma-ray spectrometer and calorimeter will be oxides contained in in-line material transfer containers.

4.1.8.3 Products. The product from the gamma-ray spectrometer and calorimeter will be oxides contained in in-line material transfer containers. The product from the XRF system will be sample pellets that will be fed back to the calcination furnace.

4.1.8.4 Utilities Required. Utility services required to support this area include:

- 120/208 VAC power for instruments, process equipment, furnace, motors, and facility lighting

- Instrument air

- Air process gas.

4.1.8.5 Chemicals Required. Starch may be used in preparing the XRF samples.

4.1.8.6 Special Requirements. Shielding will be required around the sample prep glovebox to provide protection from both gamma and neutron radiation. 
HEPA-filtered ventilation systems will be required for both the glovebox and process room.

This area shall include equipment and systems for the physical protection of SNM, alpha air monitoring, and criticality monitoring and alarm systems.

4.1.8.7 Waste Generated. In general, TRU and low level glovebox wastes consisting of glovebox gloves, equipment, windows, and filters will be generated. In addition, uncontaminated wastes consisting of paper, gloves, failed equipment, and cleaning supplies will be generated.

\subsubsection{In-Process Storage Vault (PC-22)}

4.1.9.1 Function. The in-process storage vault (PC-22) will provide a buffer to enable campaigning materials through the plutonium conversion operations. Materials will be stored in the vault while material analysis is in process and until blending formulations are determined for the immobilization operation. To minimize radiation exposure, the vault will be in-line and automated. Material will be stored in in-line material transfer containers.

4.1.9.2 Feeds. The feed to the vault will be oxides contained in in-line material transfer containers.

4.1.9.3 Products. The product from the vault will be oxides contained in in-line material transfer containers.

4.1.9.4 Utilities Required. Utility services required to support this area include:

- 120/208 VAC power for instruments, process equipment, motors, and facility lighting

- Instrument air.

4.1.9.5 Chemicals Required. None.

4.1.9.6 Special Requirements. Shielding will be required around the in-line vault to provide protection from both gamma and neutron radiation.

HEPA-filtered ventilation systems will be required for both the vault and process room.

This area shall include equipment and systems for the physical protection of SNM, alpha air monitoring, and criticality monitoring and alarm systems.

4.1.9.7 Waste Generated. In general, TRU and low level glovebox wastes will be generated that include glovebox gloves, equipment, windows, and filters. In addition, uncontaminated wastes consisting of paper, gloves, failed equipment, and cleaning supplies will be generated. 


\subsection{First-Stage Immobilization - Immobilization in Glass}

The first-stage immobilization process prepares the oxide from plutonium conversion and combines this oxide with glass frit to produce a dry powder feed to a cylindrical induction melter. The melter produces a lanthanide borosilicate glass containing approximately $8 \mathrm{wt} \%$ plutonium encased in a stainless steel can. A number of these cans, containing up to $1.3 \mathrm{~kg}(2.9 \mathrm{lb})$ of plutonium, are mounted in an open metal rack, which is then inserted in a sectioned cylindrical DWPF canister. The canister head is welded in place. The can-in-canister assembly is then ready to be transported to the DWPF.

Figure 4-2 shows the glass process block flow diagram. This process involves blending and grinding of plutonium oxide and frit followed by controlled feeding of the frit/oxide mixture to an induction-heated melter to produce a homogeneous plutonium glass. The melter off gas is cooled and HEPA filtered prior to discharge. The glass drains from the melter via gravity to a stainless steel can, which is cooled prior to removal from the glovebox through a bagless transfer system. The product cans are leak-tested, assayed, and sent to the product vault for storage.

\subsubsection{Melter Feed Preparation (IG-1, IG-2, IG-3, IG-4, and IG-5)}

4.2.1.1 Function. This operation provides for isotopic blending (IG-1), size reduction, and blending of the plutonium oxide with glass frit to produce feed for the melter.

Individual cans of plutonium oxide, containing a wide range of isotopes and impurities, are selected from the in-process storage vault (IG-2) for blending to produce a final batch with an average composition of about $8 \mathrm{wt} \%$ plutonium. The blended batch is packaged in smaller cans for material accountability measurement (IG-3), then the blended oxide is placed in a grinder (IG-4) for particle size reduction to achieve faster dissolution in the melter. The ground oxide is weighed and then blended (IG-5) with glass frit containing the neutron absorbers hafnium and gadolinium for feeding to the melters.

4.2.1.2 Feeds. Feed material is plutonium oxide or plutonium/uranium oxide mixtures produced from various plutonium feed materials in the plutonium conversion process.

4.2.1.3 Products. Product from the melter feed preparation will be a plutonium/uranium oxide-glass frit mixture that is approximately $8 \mathrm{wt} \%$ plutonium and $3 \mathrm{wt} \%$ uranium.

4.2.1.4 Utilities Required. Utility services required to support blending and grinding operations within gloveboxes include: 


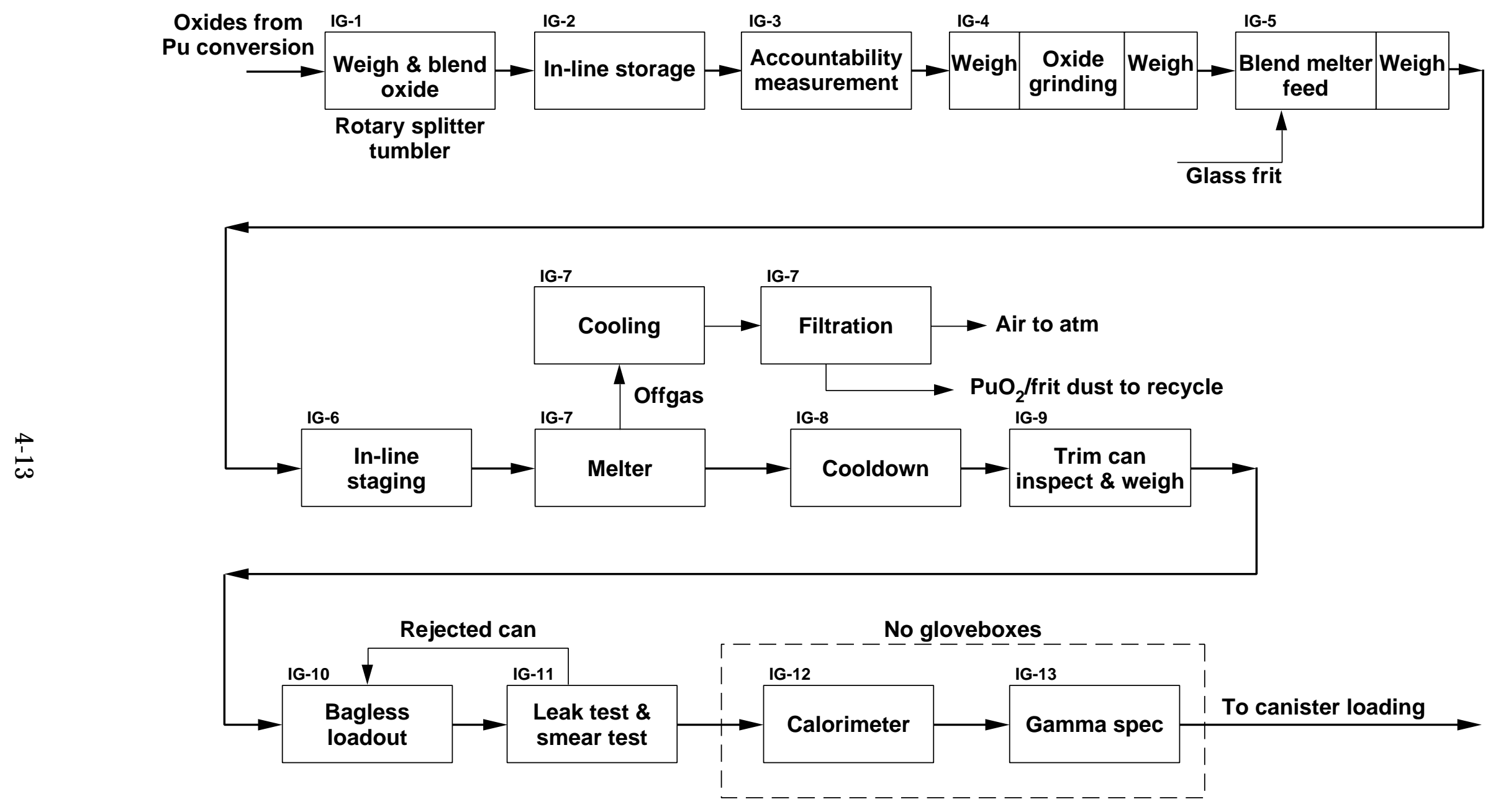

Figure 4-2. First-stage immobilization block flow diagram. 
- 120/208 VAC power for small motors and facility lighting

- Dry air supply for oxide handling gloveboxes

- Instrument air.

4.2.1.5 Chemicals Required. Glass frit including the neutron absorbers hafnium and gadolinium used in the melter process must be within specifications for particle size distribution and chemical composition as determined by the RD\&T program.

4.2.1.6 Special Requirements. Each process operation will be evaluated to determine glovebox shielding requirements from both gamma and neutron radiation.

Independent, filtered exhaust ventilation shall be provided for both process room and glovebox exhaust for confinement of plutonium oxide.

This process shall include equipment and systems for the physical protection of SNM and criticality monitoring and alarm systems.

4.2.1.7 Waste Generated. Process waste associated with feed preparation will consist of transfer cans containing feed materials. Non-process waste, consisting of contaminated filters, tools, failed gloves, and equipment, will also be generated in support of process operations, and will be processed for disposal as either TRU or LLW.

\subsubsection{Melter Operation/Plutonium Glass Production (IG-6 to IG-13)}

4.2.2.1 Function. The glass production process includes feeding and operation of the melter to produce glass, pouring glass into a can, removing the filled can from the glovebox, and doing a leak test and accountability assay of individual plutonium glass filled cans.

The plutonium oxide/glass frit mixture, taken from in-line storage (IG-6), is fed at a controlled rate to the melters (IG-7), which are electrically heated to about $1,500^{\circ} \mathrm{C}\left(2,700^{\circ} \mathrm{F}\right)$ to melt the frit and dissolve the plutonium oxide to form a homogeneous glass melt. The glass drains via gravity into a stainless steel can and is cooled (IG-8). The can is trimmed and inspected (IG-9), sealed in a bagless loadout can (IG-10), leak-tested (IG-11), removed from the glovebox for accountability measurement (IG-12 and 13), and sent to canister loading.

4.2.2.2 Feeds. Feed material for the melter operation is the ground, blended mixture of glass frit and plutonium/uranium oxide.

4.2.2.3 Products. Product from the melter operation will be stainless steel cans of nominally $4 \mathrm{~L}$ (1 gal) of glass containing dissolved plutonium/uranium oxide. These cans will be overpacked into an outer can that has a welded closure. The can will then be tested for leak-tightness. 
4.2.2.4 Utilities Required. Utility services required to support melter operation include the following:

- 480 VAC electric power for melters

- 120/208 VAC power for lighting, small motors, and welder control

- Cooling water for melter transformer, induction coils, and off gas cooling

- Dry air supply to melter feed system glovebox

- Instrument air

- Argon for purging of overpack can weld

- Helium for leak testing of overpack can.

4.2.2.5 Chemicals Required. No special chemicals are required for melter operation.

4.2.2.6 Special Requirements. Each process operation will be evaluated to determine glovebox shielding requirements from both gamma and neutron radiation.

Independent, filtered exhaust ventilation shall be provided for both process room and glovebox exhaust for confinement of plutonium oxide.

This process shall include equipment and systems for the physical protection of SNM and criticality monitoring and alarm systems. Accountability assay instrumentation is also required.

4.2.2.7 Waste Generated. Process waste associated with the melter operation will consist of transfer cans containing feed materials, oxide and frit entrained in the melter off gas, and can waste from the bagless transfer process. Non-process waste, consisting of contaminated filters, failed tools and equipment, gloves, and melter crucibles, will also be generated in support of process operations and will be processed for disposal as either TRU or LLW.

\subsection{Second-Stage Immobilization with High Level Waste Glass}

\subsubsection{Canister Loading (CL-1 to CL-16)}

The canister loading operations are shown in Figure 4-3. After receipt and staging (CL-1) and weighing (CL-2), the product cans are stored in the product vault (CL-3). The product cans containing plutonium-glass will be removed from the vault, placed into a canister rack (CL-4), and attached in place (CL-6) to prevent movement during shipment to DWPF. The rack (CL-5) will be cleaned and inspected prior to loading (CL-7) into the lower section of a pre-inspected (CL-8), two-part DWPF 


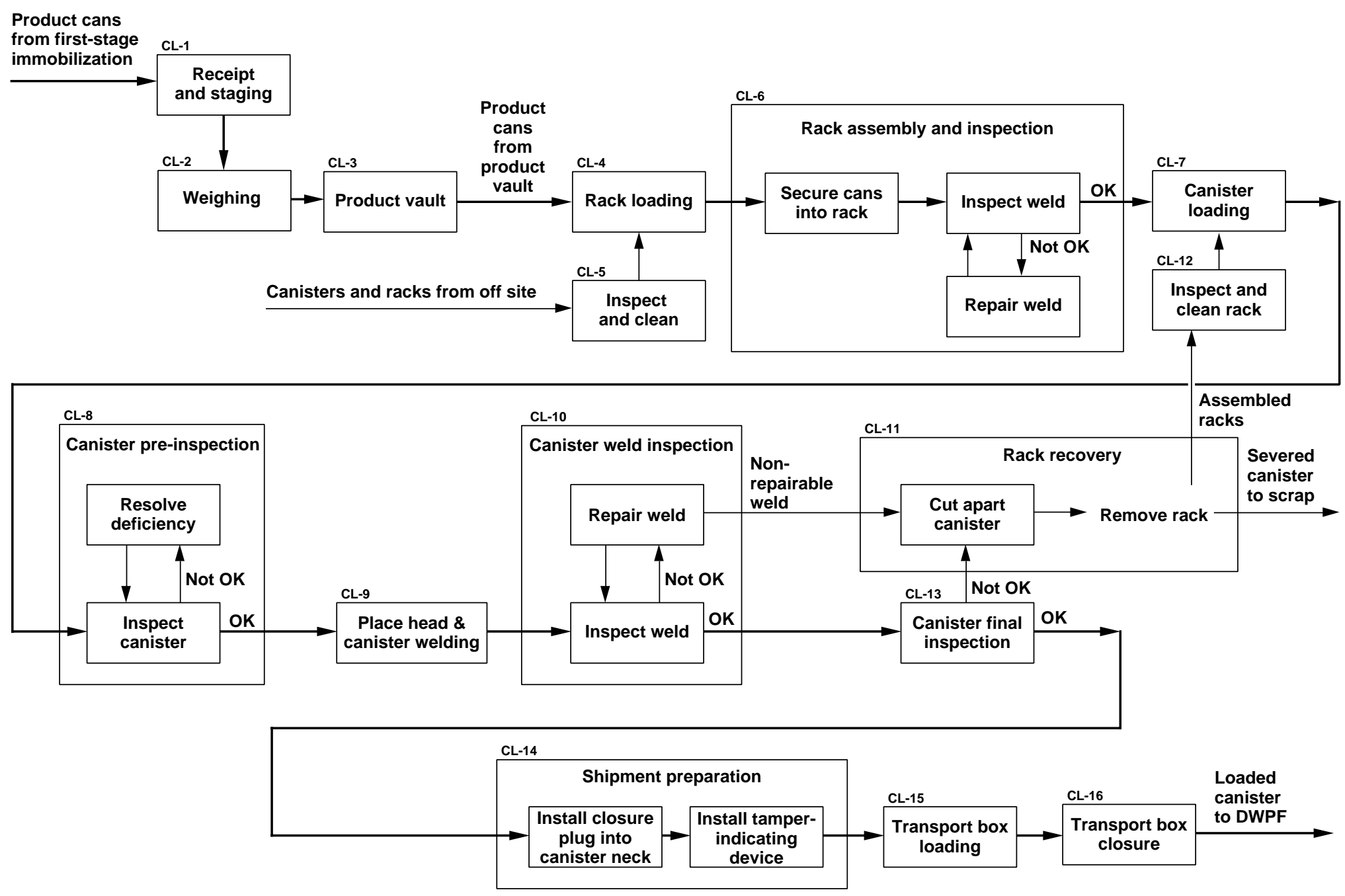

Figure 4-3. Second-stage immobilization canister loading block flow diagram. 
canister. The canister head will be then welded (CL-9) into place, and final inspections (CL-10, and CL-13) and leak testing will be performed. The completed canister (CL-14) will be loaded into a shielded transport box (CL-15) for shipment to DWPF (CL-16).

If a canister fails weld inspection, the product can rack will be recovered (CL-11), cleaned and inspected (CL-12), and recycled to canister loading.

4.3.1.1 Function. Canister loading mounts the plutonium-glass cans into the DWPF canister; completes canister assembly, inspection, and testing; and transports the canister to DWPF.

4.3.1.2 Feeds. Feed materials for canister loading are the individual cans of plutonium-glass, a two-part DWPF canister that has been prepared for circumferential welding, and the canister rack for can loading.

4.3.1.3 Products. The product from the canister loading will be DWPF canisters, each containing 20 cans of plutonium-glass. Twenty cans of plutonium-glass is acceptable can-loading for the canister, based on preliminary modeling of the HLW glass pour and the plutonium-glass can size. The selection of the final design loading will consider radionuclide availability as well as form quality, facility size, safety factors, and repository waste acceptance criteria. For this data call, a plutonium loading of $8 \mathrm{wt} \%$ within the plutonium-glass can and 20 cans per canister have been assumed.

4.3.1.4 Utilities Required. Utility services required to support the canister loading include the following:

- 480 VAC power supply for welder, and overhead gantry, and canister shuttle

- 120/208 VAC power supply for instrumentation and closed circuit TV (CCTV)

- Compressed air for pneumatic tool operation

- Argon for canister weld purge

- Nitrogen for canister pressure testing

- Helium for canister leak testing.

4.3.1.5 Chemicals Required. Radiographic film developer chemicals are required for canister loading.

4.3.1.6 Special Requirements. This process shall include equipment and systems for the physical protection of SNM, and criticality monitoring and alarm systems. Accountability assay instrumentation is also required.

Can loading, canister assembly, and canister movement and transportation will require remote operation due to high radiation exposure rates. This will include 
automated systems for can and canister movement, weld examination, and canister leak and pressure testing.

Transport of canisters from the loading area to DWPF will be made via a canister transporter. The canisters will be remotely loaded into a transfer cask or similar confinement box, which will be unloaded in the canister inspection area.

4.3.1.7 Waste Generated. Typical process waste from canister loading operations includes swipes from cleaning operations, and atmospheric releases of nitrogen and helium from pressure and leak testing activities. Other waste from welding operations includes residue from dye-penetrant testing and chemical residues from development of radiographic film used in weld examination. Non-process waste includes failed tools and equipment generated in support of operations. All waste generated should be free of radioactive contamination since the feed cans received from the melter operation are in an externally clean overpack can.

\subsubsection{Canister Filling (CF-1, CF-2, CF-3, and CF-4)}

Figure 4-4 illustrates the operations of canister filling in the second-stage immobilization process. After transportation (CF-1), receipt and unloading of canisters (CF-2), and tamper-indicating device (TID) confirmation (CF-3) at the DWPF, HLW glass is poured (CF-4) into the canister around the steel cans containing the plutonium-glass. Following canister filling with HLW glass, the canister assembly will be decontaminated, plug-welded, smear-tested and transported to the GWSB for interim storage until final shipment to a federal repository. This program will result in the production of approximately 1,900 total canisters of plutonium-glass encapsulated in HLW glass.

4.3.2.1 Function. DWPF canisters containing cans of plutonium-glass are filled with HLW glass. The finished canisters are stored in the GWSB.

4.3.2.2 Feeds. Feed materials for the DWPF canister filling are the DWPF canisters containing the cans of plutonium-glass and the HLW glass for filling the canister.

4.3.2.3 Products. The product from the canister filling process will be DWPF canisters, each containing 20 cans of plutonium-glass surrounded by HLW glass.

The can-in-canister assembly will have a minimum radiation dose of $0.026 \mathrm{C} / \mathrm{kg} / \mathrm{h}(100 \mathrm{R} / \mathrm{h})$ at $1 \mathrm{~m}(3 \mathrm{ft})$ from the package surface and will retain this exposure level for at least 30 years after fabrication.

4.3.2.4 Utilities Required. Utility services required to support the canister filling include the following:

- 480 VAC power supply for welder, overhead gantry, and canister shuttle

- 120/208 VAC power supply for instrumentation and CCTV 

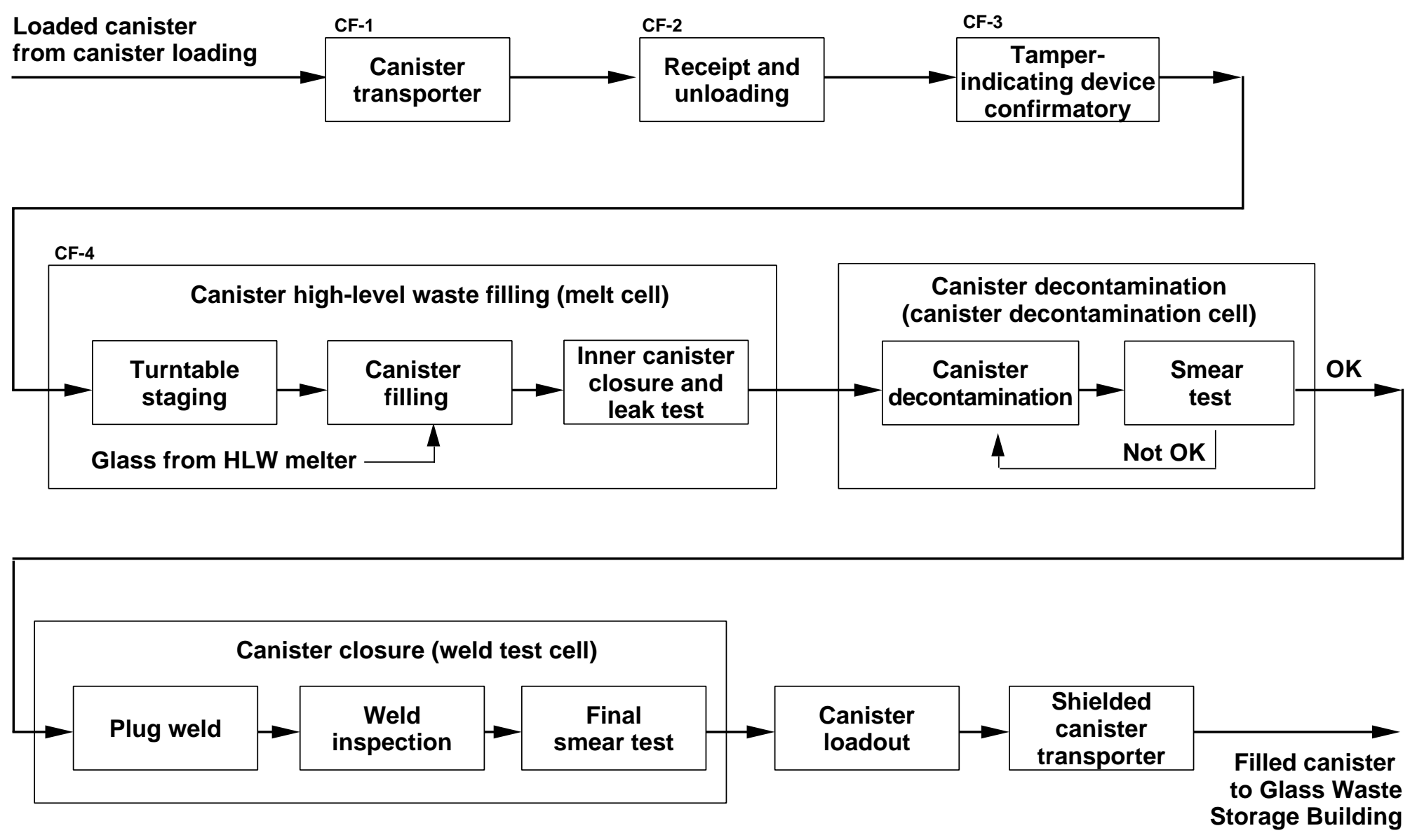

Figure 4-4. Second-stage immobilization canister filling block flow diagram. 
UCRL-ID-128271

- Compressed air for pneumatic tool operation.

4.3.2.5 Chemicals Required. No special chemicals are required for canister filling.

4.3.2.6 Special Requirements. This process shall include equipment and systems for the physical protection of SNM.

The canisters will be moved individually through the inspection area to the transfer tunnel to the melt cell. Radiation shielding must be provided during movement through these areas.

4.3.2.7 Waste Generated. No incremental waste is generated because DWPF is pouring the same amount of HLW glass. 


\subsection{Resource Needs}

This section describes the estimated resources required due to installation of the PIP located in new buildings and using DWPF. Included are resource needs during construction and operation of the facility.

\subsection{Materials/Resources Consumed During Construction}

Table 5-1 provides an estimate of major construction materials and utilities consumed during construction.

Table 5-1. Resource needs for construction.

\begin{tabular}{|l|c|}
\hline Resource requirement & Annual average consumption \\
\hline Utilities & \\
\hline Electricity, MWh & 4,000 \\
Peak demand, MW & 1.5 \\
\hline Diesel fuel, L (gal) & $320,000(84,544)$ \\
Coal, tonne (ton) & $148(164)$ \\
\hline Groundwater, $\mathrm{L}$ (gal) & $4.0 \times 10^{7}\left(1.06 \times 10^{7}\right)$ \\
Peak demand, L (gal) & $15,000(3,963)$ \\
Surface water & 0 \\
Peak demand, $\mathrm{L}$ (gal) & 0 \\
\hline Building materials & $17,500(22,890)$ \\
\hline Concrete, $\mathrm{m}^{3}\left(\mathrm{yd} \mathrm{d}^{3}\right)$ & $5,700(6,289)$ \\
\hline Steel, tonne $($ ton $)$ & $6,000(19,686)$ \\
\hline Electrical raceway, $\mathrm{m}\left(\mathrm{ft}^{2}\right)$ & $20,000(65,620)$ \\
\hline Electrical wire $\& \mathrm{cable}^{\mathrm{m}}(\mathrm{ft})$ & $15,000(49,215)$ \\
\hline Piping, $\mathrm{m}(\mathrm{ft})$ & $870(9,325)$ \\
\hline Steel decking, $\mathrm{m}^{2}\left(\mathrm{ft}^{2}\right)$ & $335(3,586)$ \\
\hline Steel siding, $\mathrm{m}^{2}\left(\mathrm{ft}^{2}\right)$ & $2,165(23,313)$ \\
\hline Built-up roof, $\mathrm{m}^{2}\left(\mathrm{ft}^{2}\right)$ & $465(5,021)$ \\
\hline Interior partitions, $\mathrm{m}^{2}\left(\mathrm{ft}^{2}\right)$ & $695(900)$ \\
\hline Lumber, $\mathrm{m}^{3}\left(\mathrm{yd}^{3}\right)$ & $55(58.6)$ \\
\hline HVAC ductwork, tonne (ton) & $6,600(71,002)$ \\
\hline Asphalt paving, $\mathrm{m}^{2}\left(\mathrm{ft}^{2}\right)$ & \\
\hline
\end{tabular}

Notes:

- Coal usage is one year's consumption annualized for three years of construction.

- Peak demand is the maximum rate expected during any hour. 


\subsection{Materials/Resources Consumed During Operation}

\subsubsection{Utilities Consumed}

Annual utility consumption for facility operation is presented in Table 5-2, including electricity, fuel, and water usage.

Table 5-2. Resource needs during operation.

\begin{tabular}{|l|c|}
\hline \multicolumn{1}{|c|}{ Resource requirement } & Annual average consumption \\
\hline Utilities & \\
\hline Electricity, MWh & 13,000 \\
Peak demand, MW & 2.7 \\
\hline Coal, tonne (ton) & $445(491)$ \\
Natural gas, m ${ }^{3}$ (scf) & $0(0)$ \\
Oil, L (gal) & $0(0)$ \\
Diesel fuel, L (gal) & $25,000(6605)$ \\
Gasoline, on-site transportation, L (gal) & $4,100(1083)$ \\
\hline Groundwater, L (gal) & $49,250,000(13,012,000)$ \\
Peak demand & $45,000(11,904)$ \\
Surface water, L (gal) & $0(0)$ \\
Peak demand & $0(0)$ \\
\hline Process chemicals & \\
\hline Gases, m ${ }^{3}$ (scf) & $290(10,241)$ \\
Hydrogen & $260(9,182)$ \\
Oxygen & $110(3,885)$ \\
Nitrogen & $390(13,773)$ \\
Argon & $2,500(88,288)$ \\
Helium & $110(29.06)$ \\
\hline Liquids, L (gal) & \\
Process Water & $55,000(121,275)$ \\
\hline Solids, kg (lb) & $150,000(330,750)$ \\
Frit & $1,100(2,400)$ \\
S/S canister, canister rack, product cans & \\
Absorbents & \\
\hline
\end{tabular}


Table 5-2. (cont.)

\begin{tabular}{|c|c|}
\hline Non-process chemicals & \\
\hline Gases, $\mathrm{m}^{3}$ (scf) & $190,000(6,709,850)$ \\
Argon (includes canister welding, & $2,100(74,151)$ \\
bagless loadout) & $350(12,359)$ \\
Nitrogen & \\
Helium & $400(106)$ \\
\hline Liquids, L (gal) & $200(53)$ \\
Hydraulic fluid & $1,150(304)$ \\
Cutting oil & \\
Lubricating oil & $12.0(26.46)$ \\
Solids, kg (lb) & $4.0(8.82)$ \\
Film development chemicals & $6.0(13.23)$ \\
Ammonium thiosulfate & $2.0(4.41)$ \\
Sodium sulfate & $2.0(4.41)$ \\
Potassium sulfate & $2.0(4.41)$ \\
Hydroquinone & $57.3(126)$ \\
Glutaraldehyde & $84.1(185)$ \\
Potassium acetate & $100(222)$ \\
Sodium hypochlorite & \\
Polyphosphate & $5.0(5.5)$ \\
Corrosion inhibitor & $1.7(1.9)$ \\
Rradioactive materials used in process & $0(0)$ \\
\hline Plutonium, tonne (ton) - feed material & \\
Uranium, tonne (ton) - feed material & \\
uranium for UO ${ }_{2}$ plant & \\
\hline
\end{tabular}

Notes:

- $\quad$ Peak demand is the maximum rate expected during any hour.

- $\quad$ For gases, standard cubic feet should be measured at $101 \mathrm{kPa}(14.7 \mathrm{psia})$ and $15^{\circ} \mathrm{C}\left(60^{\circ} \mathrm{F}\right)$.

- Coal consumption is for steam heating.

- Diesel fuel consumption is based on weekly one-hour testing of diesel generators for standby power.

- Gasoline consumption assumes four vehicles driven $32 \mathrm{~km}$ (20 miles) per day at $7.7 \mathrm{~km} / \mathrm{L}(18 \mathrm{mpg})$.

- Groundwater consumption is based on a DOE standard for drinking and sanitary usage, as well as cooling tower make-up water.

- Absorbent weight assumes a minimum 10:1 ratio of solid-to-liquid weight to dispose of spills and decontamination liquids as solid waste.

- Film development chemicals assume radiography of 190 canister welds per year, using a total of 38 L (10 gal) of "fixer" (ammonium thiosulfate/sodium sulfate) and 38 L (10 gal) of "developer" (potassium sulfate/hydroquinone/potassium acetate/glutaraldehyde). 


\subsubsection{Water Balance}

Figure 5-1 is a preliminary conceptual water balance diagram for the PIP in new buildings at SRS.

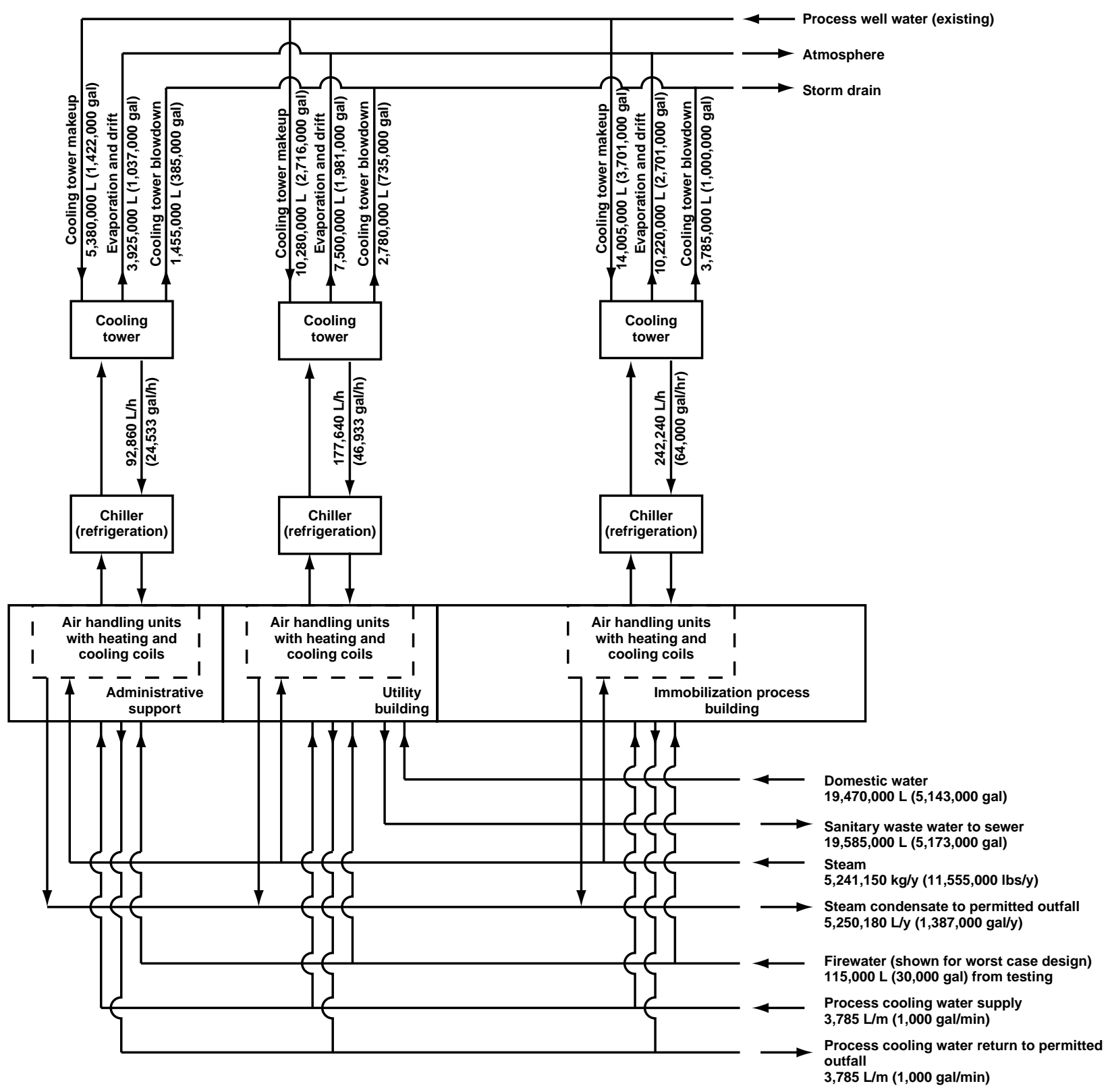

Figure 5-1. Annual water balance for plutonium immobilization in glass using new facilities at SRS. 


\subsubsection{Chemicals Consumed}

Table 5-2 shows chemicals and materials consumed annually during normal operations. In addition to chemicals required for process and support systems, stainless steel canister, canister rack, and product can materials are also included.

\subsubsection{Radiological Materials Required}

The radiological material requirements for the PIP are the process feeds. 
UCRL-ID-128271 


\subsection{Employment Needs}

This section provides preliminary estimates of the employment needs of the facility during both operation and construction. Note that employment shown is for all on-site facilities.

\subsection{Employment Needs During Construction}

Table 6-1 provides an estimate of the employment by year during construction.

Table 6-1. Employment during construction.

\begin{tabular}{|l|l|c|c|c|}
\hline $\begin{array}{c}\text { Construction } \\
\text { year }\end{array}$ & $\begin{array}{c}\text { Labor category } \\
\text { (if available) }\end{array}$ & $\begin{array}{c}\text { Number } \\
\text { of shifts }\end{array}$ & $\begin{array}{c}\text { Number of } \\
\text { employes per } \\
\text { shift }\end{array}$ & $\begin{array}{c}\text { Number of } \\
\text { construction } \\
\text { days per year }\end{array}$ \\
\hline Calendar year 1 & Craft workers & 1 & 260 & 240 \\
& Administrative & 1 & 12 & 240 \\
& Management & 1 & 40 & 240 \\
& Total & & 312 & 240 \\
\hline Calendar year 2 & Craft workers & 1 & 375 & 240 \\
& Administrative & 1 & 18 & 240 \\
& Management & 1 & 55 & 240 \\
& Total & & 448 & 240 \\
\hline Calendar year 3 & Craft workers & 1 & 230 & 240 \\
& Administrative & 1 & 12 & \\
& Management & 1 & 40 & 282 \\
& Total & & \multicolumn{2}{|c|}{} \\
\hline
\end{tabular}

\subsection{Employment Needs During Operation}

Table 6-2 provides labor category descriptions and the estimated numbers of employees required to operate the facility. Personnel required to operate the DWPF are not included. 
Table 6-2. Annual employment requirements during operation.

\begin{tabular}{|c|c|c|c|c|}
\hline Labor category & $\begin{array}{c}\text { Number of } \\
\text { shifts }\end{array}$ & $\begin{array}{l}\text { Number of } \\
\text { employees } \\
\text { per shift }\end{array}$ & $\begin{array}{c}\text { Total number of } \\
\text { employees }\end{array}$ & $\begin{array}{c}\text { Number of } \\
\text { operating days } \\
\text { per year }\end{array}$ \\
\hline $\begin{array}{l}\text { Officials and } \\
\text { managers }\end{array}$ & 1 & 5 & 5 & 240 \\
\hline $\begin{array}{l}\text { Professionals } \\
\text { Tech support }\end{array}$ & 1 & 11 & 11 & 240 \\
\hline $\begin{array}{l}\text { Technicians } \\
\text { Operations } \\
\text { RCO } \\
\text { Lab support } \\
\text { Shift supv }\end{array}$ & $\begin{array}{l}5 \\
5 \\
5 \\
5\end{array}$ & $\begin{array}{c}22 \\
8 \\
4 \\
5\end{array}$ & $\begin{array}{c}110 \\
40 \\
20 \\
25\end{array}$ & $\begin{array}{l}365 \\
365 \\
365 \\
365\end{array}$ \\
\hline $\begin{array}{l}\text { Office and clerical } \\
\text { Ops support } \\
\text { Clerical }\end{array}$ & $\begin{array}{l}1 \\
1\end{array}$ & $\begin{array}{c}10 \\
4\end{array}$ & $\begin{array}{c}10 \\
4\end{array}$ & $\begin{array}{l}240 \\
240\end{array}$ \\
\hline $\begin{array}{l}\text { Craft workers } \\
\text { (skilled) } \\
\text { Maintenance }\end{array}$ & 5 & 6 & 30 & 365 \\
\hline $\begin{array}{l}\text { Service workers } \\
\text { Security }\end{array}$ & 4 & 4 & 16 & 365 \\
\hline Total & & & 271 & \\
\hline
\end{tabular}

Notes:

- New positions to support immobilization.

- Five-shift operation is 24-hour, seven-day rotation, with an extra shift dedicated to training.

- Security force is based on additional manpower required to provide physical protection for the new mission in an underground facility.

- Operations staffing takes credit for personnel performing activities in APSF (receiving, confirmatory measurement, unpackaging, and accountability).

- Security for intrasite shipment of canisters and unloading of canisters to the DWPF melt cell will be provided by existing site mobile protective force personnel.

\subsection{Badged Employees at Risk of Radiological Exposure}

Operating employees at the facility will be subjected to low radiation doses. The estimated average annual dose to all badged workers and estimated maximum annual dose to all badged workers during construction and operations at the facility are shown in Tables 6-3 and 6-4. 
Table 6-3. Radiation doses to on-site workers during construction.

\begin{tabular}{|l|c|}
\hline $\begin{array}{l}\text { Average annual effective dose equivalent to all workers at the facility, } \\
\mu \mathrm{Sv} / \mathrm{y} \text { (mrem/y) }\end{array}$ & 40 (4) \\
\hline $\begin{array}{l}\text { Maximum annual effective dose equivalent to a worker at the facility, } \\
\mu \mathrm{Sv} / \mathrm{y} \text { (mrem/y) }\end{array}$ & 60 (6) \\
\hline Total number of badged workers & 0 \\
\hline
\end{tabular}

Note: New construction will not produce any personnel exposure above background.

Table 6-4. Radiation doses to on-site workers during operations.

\begin{tabular}{|l|c|}
\hline $\begin{array}{l}\text { Average annual effective dose equivalent to all badged workers at the } \\
\text { facility, } \mu \mathrm{Sv} \text { (mrem) }\end{array}$ & $\begin{array}{c}7,500 \\
(750)\end{array}$ \\
\hline $\begin{array}{l}\text { Maximum effective dose equivalent to a badged worker at the facility, } \\
\mu \mathrm{Sv} \text { (mrem) }\end{array}$ & $\begin{array}{c}20,000 \\
(2,000)\end{array}$ \\
\hline Total number of badged workers & 257 \\
\hline
\end{tabular}

Note: The average dose is an initial estimate based on qualitative judgments and a design limit of $20 \mathrm{mSv}$ (2 rem) maximum effective dose equivalent to an individual. The associated equipment layouts, operating and maintenance procedures, and design features such as automated equipment and shielding will be developed as part of the detailed plant design.

The dose estimates for operations have been deliberately chosen to be conservative. The maximum dose is $20 \mathrm{mSv}(2,000 \mathrm{mrem})$ for an individual dose. The DOE exposure design limit per 10CFR835 of $10 \mathrm{mSv} / \mathrm{y}(1,000 \mathrm{mrem} / \mathrm{y})$ is estimated on the average of all badged workers. The DOE target of $5 \mathrm{mSv} / \mathrm{y}$ ( $500 \mathrm{mrem} / \mathrm{y}$ ) is recognized. However, using the $5 \mathrm{mSv} / \mathrm{y}$ ( $500 \mathrm{mrem} / \mathrm{y}$ ) estimate as an environmental impact is premature. There is not sufficient detail available in the following areas:

- Realistic estimate of source material radiation levels based on blending/ feed lots.

- Adequate definition of specific work functions and unit operations that would allow time motion evaluation of dose received by operators.

- Better than preconceptual understanding of the cost and construction difficulties to provide shielding.

- Work function definition and conceptual layout information, particularly for existing facilities, to determine opportunities for a cost-benefit of automation.

- How international inspection may affect all of the above. 
- Reasonable estimate of the exposure to maintenance personnel who are required to maintain the operational and control equipment in place for a fully automated process.

Although the process material dose rate in the glass vitrification process after the glass frit blending step is approximately eight times higher than in the ceramic immobilization process, based on preliminary dose calculations, the predominant worker dose exposure is from the plutonium conversion operations in the front end of the immobilization process. There is little difference in overall dose exposure to all badged workers at the immobilization facility for both the glass and ceramic processes. The higher dose rate in glass vitrification is primarily due to the increase in neutron source term from $(\alpha, n)$ reactions with boron- 11 contained in glass frit. This assumes that plutonium process operations downstream of the glass frit blending will be automated and the process area will have additional shielding for glass immobilization. Additional measures, such as removing source term materials and adding portable shielding, will also be employed during maintenance activities to minimize worker exposure. 


\subsection{Wastes and Emissions from the Facility}

\subsection{Wastes and Emissions During Construction}

This section describes the wastes, effluents, emissions, and radioactive releases caused by construction activities of the proposed facility. The data are shown in Tables 7-1 to 7-3.

\subsubsection{Solid and Liquid Wastes}

7.1.1.1 Transuranic Wastes. No TRU waste is expected to be generated from construction.

7.1.1.2 Low Level Wastes. No LLW is expected to be generated during construction.

7.1.1.3 Mixed Low Level Wastes. No mixed LLW is expected to be generated during construction.

7.1.1.4 Hazardous Wastes. Construction work may generate hazardous wastes such as lubricants, solvents, paints, and coolants, as shown in Table 7-1. These hazardous wastes will be treated and disposed of, in accordance with EPA's Resource Conservation and Recovery Act (RCRA) guidelines, at an SRS facility or shipped to an off-site facility.

7.1.1.5 Nonhazardous Wastes. The nonhazardous waste generated during the construction of the proposed facility will include liquids and solids, as shown in Table 7-1. Liquid sanitary wastes will be sent to the existing sanitary sewer. Inert construction debris will be disposed of in sanitary landfills. Reusable construction materials will be stored for later on-site use. Paper, aluminum cans, and cardboard will be collected for recycling. Scrap metal, office equipment, drums, and other salvageable items will be sold to an off-site vendor.

\subsubsection{Emissions}

Gaseous emissions from construction activities include engine exhaust from construction equipment and vehicles, as shown in Table 7-2. Engine emissions are based on the estimated total amount of diesel fuel consumed by heavy construction equipment. The amount of fugitive dust produced will be proportional to the land area cleared and graded for new construction.

Radioactive releases resulting from the facility construction are not expected, as shown in Table 7-3. In areas where the land will be disturbed, the soil is not radiologically contaminated. 
UCRL-ID-128271

Table 7-1. Estimated waste generated during construction.

\begin{tabular}{|c|c|c|c|c|}
\hline $\begin{array}{l}\text { Waste } \\
\text { category }\end{array}$ & $\begin{array}{l}\text { Annual } \\
\text { volume }\end{array}$ & $\begin{array}{c}\text { Total } \\
\text { estimated } \\
\text { volume }\end{array}$ & $\begin{array}{c}\text { Waste } \\
\text { description }\end{array}$ & $\begin{array}{c}\text { Anticipated } \\
\text { treatment and/or } \\
\text { disposal method }\end{array}$ \\
\hline Transuranic & & & \multirow{3}{*}{ - } & \multirow{3}{*}{ - } \\
\hline Liquid, L (gal) & 0 & 0 & & \\
\hline Solid, $\mathrm{m}^{3}\left(\mathrm{ft}^{3}\right)$ & 0 & 0 & & \\
\hline Low level & & & \multirow{3}{*}{ - } & \multirow{3}{*}{ - } \\
\hline Liquid, L (gal) & 0 & 0 & & \\
\hline Solid, $\mathrm{m}^{3}\left(\mathrm{ft}^{3}\right)$ & 0 & 0 & & \\
\hline Mixed low level & & & \multirow{3}{*}{ - } & \multirow{3}{*}{ - } \\
\hline Liquid, L (gal) & 0 & 0 & & \\
\hline Solid, $\mathrm{m}^{3}\left(\mathrm{ft}^{3}\right)$ & 0 & 0 & & \\
\hline Hazardous & & & \multirow{3}{*}{$\begin{array}{l}\text { Paint, } \\
\text { hydraulic } \\
\text { oil, batteries, } \\
\text { fluorescent } \\
\text { light tubes }\end{array}$} & \multirow{3}{*}{$\begin{array}{l}\text { On-site permitted } \\
\text { storage and } \\
\text { treatment }\end{array}$} \\
\hline Liquid, L (gal) & $500(132)$ & $1,500(396)$ & & \\
\hline Solid, $\mathrm{m}^{3}\left(\mathrm{ft}^{3}\right)$ & $10(353)$ & $30(1,059)$ & & \\
\hline \multicolumn{5}{|l|}{$\begin{array}{l}\text { Nonhazardous } \\
\text { (sanitary) }\end{array}$} \\
\hline Liquid, L (gal) & $\begin{array}{c}6.50 \times 10^{6} \\
\left(1.72 \times 10^{6}\right)\end{array}$ & $\begin{array}{c}1.95 \times 10^{7} \\
\left(5.13 \times 10^{6}\right)\end{array}$ & \multirow{2}{*}{$\begin{array}{l}\text { Sewage, } \\
\text { concrete, } \\
\text { steel, lumber }\end{array}$} & \multirow[t]{2}{*}{$\begin{array}{l}\text { Sanitary sewer, } \\
\text { landfill disposal }\end{array}$} \\
\hline Solid, $\mathrm{m}^{3}\left(\mathrm{ft}^{3}\right)$ & $1,700(60,027)$ & $\begin{array}{c}5,100 \\
(180,081)\end{array}$ & & \\
\hline \multicolumn{5}{|l|}{$\begin{array}{l}\text { Nonhazardous } \\
\text { (other) }\end{array}$} \\
\hline Liquid, L (gal) & 0 & 0 & \multirow[t]{2}{*}{ - } & \multirow[t]{2}{*}{ - } \\
\hline Solid, $\mathrm{m}^{3}\left(\mathrm{ft}^{3}\right)$ & 0 & 0 & & \\
\hline
\end{tabular}


Table 7-2. Air emissions during construction.

\begin{tabular}{|l|c|}
\hline \multicolumn{1}{|c|}{ Pollutant } & Annual emissions, tonne (tons) \\
\hline Carbon monoxide & $4.55(5.0)$ \\
\hline Oxides of nitrogen $\left(\mathrm{NO}_{\mathrm{x}}\right)$ & $11.75(12.93)$ \\
\hline Particulate matter $(\mathrm{PM}-10)$ & $0.899(0.989)$ \\
\hline Oxides of sulfur $\left(\mathrm{SO}_{\mathrm{x}}\right)$ & $1.19(1.31)$ \\
\hline Volatile organic compounds & $0.93(1.02)$ \\
\hline Other regulated pollutants & $0(0)$ \\
\hline Hazardous air pollutants & $0(0)$ \\
\hline
\end{tabular}

Note: Emissions factors are based on EPA's AP-42.

Table 7-3. Radioactive releases from construction.

\begin{tabular}{|l|c|c|c|}
\hline \multicolumn{1}{|c|}{ Radionuclide } & $\begin{array}{c}\text { Release, } \\
\text { GBq/y (Ci/y) }\end{array}$ & $\begin{array}{c}\text { Average release } \\
\text { height, } \mathbf{m}(\mathbf{f t})\end{array}$ & $\begin{array}{c}\text { Release point } \\
\text { coordinates } \\
\text { (lat./long.) }\end{array}$ \\
\hline Air & 0 & - & - \\
\hline Surface water & 0 & - & - \\
\hline
\end{tabular}

Note: No incremental release from immobilization activity.

\subsection{Wastes and Emissions During Operation}

This section describes the wastes, effluents, emissions, and radioactive releases arising from operation of the facility. The data are shown in Tables 7-4 to 7-6.

\subsubsection{Solid and Liquid Wastes}

7.2.1.1 Transuranic Wastes. TRU waste will consist primarily of job-control waste, metal cladding from plutonium oxide and alloy fuel elements, HEPA filters, cans, and failed equipment. There will be some liquid lab waste, which will be treated and solidified. The TRU waste will be stored on-site, certified, and eventually shipped to WIPP.

7.2.1.2 Low Level Wastes. LLW will include job-control waste, combustibles, filters, and glass. The LLW will be transported to LLW vaults at SRS for disposal. Any liquid effluent (none expected) will be treated by existing SRS systems. 
Table 7-4. Estimated waste generation during operation.

\begin{tabular}{|c|c|c|c|c|}
\hline Waste category & $\begin{array}{l}\text { Annual } \\
\text { volume }\end{array}$ & $\begin{array}{c}\text { Total } \\
\text { estimated } \\
\text { volume }\end{array}$ & Description & $\begin{array}{l}\text { Anticipated treatment } \\
\text { method }\end{array}$ \\
\hline $\begin{array}{l}\text { Transuranic } \\
\text { Liquid, L (gal) } \\
\text { Solid, } \mathrm{m}^{3}\left(\mathrm{ft}^{3}\right)\end{array}$ & $\begin{array}{c}760(202) \\
125(4,414)\end{array}$ & $\begin{array}{c}7,600(2,020) \\
1,250(44,140)\end{array}$ & $\begin{array}{l}\text { Liquid lab waste, } \\
\text { ZPPR fuel cladding, } \\
\text { FFTF fuel rods, } \\
\text { combustibles, glass, } \\
\text { filters, job-control } \\
\text { waste, failed process } \\
\text { equipment }\end{array}$ & $\begin{array}{l}\text { Liquid waste discharged } \\
\text { to tank farm and } \\
\text { evaporated prior to } \\
\text { DWPF. Solid waste } \\
\text { packaged and stored in } \\
\text { aboveground storage on- } \\
\text { site until shipped to } \\
\text { WIPP. }\end{array}$ \\
\hline $\begin{array}{l}\text { Low level } \\
\text { Liquid, L (gal) } \\
\text { Solid, } \mathrm{m}^{3}\left(\mathrm{ft}^{3}\right)\end{array}$ & $\begin{array}{c}0(0) \\
80(2,825)\end{array}$ & $\begin{array}{c}0(0) \\
800(28,250)\end{array}$ & $\begin{array}{l}\text { Combustibles, filters, } \\
\text { gloves, glass }\end{array}$ & $\begin{array}{l}\text { Compacted, packaged, } \\
\text { and stored in aboveground } \\
\text { low level storage vaults } \\
\text { on-site. }\end{array}$ \\
\hline $\begin{array}{l}\text { Mixed LLW } \\
\text { Liquid, L (gal) } \\
\text { Solid, } \mathrm{m}^{3}\left(\mathrm{ft}^{3}\right)\end{array}$ & $\begin{array}{l}0(0) \\
1(35)\end{array}$ & $\begin{array}{c}0(0) \\
10(350)\end{array}$ & $\begin{array}{l}\text { Failed equipment, } \\
\text { grease, leaded } \\
\text { shielding }\end{array}$ & $\begin{array}{l}\text { Packaged and stored in } \\
\text { aboveground mixed, low } \\
\text { level storage vaults on- } \\
\text { site. }\end{array}$ \\
\hline $\begin{array}{l}\text { Hazardous } \\
\text { Liquid, L (gal) } \\
\text { Solid, } \mathrm{m}^{3}\left(\mathrm{ft}^{3}\right)\end{array}$ & $\begin{array}{c}4,500 \\
(1,191) \\
25(883)\end{array}$ & $\begin{array}{c}45,000 \\
(11,910) \\
250(8,830)\end{array}$ & $\begin{array}{l}\text { Chemicals, } \\
\text { lubrication oils, } \\
\text { paint, radiographic } \\
\text { wastes, batteries, } \\
\text { fluorescent light tubes }\end{array}$ & $\begin{array}{l}\text { Thermal decomposition, } \\
\text { packaged and stored in } \\
\text { aboveground mixed, low } \\
\text { level storage vaults on- } \\
\text { site. }\end{array}$ \\
\hline $\begin{array}{l}\text { Nonhazardous } \\
\text { (sanitary) } \\
\text { Liquid, L (gal) } \\
\text { Solid, } \mathrm{m}^{3}\left(\mathrm{ft}^{3}\right)\end{array}$ & $\begin{array}{l}1.96 \times 10^{7} \\
\left(5.18 \times 10^{6}\right) \\
230(8,122)\end{array}$ & $\begin{array}{c}1.96 \times 10^{8} \\
\left(5.18 \times 10^{7}\right) \\
2,300(81,220)\end{array}$ & $\begin{array}{l}\text { Sanitary sewage, } \\
\text { filters, FFTF fuel } \\
\text { housing, office and } \\
\text { shop waste }\end{array}$ & $\begin{array}{l}\text { Liquid wastes discharged } \\
\text { to sanitary sewer. Solid } \\
\text { wastes deposited in } \\
\text { landfill. }\end{array}$ \\
\hline $\begin{array}{l}\text { Nonhazardous } \\
\text { (other) } \\
\text { Liquid, L (gal) } \\
\text { Solid, tonne (ton) }\end{array}$ & $\begin{array}{c}8.02 \times 10^{6} \\
\left(2.12 \times 10^{6}\right) \\
30(34.4)\end{array}$ & $\begin{array}{c}8.02 \times 10^{7} \\
\left(2.12 \times 10^{7}\right) \\
300(344)\end{array}$ & $\begin{array}{l}\text { Cooling tower blow- } \\
\text { down, coal ash }\end{array}$ & $\begin{array}{l}\text { Blowdown water } \\
\text { discharged to permitted } \\
\text { outfall. Ash deposited in } \\
\text { landfill. }\end{array}$ \\
\hline
\end{tabular}

Notes:

- Clean metal material less than 9.07 tonnes (10 tons) per year will be recycled.

- TRU waste volume assumes about $10 \%$ annual equipment failure rate. This volume also includes waste from annual glovebox glove changeout.

- Nonhazardous sanitary waste based on DOE standards.

- Nonhazardous (other) solid waste is coal ash, estimated at 7\% of coal weight. 
Table 7-5(a). Powerhouse air emissions during operation.

\begin{tabular}{|c|c|c|}
\hline Pollutant & $\begin{array}{c}\text { Annual emissions, } \\
\text { tonne (ton) }\end{array}$ & $\begin{array}{c}\text { Average concentration, } \\
\mathrm{mg} / \mathrm{m}^{3}\left(\mathrm{lb} / \mathrm{f}^{3}\right)\end{array}$ \\
\hline Carbon monoxide & $0.14(0.150)$ & $0.3546\left(2.2 \times 10^{-8}\right)$ \\
\hline Oxides of nitrogen $\left(\mathrm{NO}_{\mathrm{x}}\right)$ & $4.54(5.00)$ & $11.528\left(7.2 \times 10^{-7}\right)$ \\
\hline Particulate matter (PM-10) & $0.35(0.385)$ & $0.887\left(5.5 \times 10^{-8}\right)$ \\
\hline Oxides of sulfur $\left(\mathrm{SO}_{\mathrm{x}}\right)$ & $13.27(14.63)$ & $33.698\left(2.1 \times 10^{-6}\right)$ \\
\hline Volatile organic compounds & $0.03(0.0385)$ & $0.0887\left(5.5 \times 10^{-9}\right)$ \\
\hline
\end{tabular}

Notes:

- Stack release coordinates: $81^{\circ} 44^{\prime} 30^{\prime \prime} \mathrm{W}$ longitude, $33^{\circ} 12^{\prime} 0^{\prime \prime} \mathrm{N}$ latitude.

- Stack height: $38.1 \mathrm{~m}(125 \mathrm{ft})$.

- Volumetric flow: $76 \mathrm{~m}^{3} / \mathrm{s}\left(2.7 \times 10^{3} \mathrm{ft}^{3} / \mathrm{s}\right)$.

- Stack cross-sectional area: $7.124 \mathrm{~m}^{2}\left(77 \mathrm{ft}^{2}\right)$.

- Exit velocity: $10.67 \mathrm{~m} / \mathrm{s}(35 \mathrm{ft} / \mathrm{s})$.

- Exit temperature: $160^{\circ} \mathrm{C}\left(320^{\circ} \mathrm{F}\right)$.

Table 7-5(b). Diesel air emissions during operation.

\begin{tabular}{|l|c|}
\hline \multicolumn{1}{|c|}{ Pollutant } & Annual emissions, tonne (ton) \\
\hline Carbon monoxide & $0.39(0.430)$ \\
\hline Oxides of nitrogen $\left(\mathrm{NO}_{\mathrm{x}}\right)$ & $1.81(1.996)$ \\
\hline Particulate matter $(\mathrm{PM}-10)$ & $0.13(0.143)$ \\
\hline Oxides of sulfur $\left(\mathrm{SO}_{\mathrm{x}}\right)$ & $0.12(0.132)$ \\
\hline Volatile organic compounds & $0.15(0.165)$ \\
\hline
\end{tabular}

Note: Diesel generator emissions are based on EPA's AP-42 per 1000 liters of diesel fuel burned.

Table 7-5(c). Process air emissions during operation.

\begin{tabular}{|l|c|}
\hline \multicolumn{1}{|c|}{ Pollutant } & Annual emissions, tonne (ton) \\
\hline Carbon monoxide & $0(0)$ \\
\hline Oxides of nitrogen $\left(\mathrm{NO}_{\mathrm{x}}\right)$ & $0(0)$ \\
\hline Particulate matter $(\mathrm{PM}-10)$ & $0(0)$ \\
\hline Oxides of sulfur $\left(\mathrm{SO}_{\mathrm{x}}\right)$ & $0(0)$ \\
\hline Volatile organic compounds & $0(0)$ \\
\hline
\end{tabular}


Table 7-6. Radioactive releases during operation.

\begin{tabular}{|c|c|c|c|}
\hline Radionuclide & $\begin{array}{c}\text { Release, } \\
\mathrm{kBq} / \mathrm{y}(\mu \mathrm{Ci} / \mathrm{y})\end{array}$ & $\begin{array}{c}\text { Average } \\
\text { release height, } \\
\text { m (ft) }\end{array}$ & $\begin{array}{l}\text { Release point } \\
\text { coordinates } \\
\text { (lat./long.) }\end{array}$ \\
\hline Air & & \multirow{9}{*}{$\begin{array}{l}59(195) \\
\text { for all process } \\
\text { releases }\end{array}$} & \multirow{9}{*}{$\begin{array}{c}33^{\circ} 17^{\prime} 30^{\prime \prime} \mathrm{N} / \\
81^{\circ} 40^{\prime} 14^{\prime \prime} \mathrm{W} \\
\text { for all process } \\
\text { releases }\end{array}$} \\
\hline${ }^{241} \mathrm{~A} \mathrm{~m}$ & $184(4.96)$ & & \\
\hline${ }^{238} \mathrm{Pu}$ & $19(0.52)$ & & \\
\hline${ }^{239} \mathrm{Pu}$ & $318(8.59)$ & & \\
\hline${ }^{240} \mathrm{Pu}$ & $105(2.85)$ & & \\
\hline${ }^{241} \mathrm{Pu}$ & $3,428(92.64)$ & & \\
\hline${ }^{242} \mathrm{Pu}$ & $5.5 \times 10^{-2}\left(1.48 \times 10^{-3}\right)$ & & \\
\hline${ }^{235} \mathrm{U}$ & $8.5 \times 10^{-5} \quad\left(2.3 \times 10^{-6}\right)$ & & \\
\hline${ }^{238} \mathrm{U}$ & $6.9 \times 10^{-4}\left(1.85 \times 10^{-5}\right)$ & & \\
\hline Surface water & & & \\
\hline No releases & & & \\
\hline
\end{tabular}

Notes:

- $\quad$ Total release $=4.1 \times 10^{3} \mathrm{kBq} / \mathrm{y}(110 \mu \mathrm{Ci} / \mathrm{y})$.

- Volumetric flow: $100 \mathrm{~m}^{3} / \mathrm{s}\left(3.5 \times 10^{3} \mathrm{cfs}\right)$.

- Stack cross-sectional area: $13.3 \mathrm{~m}^{2}\left(143 \mathrm{ft}^{2}\right)$.

- Exit velocity: $7 \mathrm{~m} / \mathrm{s}(23 \mathrm{ft} / \mathrm{s})$.

- Exit temperature: $35^{\circ} \mathrm{C}\left(95^{\circ} \mathrm{F}\right)$.

- Air emissions are based on the following assumptions:

$1 \%$ of material inside a glovebox is outside of containment (vessel, can, etc.).

$1 \%$ of the material outside of containment is dispersible.

Two stages of HEPA filtration at $99.97 \%$ efficiency prior to discharge to stack.

Isotopic distribution of feed material is:

$\begin{array}{ll}{ }^{238} \mathrm{Pu} & 0.02 \% \\ { }^{239} \mathrm{Pu} & 90.96 \% \\ { }^{240} \mathrm{Pu} & 8.2 \% \\ { }^{241} \mathrm{Pu} & 0.58 \% \\ { }^{242} \mathrm{Pu} & 0.25 \% \\ { }^{241} \mathrm{Am} & 0.94 \% \text { by weight of plutonium } \\ { }^{235} \mathrm{U} & 2.0 \% \\ { }^{238} \mathrm{U} & 98.0 \%\end{array}$

7.2.1.3 Mixed Low Level Wastes. Mixed LLW will include items similar to those described for low level solid waste and their disposition will be similar.

7.2.1.4 Hazardous Wastes. Operations will generate hazardous wastes such as spent lab chemicals and radiographic film solutions. Maintenance work may generate wastes such as lubricants, solvents, paints, coolants, and batteries. These 
hazardous wastes will be treated and disposed of in accordance with EPA RCRA guidelines at an SRS facility and shipped to an off-site vendor facility.

7.2.1.5 Nonhazardous Wastes. The nonhazardous waste generated during operation of the facility will include liquids and solids. Liquid sanitary wastes will be sent to the existing sanitary sewer. Solid waste such as office and shop trash will be sent to a sanitary landfill. Cooling tower blowdown and condensates will be treated, if necessary, and discharged or recycled. Solid coal ash will be generated at the powerhouse and disposed of in a landfill.

\subsubsection{Emissions}

Gaseous emissions from operations include exhaust gases from the powerhouse and engine emissions from the diesel generator and vehicles. Pollutant emissions from the powerhouse and engines are based on the estimated amount of fuel consumed.

Emissions, glovebox ventilation, and room exhaust air will flow through a HEPA filtration system and discharge to atmosphere through a stack. Routine releases of radioactivity from the facility shall meet the requirements established in DOE orders and shall be as low as reasonably achievable. DOE orders require that the exposure of members of the public to radiation sources as a consequence of routine DOE activities shall not cause an annual effective dose equivalent greater than $0.5 \mathrm{mSv}$ (50 mrem). Derived air concentrations for air and water effluents based on this dose are found in 10CFR20. 
UCRL-ID-128271 


\subsection{Accident Analysis}

\subsection{Accident Analysis and Risk Assessment}

The PIP is a Hazard Category 2 facility as defined in DOE-STD-1027-92. As such, it will require a detailed safety analysis report and risk assessment under DOE Order 5480.23 and DOE-STD-3009-94. This section presents a preliminary set of accidents postulated for the PIP. The description of the bounding accidents includes the following elements:

- A description of the accident scenario.

- An estimate of the frequency of the scenario. This estimate is based on engineering judgment because the design of the PIP is not advanced enough to justify use of rigorous risk analysis techniques.

- An estimate of the amount of radioactive material at risk (MAR) in the accident based on the block flow diagrams and the associated equipment.

- An estimate of the fraction of MAR that becomes airborne in respirable form based on the material in DOE-HDBK-3010-94.

- An estimate of the fraction of material airborne in respirable form that is removed by filtration of the ventilation system effluents.

\subsection{Accident Description}

Five general types of accidents were considered when evaluating the immobilization processes. Those postulated accidents were natural phenomena, externally induced failures, high energetic events, medium energetic events and low energetic events.

\subsubsection{Natural Phenomena}

The only natural phenomenon discussed in the SRS F-Canyon SAR that results in a radiological release is the Design Base Earthquake (DBE), which corresponds to $0.25 \mathrm{~g}$ ground acceleration. For the SRS area, these earthquakes occur at a frequency of $2 \times 10^{-4} / \mathrm{y}$. The release sequence for an earthquake is the loss of radioactive material to the secondary confinement, with subsequent release through the building's operating filtration and ventilation system. 


\subsubsection{Externally Induced Failures}

Most safety-related occurrences result from failures within the system, or from some action intentionally directed toward the system. It is possible however, for damage to be inflicted on a system as a result of some occurrence in a separate system. Two sources of externally induced failure mechanisms are identified as applicable to immobilization operations: natural phenomena and external impact. The natural phenomena mechanisms are discussed in Section 8.5.4.

The external impact mechanism reviewed was an aircraft crash. The structure of the buildings prevents significant damage from small aircraft and/or helicopters. Studies related to power reactors based on U.S. civil aviation accident data indicate that the expected frequency of aircraft crashes becomes essentially constant at distances greater than five miles from an airport runway. The frequency for crash of a "fixed wing" aircraft is $5.0 \times 10^{-8}$ per year, and $6.6 \times 10^{-7}$ per year for a "rotary wing" aircraft. Therefore, an aircraft crash is considered to be an incredible event.

\subsubsection{High Energetic Events}

A high energetic event is defined as one that releases sufficient energy to destroy the first confinement barrier. It will also damage the secondary confinement barrier, allowing radioactive materials to directly reach rooms occupied by personnel, or reach the environment outside the facility. No currently identified events meet this description of a high energetic event for the immobilization processes.

\subsubsection{Medium Energetic Events}

A medium energetic event is defined as one that will cause penetration of the primary confinement barrier, and could cause materials to bypass the second confinement barrier for a short period of time. Sixteen medium energetic events are applicable to operations associated with the immobilization processes.

\subsubsection{Low Energetic Events}

A low energetic event is defined as an event that will not destroy the primary confinement barrier, but may penetrate it. Four currently identified events meet this description of a low energetic event for the immobilization processes. These involve can and/or canister handling. Additionally, given the nature of the processes and the physical form of the materials involved, the low energetic events and their associated consequences are bounded by those of the natural phenomena and medium energetic accidents. 


\subsection{Accident Sequences}

The accident analysis in an EIS refers to the frequency of the consequences occurring (Table 8-1), not the frequency of the initiating event occurring. Failure scenarios include initiating event frequencies as well as failure frequencies for accident mitigating systems. The mitigating systems are provided in response to DOE requirements. For the transfer, storage, and treatment facilities, an airborne release confinement system would be provided to mitigate accident scenarios. It is assumed that confinement filtering is credited in the scenarios.

Table 8-1. Frequency evaluation ranges.

\begin{tabular}{|l|c|}
\hline \multicolumn{1}{|c|}{ Description } & Frequency range per year \\
\hline Anticipated (A) & $>10^{-2}$ \\
\hline Unlikely (U) & $10^{-4}-10^{-2}$ \\
\hline Extremely unlikely (EU) & $10^{-6}-10^{-4}$ \\
\hline Beyond extremely unlikely (BEU) & $<10^{-6}$ \\
\hline
\end{tabular}

Confinement filtering is credited in the scenarios for retaining $99.999 \%$ of the particulates but none of the noble gases. That is, the probability is 1.0 that all the noble gases and $0.001 \%$ of all the particulates will be carried by the ventilation system through the HEPA filters and released to the environment via the stack.

The isotopic distribution for the source term calculations for plutonium conversion accident scenarios, except for the vault criticality accident, are found in the footnote to Table A-5 in Appendix A. The isotopic distribution for the vault criticality accident and all first-stage immobilization accident scenarios are found in the footnote to Table 7-6, Section 7.0.

\subsection{Plutonium Conversion Accident Sequences}

\subsubsection{Criticality in Halide Wash Accident}

Impure plutonium oxides that are mixed with halides must be ground and washed to remove the salts. The raffinate material containing the salt will be evaporated and disposed of as liquid waste. The plutonium oxide solids will be filtered and dried prior to calcining. It is assumed that a separate halide wash glovebox is used because of the introduction of an aqueous solution to the process. A criticality accident may occur with a water intrusion on the plutonium oxide powder due to mechanical failure. Or human error could cause a double batching of oxide material in the halide wash glovebox. In this case, sufficient material would 
accumulate, with insufficient neutron absorbers to prevent a criticality. This medium energetic event will cause penetration of the primary confinement barrier, the halide wash glovebox. "Double contingency" principles would require independent controls or independent verification of administrative controls that would limit the amount of oxide solids in the wash process. The effects of a criticality event would be mitigated by shielding and the physical distance of the operators in remote handling operations. The criticality alarm system and facility evacuation procedures are an important mitigating feature for facility workers.

The primary operator performing the batching operations could be assumed to make an error if procedures are not followed.

The probability of having a criticality accident and releasing radionuclides past the filtration system and into the environment is $5 \times 10^{-6} / \mathrm{y}$, which is in the "extremely unlikely" range (Table 8-1). This frequency is much less than the frequency of $1.6 \times 10^{-3} / \mathrm{y}$ for a criticality due to uranium or plutonium in any of the SRS H-Canyon process tanks. On the other hand, if a dedicated operator provides continuous participation as a checker (not a supervisor) in following every step of the operation, this probability could be reduced by a factor of ten.

The fission yield source term was based on the criticality source term reported in the SRS F-Canyon Safety Analysis. For conservatism, $1 \times 10^{19}$ fissions were assumed versus the $2 \times 10^{18}$ fissions reported in the SRS F-Canyon Safety Analysis. The airborne release fraction (ARF), respirable fraction (RF), and damage ratio (DR) were obtained from DOE-HDBK-3010-94. This handbook states that "Due to the size of individual particles in a powder, it is assumed that the fraction of volatile fission products (noble gases, iodine, ruthenium) present are so close to the surface that they are released ...." Therefore, the DR would be 1.0. Table 8-2 reflects the source term associated with the noble gases and volatile radioisotopes for this event. For conservatism and due to the energy associated with $1 \times 10^{19}$ fissions, it is assumed that non-volatile radioisotopes will be released with the same RFs as the volatile nuclides. Table 8-3 reflects the source term for the non-volatile radioisotopes in this event.

\subsubsection{Criticality in HYDOX Furnace}

Conversion of plutonium metal is accomplished using the HYDOX process. The basic HYDOX process consists of two chambers, one where metal is charged and hydrogen gas is introduced, and another that is heated by the HYDOX furnace. Criticality may result when a "double batch" of material is moved into the furnace glovebox or an operator inadvertently leaves fissile material behind in the glovebox before bringing in another batch. Human error would allow sufficient material for a critical mass to accumulate with insufficient neutron absorbers to prevent a 
criticality. "Double contingency" principles would require independent controls or independent verification of administrative controls to ensure that batch operations be limited to only one can at a time. It is assumed that the glovebox (including the window) will maintain its structural integrity and that the internal HEPA filter will entrain the radionuclides. It is assumed that this medium energetic event will cause penetration of the primary confinement barrier (the HYDOX furnace glovebox), but that the double HEPA filtration (the process room filtration external to the glovebox) does not fail and provides filtration prior to discharge to the stack. The criticality alarm system and facility evacuation procedures are an important mitigating feature for facility workers.

Table 8-2. Fission yield from $1 \times 10^{19}$ fissions in an oxide powder.

\begin{tabular}{|l|c|c|c|}
\hline Radionuclide & $\begin{array}{c}\text { MAR Fission Product, GBq } \\
\text { (Ci) }\end{array}$ & $\begin{array}{c}\text { Airborne Release Fraction } \\
\text { (ARF) }\end{array}$ & $\begin{array}{c}\text { Fission Yield Source } \\
\text { Term, GBq (Ci) }\end{array}$ \\
\hline Br83 & $1.70 \times 10^{3}\left(4.60 \times 10^{1}\right)$ & $5.00 \times 10^{-2}$ & $8.51 \times 10^{1}\left(2.30 \times 10^{0}\right)$ \\
\hline Br84 & $1.30 \times 10^{4}\left(3.50 \times 10^{2}\right)$ & $5.00 \times 10^{-2}$ & $6.48 \times 10^{2}\left(1.75 \times 10^{1}\right)$ \\
\hline Kr83m & $9.44 \times 10^{2}\left(2.55 \times 10^{1}\right)$ & $5.00 \times 10^{-1}$ & $4.74 \times 10^{2}\left(1.28 \times 10^{1}\right)$ \\
\hline Kr85m & $2.22 \times 10^{3}\left(6.00 \times 10^{1}\right)$ & $5.00 \times 10^{-1}$ & $1.11 \times 10^{3}\left(3.00 \times 10^{1}\right)$ \\
\hline Kr87 & $1.41 \times 10^{4}\left(3.80 \times 10^{2}\right)$ & $5.00 \times 10^{-1}$ & $7.03 \times 10^{3}\left(1.90 \times 10^{2}\right)$ \\
\hline Kr88 & $4.07 \times 10^{4}\left(1.10 \times 10^{3}\right)$ & $5.00 \times 10^{-1}$ & $2.04 \times 10^{4}\left(5.50 \times 10^{2}\right)$ \\
\hline Ru105 & $2.04 \times 10^{4}\left(5.50 \times 10^{2}\right)$ & $2.00 \times 10^{-3}$ & $4.07 \times 10^{1}\left(1.10 \times 10^{0}\right)$ \\
\hline I131 & $3.15 \times 10^{2}\left(8.50 \times 10^{0}\right)$ & $5.00 \times 10^{-2}$ & $1.57 \times 10^{1}\left(4.25 \times 10^{-1}\right)$ \\
\hline I132 & $2.59 \times 10^{3}\left(7.00 \times 10^{1}\right)$ & $5.00 \times 10^{-2}$ & $1.30 \times 10^{2}\left(3.50 \times 10^{0}\right)$ \\
\hline I133 & $5.55 \times 10^{3}\left(1.50 \times 10^{2}\right)$ & $5.00 \times 10^{-2}$ & $2.78 \times 10^{2}\left(7.50 \times 10^{0}\right)$ \\
\hline I134 & $7.03 \times 10^{4}\left(1.90 \times 10^{3}\right)$ & $5.00 \times 10^{-2}$ & $3.52 \times 10^{3}\left(9.50 \times 10^{1}\right)$ \\
\hline I135 & $1.85 \times 10^{4}\left(5.00 \times 10^{2}\right)$ & $5.00 \times 10^{-2}$ & $9.25 \times 10^{2}\left(2.50 \times 10^{1}\right)$ \\
\hline Te134 & $1.09 \times 10^{5}\left(2.95 \times 10^{3}\right)$ & $7.00 \times 10^{-2}$ & $7.66 \times 10^{3}\left(2.07 \times 10^{2}\right)$ \\
\hline Xe133 & $3.33 \times 10^{2}\left(9.00 \times 10^{0}\right)$ & $5.00 \times 10^{-1}$ & $1.67 \times 10^{2}\left(4.50 \times 10^{0}\right)$ \\
\hline Xe135 & $5.92 \times 10^{3}\left(1.60 \times 10^{2}\right)$ & $5.00 \times 10^{-1}$ & $2.96 \times 10^{3}\left(8.00 \times 10^{1}\right)$ \\
\hline Xe135m & $2.04 \times 10^{4}\left(5.50 \times 10^{2}\right)$ & $5.00 \times 10^{-1}$ & $1.02 \times 10^{4}\left(2.75 \times 10^{2}\right)$ \\
\hline Xe138 & $2.59 \times 10^{5}\left(7.00 \times 10^{3}\right)$ & $5.00 \times 10^{-1}$ & $1.30 \times 10^{5}\left(3.50 \times 10^{3}\right)$ \\
\hline & & & $1.85 \times 10^{5}\left(5.00 \times 10^{3}\right)$ \\
\hline Total & $5.85 \times 10^{5}\left(1.58 \times 10^{4}\right)$ & & \\
\hline
\end{tabular}

Notes:

- For the criticality in the halide wash, the NPH vault criticality, and the criticality in the rotary splitter.

- The leak path factor is 1.0.

- The damage ratio is 1.0 .

- The respirable fraction is 1.0.

- DOE-HDBK-3010-94 page reference: Sec 6.3.2, page 6-23. 
Table 8-3. Halide wash criticality non-volatile source term.

\begin{tabular}{|l|c|c|c|c|c|c|}
\hline Radionuclide & $\begin{array}{c}\text { MAR } \\
\text { Inventory, } \\
\text { kg (lb) }\end{array}$ & $\begin{array}{c}\text { Leak Path } \\
\text { Factor } \\
\text { (LPF) }\end{array}$ & $\begin{array}{c}\text { Damage } \\
\text { Ratio } \\
\text { (DR) }\end{array}$ & $\begin{array}{c}\text { Airborne } \\
\text { Release } \\
\text { Fraction } \\
\text { (ARF) }\end{array}$ & $\begin{array}{c}\text { Respirable } \\
\text { Fraction } \\
\text { (RF) }\end{array}$ & DOE-HDBK-3010-94 Ref. \\
\hline Pu239 & & $1.00 \times 10^{-5}$ & 1 & $4 \times 10^{-4}$ & 1 & Sec. 6.3.2, pg 6-23 \\
\hline Pu240 & & $1.00 \times 10^{-5}$ & 1 & $4 \times 10^{-4}$ & 1 & Sec. 6.3.2, pg 6-23 \\
\hline Pu241 & & $1.00 \times 10^{-5}$ & 1 & $4 \times 10^{-4}$ & 1 & Sec. 6.3.2, pg 6-23 \\
\hline Pu242 & & $1.00 \times 10^{-5}$ & 1 & $4 \times 10^{-4}$ & 1 & Sec. 6.3.2, pg 6-23 \\
\hline Am241 & & $1.00 \times 10^{-5}$ & 1 & $6 \times 10^{-4}$ & 1 & Sec. 6.3.2, pg 6-23 \\
\hline Pu /Am Subtotal & $0.5(1.1)$ & & & & & \\
\hline
\end{tabular}

Note: Halide wash includes only plutonium material. Therefore, the uranium isotopics found in the referenced table are not included.

The primary operator performing the batching operations in the HYDOX glovebox could be assumed to make an error if procedures are not followed.

The probability of having a criticality accident and releasing radionuclides past the filtration system and into the environment is $2.5 \times 10^{-5} / \mathrm{y}$, which is in the "extremely unlikely" range (Table 8-1). This frequency is less than the frequency of $1.6 \times 10^{-3} / \mathrm{y}$ for a criticality due to uranium or plutonium in any of the SRS $\mathrm{H}$-Canyon process tanks.

The fission yield source term was based on the criticality source term reported in the SRS F-Canyon Safety Analysis. For conservatism $1 \times 10^{19}$ fissions were assumed versus the $2 \times 10^{18}$ fissions reported in the SRS F-Canyon Safety Analysis. The ARF, $\mathrm{RF}$, and DR were obtained from DOE-HDBK-3010-943. The MAR is assumed to be twice the daily inventory for all HYDOX furnaces and to be in a metal form. Therefore, the DR would be $10 \%$. Table $8-4$ reflects the fission yield source term for this event and Table 8-5 reflects the source term component due to melting or softening of the metal.

\subsubsection{Criticality in Sorting/Unpackaging Glovebox}

Criticality may result when more than one can is moved from the "hot" working vault to be unpackaged within the unpackaging glovebox, or when an operator inadvertently leaves fissile material in the glovebox before opening another container. Before it is opened, the containment vessel holding the radionuclide material is moved into the unpackaging glovebox to ensure confinement in case of a breach of one of the containers. Human error, such as opening several containers concurrently, would allow sufficient material to be placed in proximity to one another to cause a criticality. "Double contingency" principles would require independent controls or independent verification of administrative controls that 
Table 8-4. Fission yield from $1 \times 10^{19}$ fissions in a metal.

\begin{tabular}{|c|c|c|c|c|}
\hline Radionuclide & $\begin{array}{c}\text { MAR } \\
\text { Fission Product, } \\
\text { GBq (Ci) }\end{array}$ & $\begin{array}{l}\text { Leak Path } \\
\text { Factor } \\
\text { (LPF) }\end{array}$ & $\begin{array}{c}\text { Airborne Release } \\
\text { Fraction } \\
\text { (ARF) }\end{array}$ & $\begin{array}{c}\text { Fission Yield } \\
\text { Source Term , } \\
\text { GBq (Ci) }\end{array}$ \\
\hline Br83 & $1.70 \times 10^{3}\left(4.60 \times 10^{1}\right)$ & 1 & $5.00 \times 10^{-2}$ & $8.51 \times 10^{0}\left(2.30 \times 10^{-1}\right)$ \\
\hline $\mathrm{Br} 84$ & $1.30 \times 10^{4}\left(3.50 \times 10^{2}\right)$ & 1 & $5.00 \times 10^{-2}$ & $6.48 \times 10^{1}\left(1.75 \times 10^{0}\right)$ \\
\hline Kr83m & $9.44 \times 10^{2}\left(2.55 \times 10^{1}\right)$ & 1 & $5.00 \times 10^{-1}$ & $4.74 \times 10^{1}\left(1.28 \times 10^{0}\right)$ \\
\hline Kr85m & $2.22 \times 10^{3}\left(6.00 \times 10^{1}\right)$ & 1 & $5.00 \times 10^{-1}$ & $1.11 \times 10^{2}\left(3.00 \times 10^{0}\right)$ \\
\hline Kr87 & $1.41 \times 10^{4}\left(3.80 \times 10^{2}\right)$ & 1 & $5.00 \times 10^{-1}$ & $7.03 \times 10^{2}\left(1.90 \times 10^{1}\right)$ \\
\hline Kr88 & $4.07 \times 10^{4}\left(1.10 \times 10^{3}\right)$ & 1 & $5.00 \times 10^{-1}$ & $2.04 \times 10^{3}\left(5.50 \times 10^{1}\right)$ \\
\hline $\mathrm{Rb} 88$ & $2.04 \times 10^{4}\left(5.50 \times 10^{2}\right)$ & $1.00 \times 10^{-5}$ & $2.00 \times 10^{-1}$ & $4.07 \times 10^{-3}\left(1.10 \times 10^{-4}\right)$ \\
\hline $\mathrm{Rb} 89$ & $7.59 \times 10^{4}\left(2.05 \times 10^{3}\right)$ & $1.00 \times 10^{-5}$ & $2.00 \times 10^{-1}$ & $1.52 \times 10^{-2}\left(4.10 \times 10^{-4}\right)$ \\
\hline Sr91 & $5.00 \times 10^{3}\left(1.35 \times 10^{2}\right)$ & $1.00 \times 10^{-5}$ & $3.00 \times 10^{-2}$ & $1.50 \times 10^{-4}\left(4.05 \times 10^{-6}\right)$ \\
\hline Sr92 & $2.22 \times 10^{4}\left(6.00 \times 10^{2}\right)$ & $1.00 \times 10^{-5}$ & $3.00 \times 10^{-2}$ & $6.66 \times 10^{-4}\left(1.80 \times 10^{-5}\right)$ \\
\hline Y91m & $2.41 \times 10^{3}\left(6.50 \times 10^{1}\right)$ & $1.00 \times 10^{-5}$ & $6.00 \times 10^{-4}$ & $1.44 \times 10^{-6}\left(3.90 \times 10^{-8}\right)$ \\
\hline Y92 & $7.03 \times 10^{3}\left(1.90 \times 10^{2}\right)$ & $1.00 \times 10^{-5}$ & $6.00 \times 10^{-4}$ & $4.22 \times 10^{-6}\left(1.14 \times 10^{-7}\right)$ \\
\hline Y93 & $7.03 \times 10^{3}\left(1.90 \times 10^{2}\right)$ & $1.00 \times 10^{-5}$ & $6.00 \times 10^{-4}$ & $4.22 \times 10^{-6}\left(1.14 \times 10^{-7}\right)$ \\
\hline $\mathrm{Nb97}$ & $5.00 \times 10^{3}\left(1.35 \times 10^{2}\right)$ & $1.00 \times 10^{-5}$ & $3.00 \times 10^{-2}$ & $1.50 \times 10^{-4}\left(4.05 \times 10^{-6}\right)$ \\
\hline $\mathrm{Nb97m}$ & $2.22 \times 10^{4}\left(6.00 \times 10^{2}\right)$ & $1.00 \times 10^{-5}$ & $3.00 \times 10^{-2}$ & $6.66 \times 10^{-4}\left(1.80 \times 10^{-5}\right)$ \\
\hline Zr97 & $6.48 \times 10^{3}\left(1.75 \times 10^{2}\right)$ & $1.00 \times 10^{-5}$ & $4.00 \times 10^{-4}$ & $2.59 \times 10^{-6}\left(7.00 \times 10^{-8}\right)$ \\
\hline Mo99 & $1.79 \times 10^{3}\left(4.85 \times 10^{1}\right)$ & $1.00 \times 10^{-5}$ & $3.00 \times 10^{-2}$ & $5.40 \times 10^{-5}\left(1.46 \times 10^{-6}\right)$ \\
\hline Mo101 & $5.92 \times 10^{5}\left(1.60 \times 10^{4}\right)$ & $1.00 \times 10^{-5}$ & $3.00 \times 10^{-2}$ & $1.78 \times 10^{-2}\left(4.80 \times 10^{-4}\right)$ \\
\hline Tc99m & $9.07 \times 10^{2}\left(2.45 \times 10^{1}\right)$ & $1.00 \times 10^{-5}$ & $3.00 \times 10^{-2}$ & $2.72 \times 10^{-5}\left(7.35 \times 10^{-7}\right)$ \\
\hline Tc101 & $2.22 \times 10^{5}\left(6.00 \times 10^{3}\right)$ & $1.00 \times 10^{-5}$ & $3.00 \times 10^{-2}$ & $6.66 \times 10^{-3}\left(1.80 \times 10^{-4}\right)$ \\
\hline Rh105 & $2.78 \times 10^{3}\left(7.50 \times 10^{1}\right)$ & $1.00 \times 10^{-5}$ & $2.00 \times 10^{-3}$ & $5.55 \times 10^{-6}\left(1.50 \times 10^{-7}\right)$ \\
\hline Ru105 & $2.04 \times 10^{4}\left(5.50 \times 10^{2}\right)$ & $1.00 \times 10^{-5}$ & $2.00 \times 10^{-3}$ & $4.07 \times 10^{-5}\left(1.10 \times 10^{-6}\right)$ \\
\hline Ag109m & $2.22 \times 10^{3}\left(6.00 \times 10^{1}\right)$ & $1.00 \times 10^{-5}$ & $4.00 \times 10^{-3}$ & $8.88 \times 10^{-6}\left(2.40 \times 10^{-7}\right)$ \\
\hline Pd109 & $2.22 \times 10^{3}\left(6.00 \times 10^{1}\right)$ & $1.00 \times 10^{-5}$ & $2.00 \times 10^{-3}$ & $4.44 \times 10^{-6}\left(1.20 \times 10^{-7}\right)$ \\
\hline $\mathrm{Cd} 117$ & $3.52 \times 10^{2}\left(9.50 \times 10^{0}\right)$ & $1.00 \times 10^{-5}$ & $4.00 \times 10^{-3}$ & $1.41 \times 10^{-6}\left(3.80 \times 10^{-8}\right)$ \\
\hline Sb126m & $9.44 \times 10^{2}\left(2.55 \times 10^{1}\right)$ & $1.00 \times 10^{-5}$ & $4.00 \times 10^{-3}$ & $3.77 \times 10^{-6}\left(1.02 \times 10^{-7}\right)$ \\
\hline Sb129 & $4.63 \times 10^{3}\left(1.25 \times 10^{2}\right)$ & $1.00 \times 10^{-5}$ & $4.00 \times 10^{-3}$ & $1.85 \times 10^{-5}\left(5.00 \times 10^{-7}\right)$ \\
\hline Te129 & $2.96 \times 10^{3}\left(8.00 \times 10^{1}\right)$ & $1.00 \times 10^{-5}$ & $7.00 \times 10^{-2}$ & $2.07 \times 10^{-4}\left(5.60 \times 10^{-6}\right)$ \\
\hline $\mathrm{I131}$ & $3.15 \times 10^{2}\left(8.50 \times 10^{0}\right)$ & 1 & $5.00 \times 10^{-2}$ & $1.57 \times 10^{0}\left(4.25 \times 10^{-2}\right)$ \\
\hline $\mathrm{I} 132$ & $2.59 \times 10^{3}\left(7.00 \times 10^{1}\right)$ & 1 & $5.00 \times 10^{-2}$ & $1.30 \times 10^{1}\left(3.50 \times 10^{-1}\right)$ \\
\hline $\mathrm{I} 133$ & $5.55 \times 10^{3}\left(1.50 \times 10^{2}\right)$ & 1 & $5.00 \times 10^{-2}$ & $2.78 \times 10^{1}\left(7.50 \times 10^{-1}\right)$ \\
\hline $\mathrm{I} 134$ & $7.03 \times 10^{4}\left(1.90 \times 10^{3}\right)$ & 1 & $5.00 \times 10^{-2}$ & $3.52 \times 10^{2}\left(9.50 \times 10^{0}\right)$ \\
\hline $\mathrm{I} 135$ & $1.85 \times 10^{4}\left(5.00 \times 10^{2}\right)$ & 1 & $5.00 \times 10^{-2}$ & $9.25 \times 10^{1}\left(2.50 \times 10^{0}\right)$ \\
\hline Te131 & $5.00 \times 10^{4}\left(1.35 \times 10^{3}\right)$ & $1.00 \times 10^{-5}$ & $7.00 \times 10^{-2}$ & $3.50 \times 10^{-3}\left(9.45 \times 10^{-5}\right)$ \\
\hline $\mathrm{Te} 131 \mathrm{~m}$ & $6.48 \times 10^{2}\left(1.75 \times 10^{1}\right)$ & $1.00 \times 10^{-5}$ & $7.00 \times 10^{-2}$ & $4.55 \times 10^{-5}\left(1.23 \times 10^{-6}\right)$ \\
\hline Te132 & $1.30 \times 10^{3}\left(3.50 \times 10^{1}\right)$ & $1.00 \times 10^{-5}$ & $7.00 \times 10^{-2}$ & $9.07 \times 10^{-5}\left(2.45 \times 10^{-6}\right)$ \\
\hline Te133 & $1.50 \times 10^{5}\left(4.05 \times 10^{3}\right)$ & $1.00 \times 10^{-5}$ & $7.00 \times 10^{-2}$ & $1.05 \times 10^{-2}\left(2.84 \times 10^{-4}\right)$ \\
\hline Te133m & $6.48 \times 10^{4}\left(1.75 \times 10^{3}\right)$ & $1.00 \times 10^{-5}$ & $7.00 \times 10^{-2}$ & $4.55 \times 10^{-3}\left(1.23 \times 10^{-4}\right)$ \\
\hline Te134 & $1.09 \times 10^{5}\left(2.95 \times 10^{3}\right)$ & $1.00 \times 10^{-5}$ & $7.00 \times 10^{-2}$ & $7.66 \times 10^{-3}\left(2.07 \times 10^{-4}\right)$ \\
\hline Xe133 & $3.33 \times 10^{2}\left(9.00 \times 10^{0}\right)$ & 1 & $5.00 \times 10^{-1}$ & $1.67 \times 10^{1}\left(4.50 \times 10^{-1}\right)$ \\
\hline Xe135 & $5.92 \times 10^{3}\left(1.60 \times 10^{2}\right)$ & 1 & $5.00 \times 10^{-1}$ & $2.96 \times 10^{2}\left(8.00 \times 10^{0}\right)$ \\
\hline Xe135m & $2.04 \times 10^{4}\left(5.50 \times 10^{2}\right)$ & 1 & $5.00 \times 10^{-1}$ & $1.02 \times 10^{3}\left(2.75 \times 10^{1}\right)$ \\
\hline
\end{tabular}


Table 8-4 (cont.)

\begin{tabular}{|l|l|l|l|l|}
\hline Xe138 & $2.59 \times 10^{5}\left(7.00 \times 10^{3}\right)$ & 1 & $5.00 \times 10^{-1}$ & $1.30 \times 10^{4}\left(3.50 \times 10^{2}\right)$ \\
\hline Ba137m & $9.07 \times 10^{2}\left(2.45 \times 10^{1}\right)$ & $1.00 \times 10^{-5}$ & $3.00 \times 10^{-2}$ & $2.72 \times 10^{-5}\left(7.35 \times 10^{-7}\right)$ \\
\hline Ba139 & $6.48 \times 10^{4}\left(1.75 \times 10^{3}\right)$ & $1.00 \times 10^{-5}$ & $3.00 \times 10^{-2}$ & $1.94 \times 10^{-3}\left(5.25 \times 10^{-5}\right)$ \\
\hline Ba140 & $3.52 \times 10^{2}\left(9.50 \times 10^{0}\right)$ & $1.00 \times 10^{-5}$ & $3.00 \times 10^{-2}$ & $1.05 \times 10^{-5}\left(2.85 \times 10^{-7}\right)$ \\
\hline Ba141 & $2.96 \times 10^{5}\left(8.00 \times 10^{3}\right)$ & $1.00 \times 10^{-5}$ & $3.00 \times 10^{-2}$ & $8.88 \times 10^{-3}\left(2.40 \times 10^{-4}\right)$ \\
\hline Ba142 & $4.63 \times 10^{5}\left(1.25 \times 10^{4}\right)$ & $1.00 \times 10^{-5}$ & $3.00 \times 10^{-2}$ & $1.39 \times 10^{-2}\left(3.75 \times 10^{-4}\right)$ \\
\hline Cs138 & $1.09 \times 10^{5}\left(2.95 \times 10^{3}\right)$ & $1.00 \times 10^{-5}$ & $2.00 \times 10^{-1}$ & $2.18 \times 10^{-2}\left(5.90 \times 10^{-4}\right)$ \\
\hline La141 & $2.22 \times 10^{4}\left(6.00 \times 10^{2}\right)$ & $1.00 \times 10^{-5}$ & $6.00 \times 10^{-4}$ & $1.33 \times 10^{-5}\left(3.60 \times 10^{-7}\right)$ \\
\hline La142 & $5.00 \times 10^{4}\left(1.35 \times 10^{3}\right)$ & $1.00 \times 10^{-5}$ & $6.00 \times 10^{-4}$ & $3.00 \times 10^{-5}\left(8.10 \times 10^{-7}\right)$ \\
\hline Ce143 & $2.59 \times 10^{3}\left(7.00 \times 10^{1}\right)$ & $1.00 \times 10^{-5}$ & $4.00 \times 10^{-4}$ & $1.04 \times 10^{-6}\left(2.80 \times 10^{-8}\right)$ \\
\hline Pr144 & $2.59 \times 10^{2}\left(7.00 \times 10^{0}\right)$ & $1.00 \times 10^{-5}$ & $6.00 \times 10^{-4}$ & $1.55 \times 10^{-7}\left(4.20 \times 10^{-9}\right)$ \\
\hline Nd149 & $1.30 \times 10^{3}\left(3.50 \times 10^{1}\right)$ & $1.00 \times 10^{-5}$ & $6.00 \times 10^{-4}$ & $7.77 \times 10^{-7}\left(2.10 \times 10^{-8}\right)$ \\
\hline Pm151 & $2.78 \times 10^{2}\left(7.50 \times 10^{0}\right)$ & $1.00 \times 10^{-5}$ & $6.00 \times 10^{-4}$ & $1.67 \times 10^{-7}\left(4.50 \times 10^{-9}\right)$ \\
\hline Total & $2.87 \times 10^{6}\left(7.75 \times 10^{4}\right)$ & & & $1.85 \times 10^{4}\left(5.00 \times 10^{2}\right)$ \\
\hline
\end{tabular}

Notes:

- For the criticality in the HYDOX furnace and the criticality in the sorting/unpackaging glovebox.

- The damage ratio is 0.1 .

- The respirable fraction is 1.0 .

- DOE-HDBK-3010-94 page reference: Sec 6.3.2, page 6-23.

would ensure that the unpackaging operations be limited to only one container at a time. The effects of a criticality event would be mitigated by shielding and the physical distance of the operators in remote handling operations. The criticality alarm system and facility evacuation procedures are an important mitigating feature for facility workers.

The primary operator performing the unpackaging operations could be assumed to make an error if procedures are not followed.

The probability of having a criticality accident and releasing radionuclides past the filtration system and into the environment is $4 \times 10^{-5} / \mathrm{y}$, which is in the "extremely unlikely" range (Table 8-1). This frequency is less than the frequency of $1.6 \times 10^{-3} / \mathrm{y}$ for a criticality due to plutonium or uranium in any of the SRS $\mathrm{H}$-Canyon process tanks.

The fission yield source term was based on the criticality source term reported in the SRS F-Canyon Safety Analysis. For conservatism, $1 \times 10^{19}$ fissions were assumed versus the $2 \times 10^{18}$ fissions reported in the SRS F-Canyon Safety Analysis. The ARF, $\mathrm{RF}$, and DR were obtained from DOE-HDBK-3010-94. The MAR is assumed to be twice the amount of plutonium metal that is normally processed through the sorting and unpackaging glovebox. Therefore, the DR would be $10 \%$. Table $8-4$ reflects the fission yield source term for this event and Table 8-5 reflects the source term component due to melting or softening of the metal. 
Table 8-5. HYDOX furnace and sort and inspect glovebox criticality metal melt source term.

\begin{tabular}{|l|c|c|c|c|c|c|}
\hline Radionuclide & $\begin{array}{c}\text { MAR } \\
\text { Inventory, } \\
\text { kg (lb) }\end{array}$ & $\begin{array}{c}\text { Leak Path } \\
\text { Factor } \\
\text { (LPF) }\end{array}$ & $\begin{array}{c}\text { Damage } \\
\text { Ratio } \\
\text { (DR) }\end{array}$ & $\begin{array}{c}\text { Airborne } \\
\text { Release } \\
\text { Fraction } \\
\text { (ARF) }\end{array}$ & $\begin{array}{c}\text { Respirable } \\
\text { Fraction } \\
\text { (RF) }\end{array}$ & $\begin{array}{c}\text { DOE-HDBK-3010-94 } \\
\text { Ref. }\end{array}$ \\
\hline Pu239 & & $1.00 \times 10^{-5}$ & 0.1 & $4.00 \times 10^{-4}$ & 1 & Sec. 6.3.2, pg 6-23 \\
\hline Pu240 & & $1.00 \times 10^{-5}$ & 0.1 & $4.00 \times 10^{-4}$ & 1 & Sec. 6.3.2, pg 6-23 \\
\hline Pu241 & & $1.00 \times 10^{-5}$ & 0.1 & $4.00 \times 10^{-4}$ & 1 & Sec. 6.3.2, pg 6-23 \\
\hline Pu242 & & $1.00 \times 10^{-5}$ & 0.1 & $4.00 \times 10^{-4}$ & 1 & Sec. 6.3.2, pg 6-23 \\
\hline Am241 & $1.00 \times 10^{-5}$ & 0.1 & $6.00 \times 10^{-4}$ & 1 & Sec. 6.3.2, pg 6-23 \\
\hline Pu /Am Subtotal & $9.7(21)$ & & & & & \\
\hline U235 & & $1.00 \times 10^{-5}$ & 0.1 & $4.00 \times 10^{-4}$ & 1 & Sec. 6.3.2, pg 6-23 \\
\hline U238 & & $1.00 \times 10^{-5}$ & 0.1 & $4.00 \times 10^{-4}$ & 1 & Sec. 6.3.2, pg 6-23 \\
\hline U Subtotal & $7.9(17)$ & & & & & \\
\hline
\end{tabular}

\subsubsection{Explosion in HYDOX Furnace}

Conversion of plutonium metal is accomplished using the HYDOX process. The basic HYDOX system consists of two chambers, one where metal is charged and hydrogen gas is introduced, and another chamber containing a crucible that is heated by the HYDOX furnace. When air is introduced into the glovebox and the argon gas supply fails, the hydrogen gas is ignited by the HYDOX furnace, causing an explosion. The structural integrity of the furnace itself can become compromised, releasing the plutonium oxide. It is assumed that the glovebox will not maintain its structural integrity, the pressure spike from the explosion will challenge the internal HEPA filter, and the filter will not entrain the radionuclides. It is assumed that the double HEPA filtration, external to the glovebox (process room), does not fail and provides filtration prior to discharge to the stack. Engineered safety features and administrative controls mitigate the consequences of this event. Alarm response procedures and emergency response procedures guide personnel actions during this event.

Four scenarios are considered: Scenario 1A, in which the explosion is attributed to an inadvertent introduction of oxygen or some other gas that reacts adversely with the hydrogen in the furnace; Scenario 1B, in which the explosion is attributed to a leak of ambient air into the system; Scenario $2 \mathrm{~A}$, in which the explosion is attributed to the contents in the furnace; and Scenario 2B, in which the explosion is attributed to the amount of materials in the furnace.

The frequency for Scenario 1A that particulates and radionuclides will be released within the building is $1.3 \times 10^{-5} / \mathrm{y}$, which is in the "extremely unlikely" range (see Table 8-1). The frequency for Scenario $1 \mathrm{~B}$ is much lower. 
The probability of an explosion in the HYDOX furnace releasing radioactive particulates and radionuclides within the building is $5 \times 10^{-4} / \mathrm{y}$, which is in the "unlikely" range.

In Scenario 2B, the explosion is attributed to the amount of material in the furnace. There are 200 batches per year (once per day) when an explosion could occur. The operator preparing the material to go into the furnace would have to fail to obtain the correct amount of materials and a second operator actively participating in checking this process fail to catch the error. There must be enough material present to be capable of a sufficiently adverse effect, i.e., explosion. The assumptions and analysis for Scenario 2B parallel Scenario 2A such that the same frequency of $5 \times 10^{-4} / y$ is obtained again.

The sum of the frequencies for all four scenarios $(1 \mathrm{~A}, 1 \mathrm{~B}, 2 \mathrm{~A}$, and $2 \mathrm{~B})$ that particulates and radionuclides will be released within the building is $1 \times 10^{-3} / \mathrm{y}$, which remains in the "unlikely" range.

At the time of the event, the entire day's throughput for all HYDOX furnaces is present in one HYDOX furnace and is in the form of an oxide powder. Because the entire furnace inventory would be involved, a DR of 1.0 was used.

Table 8-6 shows the source term for this event and specific citations for the ARF and RF.

Table 8-6. Explosion in the HYDOX furnace source term.

\begin{tabular}{|l|c|c|c|c|c|c|}
\hline & $\begin{array}{c}\text { MAR } \\
\text { Daily } \\
\text { Inventory, } \\
\text { kg (lb) }\end{array}$ & $\begin{array}{c}\text { Leak } \\
\text { Path } \\
\text { Factor } \\
\text { (LPF) }\end{array}$ & $\begin{array}{c}\text { Damage } \\
\text { Ratio } \\
\text { (DR) }\end{array}$ & $\begin{array}{c}\text { Airborne } \\
\text { Release } \\
\text { Fraction } \\
\text { (ARF) }\end{array}$ & $\begin{array}{c}\text { Respirable } \\
\text { Fraction } \\
\text { (RF) }\end{array}$ & $\begin{array}{c}\text { DOE-HDBK-3010-94 } \\
\text { Ref. }\end{array}$ \\
\hline Pu/Am Subtotal & $4.85(10.7)$ & $1.00 \times 10^{-5}$ & 1 & 0.1 & 0.7 & Sec. 4.4.2.3.1, pg 4-71 \\
\hline U Subtotal & $3.95(8.7)$ & $1.00 \times 10^{-5}$ & 1 & 0.1 & 0.7 & Sec. 4.4.2.3.1, pg 4-71 \\
\hline
\end{tabular}

\subsubsection{Furnace-Initiated Glovebox Fire (Calcining Furnace)}

A fault in the calcining furnace results in an ignition source. Any combustibles (e.g., bags) left inside the glovebox can ignite, causing a glovebox fire. The fire would be self-limiting, but before burning out would cause a suspension of the radionuclide material. The glovebox (including the window) will maintain its structural integrity. However, the particulates from the fire will challenge the internal HEPA filter, and that filter will not entrain the radionuclides. The double HEPA filtration, external to the glovebox, does not fail and provides filtration prior to discharge to the stack. Fire detection and airborne radiation monitoring equipment would provide detection of this event. Fire control and emergency response procedures guide personnel actions during this event. 
The probability of a fire in the calcining furnace releasing radioactive particulates and oxides within the building and past the filtration system into the environment is $4 \times 10^{-5} / \mathrm{y}$, which is in the "extremely unlikely" range (Table 8-1).

At the time of the event, the MAR consists of loose surface contamination within the glovebox equal to $10 \%$ of the daily inventory for the calcining furnace. The fire is external to the furnace and does not involve the inventory present in the furnace. Table 8-7 shows the source term for this event and specific citations for the $\mathrm{ARF}$ and RF.

Table 8-7. Calcining furnace initiated glovebox fire source term.

\begin{tabular}{|l|c|c|c|c|c|c|}
\hline & $\begin{array}{c}\text { MAR } \\
\text { Loose Surface } \\
\text { Contamination } \\
\text { Inventory, } \\
\text { kg (lb) }\end{array}$ & $\begin{array}{c}\text { Leak Path } \\
\text { Factor } \\
\text { (LPF) }\end{array}$ & $\begin{array}{c}\text { Ramage } \\
\text { Ratio } \\
\text { (DR) }\end{array}$ & $\begin{array}{c}\text { Airborne } \\
\text { Release } \\
\text { Fraction } \\
\text { (ARF) }\end{array}$ & $\begin{array}{c}\text { Respirable } \\
\text { Fraction } \\
\text { (RF) }\end{array}$ & $\begin{array}{c}\text { DOE-HDBK-3010-94 } \\
\text { Ref. }\end{array}$ \\
\hline Pu/Am Subtotal & $0.45(1.0)$ & $1.00 \times 10^{-5}$ & 1 & $6.00 \times 10^{-3}$ & 0.01 & Sec. 4.4 .1 .1$, pg 4-57 \\
\hline U Subtotal & $0.089(0.2)$ & $1.00 \times 10^{-5}$ & 1 & $6.00 \times 10^{-3}$ & 0.01 & Sec. 4.4 .1 .1$, pg $4-57$ \\
\hline
\end{tabular}

\subsubsection{Seismic Event}

The only natural phenomenon discussed in the SRS F-Canyon SAR that results in a radiological release is the DBE, which corresponds to $0.25 \mathrm{~g}$ ground acceleration. Preliminary seismic analysis for the canyon structures and equipment has indicated that vessels will not overturn, but some line breaks may occur, resulting in a loss of primary containment. The building itself will remain intact. Therefore, the release sequence for an earthquake is the loss of radioactive material to the secondary confinement, with subsequent escape through the building filtration system resulting in airborne releases at ground level. Because the filtration system and ventilation system are assumed to be safety class, an LPF of $1 \times 10^{-5}$ was assumed.

For the SRS area, these earthquakes occur at a frequency of $2 \times 10^{-4} / \mathrm{y}$. This is in the "unlikely" range (Table 8-1).

The plutonium conversion seismic event source term must be included in the source term used to evaluate a seismic event. For plutonium conversion, at the time of the event the entire day's inventory is present in the form of an oxide powder. Table 8-8 shows the plutonium conversion contribution to the seismic event source term and specific citations for the ARF and RF. 
Table 8-8. Plutonium conversion contribution to the seismic event source term.

\begin{tabular}{|l|c|c|c|c|c|c|}
\hline & $\begin{array}{c}\text { Daily } \\
\text { Inventory, } \\
\text { kg (lb) }\end{array}$ & $\begin{array}{c}\text { Leak Path } \\
\text { Factor } \\
\text { (LPF) }\end{array}$ & $\begin{array}{c}\text { Damage } \\
\text { Ratio } \\
\text { (DR) }\end{array}$ & $\begin{array}{c}\text { Airborne } \\
\text { Release } \\
\text { Fraction } \\
\text { (ARF) }\end{array}$ & $\begin{array}{c}\text { Respirable } \\
\text { Fraction } \\
\text { (RF) }\end{array}$ & $\begin{array}{c}\text { DOE-HDBK-3010-94 } \\
\text { Ref. }\end{array}$ \\
\hline Pu/Am Subtotal & $25(55)$ & $1.00 \times 10^{-5}$ & 1 & $2.00 \times 10^{-3}$ & 0.3 & Sec. 4.4.3.1.3, pg 4-82 \\
\hline U Subtotal & $8.30(18.3)$ & $1.00 \times 10^{-5}$ & 1 & $2.00 \times 10^{-3}$ & 0.3 & Sec. 4.4.3.1.3, pg 4-82 \\
\hline
\end{tabular}

\subsubsection{Vault Criticality}

A natural phenomena hazard (NPH) induced criticality occurs during a seismic event in the in-process storage vault. The storage racks in the in-process storage vault would be designed to maintain a subcritical configuration even in the event of a DBE. However, this event is evaluated based on the assumption that the storage racks and the containers holding the fissile material fail and fissile material forms a critical geometry below the storage rack debris during a DBE. A criticality of this nature is anticipated to result in $1 \times 10^{19}$ fissions (Table 8-2).

The frequency for this event is $5 \times 10^{-7} / \mathrm{y}$. This is in the "beyond extremely unlikely" range (Table 8-1).

The fission yield source term was based on the criticality source term reported in SRS F-Canyon Safety Analysis. For conservatism, $1 \times 10^{19}$ fissions were assumed versus the $2 \times 10^{18}$ fissions reported in SRS F-Canyon Safety Analysis. The ARF, RF, and DR were obtained from SRS F-Canyon Safety Analysis, which states that "due to the size of individual particles in a powder, the fraction of volatile fission products (noble gases, iodine, ruthenium) present are so close to the surface that they are released ...." Therefore, the DR would be 1.0. Table 8-2 reflects the source term associated with the noble gases and volatile radioisotopes for this event. For conservatism and due to the energy associated with $1 \times 10^{19}$ fissions, non-volatile radioisotopes will be released with the same RFs as the volatile nuclides. Table 8-9 reflects the source term for the non-volatile radioisotopes in this event.

\subsubsection{Hydrogen Explosion in Plutonium Conversion Room}

A hydrogen explosion event may occur in the room due to supply pipe leak. Conversion of plutonium metal is accomplished using the HYDOX process. Hydrogen gas is introduced as a part of the HYDOX process. If the hydrogen supply piping leaks into the operating/maintenance room, the hydrogen gas may be ignited by an electrical short or the use of mechanical equipment, causing a hydrogen explosion. Depending on the volume of the leak, the structural integrity the glovebox glove ports may fail and disperse the plutonium oxide. The building 
Table 8-9. Vault criticality non-volatile source term.

\begin{tabular}{|l|c|c|c|c|c|c|}
\hline Radionuclide & $\begin{array}{c}\text { MAR } \\
\text { Inventory, } \\
\text { kg (lb) }\end{array}$ & $\begin{array}{c}\text { Leak } \\
\text { Path } \\
\text { Factor } \\
\text { (LPF) }\end{array}$ & $\begin{array}{c}\text { Damage } \\
\text { Ratio } \\
\text { (DR) }\end{array}$ & $\begin{array}{c}\text { Airborne } \\
\text { Release } \\
\text { Fraction } \\
\text { (ARF) }\end{array}$ & $\begin{array}{c}\text { Respirable } \\
\text { Fraction } \\
\text { (RF) }\end{array}$ & $\begin{array}{c}\text { DOE-HDBK-3010- } \\
\text { 94 Ref. }\end{array}$ \\
\hline Pu239 & & $1.00 \times 10^{-5}$ & 1 & $4 \times 10^{-4}$ & 1 & Sec. 6.3.2, pg 6-23 \\
\hline Pu240 & & $1.00 \times 10^{-5}$ & 1 & $4 \times 10^{-4}$ & 1 & Sec. 6.3.2, pg 6-23 \\
\hline Pu241 & & $1.00 \times 10^{-5}$ & 1 & $4 \times 10^{-4}$ & 1 & Sec. 6.3.2, pg 6-23 \\
\hline Pu242 & & $1.00 \times 10^{-5}$ & 1 & $4 \times 10^{-4}$ & 1 & Sec. 6.3.2, pg 6-23 \\
\hline Am241 & & $1.00 \times 10^{-5}$ & 1 & $6 \times 10^{-4}$ & 1 & Sec. 6.3.2, pg 6-23 \\
\hline Pu/Am Subtotal & $1,250(2,753)$ & & & & & \\
\hline U235 & & $1.00 \times 10^{-5}$ & 1 & $4 \times 10^{-4}$ & 1 & Sec. 6.3.2, pg 6-23 \\
\hline U238 & & $1.00 \times 10^{-5}$ & 1 & $4 \times 10^{-4}$ & 1 & Sec. 6.3.2, pg 6-23 \\
\hline U Subtotal & $415(914)$ & & & & & \\
\hline
\end{tabular}

ventilation and double HEPA filtration does not fail and provides filtration prior to discharge to the stack. Engineered safety features and administrative controls mitigate the consequences of this event. Alarm response procedures and emergency response procedures guide personnel actions during this event.

Four scenarios are considered: Scenario 1A, in which the explosion is attributed to an inadvertent introduction of oxygen or some other gas that reacts adversely with the hydrogen in the furnace; Scenario $1 \mathrm{~B}$, in which the explosion is attributed to a leak of ambient air into the system; Scenario $2 \mathrm{~A}$, in which the explosion is attributed to the contents in the furnace; and Scenario 2B, in which the explosion is attributed to the amount of materials in the furnace.

The frequency for Scenario 1A that particulates and radioactive nuclides will be released within the building is $1.3 \times 10^{-5} / \mathrm{y}$, which is in the "extremely unlikely" range (Table 8-1). The frequency for Scenario 1B is much lower.

The probability of an explosion in the HYDOX furnace releasing radioactive particulates and radionuclides within the building is $5 \times 10^{-4} / \mathrm{y}$, which is in the "unlikely" range.

In Scenario 2B, the explosion is attributed to the amount of material in the furnace. There are 200 batches per year (once per day) when an explosion could occur. The operator preparing the material to go into the furnace would have to fail to obtain the correct amount of materials and a second operator actively participating in checking this process fail to catch the error. There must be enough material present to be capable of a sufficiently adverse effect, i.e., explosion. The assumptions and analysis for Scenario 2B parallel Scenario 2A such that the same frequency of $5 \times 10^{-4} / \mathrm{y}$ is obtained again. 
The sum of the frequencies for all four scenarios $(1 \mathrm{~A}, 1 \mathrm{~B}, 2 \mathrm{~A}$, and $2 \mathrm{~B})$ that particulates and radionuclides will be released within the building is $1 \times 10^{-3} / \mathrm{y}$, which remains in the "unlikely" range.

At the time of the event, the entire day's inventory for all the plutonium conversion gloveboxes is present in the form of an oxide powder. Table 8-10 shows the source term for this event and specific citations for the ARF and RF.

Table 8-10. Explosion in the plutonium conversion segment source term.

\begin{tabular}{|l|c|c|c|c|c|c|}
\hline & $\begin{array}{c}\text { MAR } \\
\text { Daily } \\
\text { Inventory, } \\
\text { kg (lb) }\end{array}$ & $\begin{array}{c}\text { Leak Path } \\
\text { Factor } \\
\text { (LPF) }\end{array}$ & $\begin{array}{c}\text { Damage } \\
\text { Ratio } \\
\text { (DR) }\end{array}$ & $\begin{array}{c}\text { Airborne } \\
\text { Release } \\
\text { Fraction } \\
\text { (ARF) }\end{array}$ & $\begin{array}{c}\text { Respirable } \\
\text { Fraction } \\
\text { (RF) }\end{array}$ & $\begin{array}{c}\text { DOE-HDBK-3010-94 } \\
\text { Ref. }\end{array}$ \\
\hline Pu/Am Subtotal & $25(55)$ & $1.00 \times 10^{-5}$ & 1 & $5.00 \times 10^{-3}$ & 0.3 & Sec. 4.4.2.2.2, pg 4-67 \\
\hline U Subtotal & $8.3(18.3)$ & $1.00 \times 10^{-5}$ & 1 & $5.00 \times 10^{-3}$ & 0.3 & Sec. 4.4.2.2.2,pg 4-67 \\
\hline
\end{tabular}

\subsection{First-Stage Immobilization Glass Accident Sequences}

\subsubsection{Criticality in Rotary Splitter Tumbler}

Design limits on rotary splitter tumbler volume would serve to prevent an inadvertent criticality. Therefore, a criticality accident (Table 8-2) could result from human error associated with improper isotopic blending techniques that would exceed criticality safety limit administrative controls. These errors include dispersion errors, in which one of the receipt cans is charged with more than one charge of a particular oxide feed or an equipment (hopper rotation) miscalibration error causes a multiple batch of oxide feed to go to one particular receipt can. The batching operation would be a procedure-guided operator action. "Double contingency" principles would require independent controls or independent verification of administrative controls to ensure the blending processing steps. In the event a criticality occurred, the blending glovebox structure would remain intact and confine fission products and limit worker exposure to direct radiation. The criticality alarm system and facility evacuation procedures are important mitigating features.

The primary operator performing the isotopic blending operations could be assumed to make an error if procedures are not followed.

The probability of having a criticality accident and releasing radioactive nuclides past the filtration system and into the environment is $3 \times 10^{-5} / \mathrm{y}$, which is in the "extremely unlikely" range (Table 8-1). 
The fission yield source term was based on the criticality source term reported in the SRS F-Canyon Safety Analysis. For conservatism, $1 \times 10^{19}$ fissions were assumed versus the $2 \times 10^{18}$ fissions reported in The SRS F-Canyon Safety Analysis. The ARF, RF, and DR were obtained from DOE-HDBK-3010-94, which states that "Due to the size of individual particles in a powder, it is assumed that the fraction of volatile fission products (noble gases, iodine, ruthenium) present are so close to the surface that they are released ...." Therefore, the DR would be 1.0. Table 8-2 reflects the source term associated with the noble gases and volatile radioisotopes for this event. For conservatism and due to the energy associated with $1 \times 10^{19}$ fissions, it is assumed that non-volatile radioisotopes will be released with the same RFs as the volatile nuclides. Table 8-11 reflects the source term for the non-volatile radioisotopes in this event.

Table 8-11. Rotary splitter tumbler criticality non-volatile source term.

\begin{tabular}{|l|c|c|c|c|c|c|}
\hline Radionuclide & $\begin{array}{c}\text { MAR } \\
\text { Inventory, } \\
\text { kg (lb) }\end{array}$ & $\begin{array}{c}\text { Leak Path } \\
\text { Factor (LPF) }\end{array}$ & $\begin{array}{c}\text { Damage } \\
\text { Ratio } \\
\text { (DR) }\end{array}$ & $\begin{array}{c}\text { Airborne } \\
\text { Release } \\
\text { Fraction } \\
\text { (ARF) }\end{array}$ & $\begin{array}{c}\text { Respirable } \\
\text { Fraction } \\
\text { (RF) }\end{array}$ & $\begin{array}{c}\text { DOE-HDBK-3010-94 } \\
\text { Ref. }\end{array}$ \\
\hline Pu239 & & $1.00 \times 10^{-5}$ & 1 & $4 \times 10^{-4}$ & 1 & Sec. 6.3.2, pg 6-23 \\
\hline Pu240 & & $1.00 \times 10^{-5}$ & 1 & $4 \times 10^{-4}$ & 1 & Sec. 6.3.2, pg 6-23 \\
\hline Pu241 & & $1.00 \times 10^{-5}$ & 1 & $4 \times 10^{-4}$ & 1 & Sec. 6.3.2, pg 6-23 \\
\hline Pu242 & & $1.00 \times 10^{-5}$ & 1 & $4 \times 10^{-4}$ & 1 & Sec. 6.3.2, pg 6-23 \\
\hline Am241 & & $1.00 \times 10^{-5}$ & 1 & $6 \times 10^{-4}$ & 1 & Sec. 6.3.2, pg 6-23 \\
\hline PuAm Subtotal & $4.17(9.18)$ & & & & & \\
\hline U235 & & $1.00 \times 10^{-5}$ & 1 & $4 \times 10^{-4}$ & 1 & Sec. 6.3.2, pg 6-23 \\
\hline U238 & & $1.00 \times 10^{-5}$ & 1 & $4 \times 10^{-4}$ & 1 & Sec. 6.3.2, pg 6-23 \\
\hline U Subtotal & $1.38(3.04)$ & & & & & \\
\hline
\end{tabular}

\subsubsection{Melter Eruption}

The melter eruption postulated event results from a buildup or addition of impurities to the glass frit or melt. Impurities range from water, which may cause a steam eruption, to chemical contaminants, which can react at elevated temperatures and produce a highly exothermic reaction (eruption or deflagration). The resulting sudden pressure increase is assumed to eject the fissile material bearing melt liquid into the processing glovebox structure. The energy release is less than that which would challenge the glovebox structure. The melter off-gas system removes or dilutes explosive mixtures that may buildup in the gas space above the molten material. Melter operating procedures and verifications act to prevent the addition of impure or erroneous materials to the melter. In the event an eruption does occur, the appearance and sound of a large eruption would alert operating personnel. A 
small eruption might be detected only by airborne radiation monitors because the melters would be located inside a glovebox in a heavily shielded area and be remotely or robotically operated. Effects of the eruption would be mitigated by the design of the melter, which would include methods of venting to respond to an over-pressurization event. The melter glovebox structure, filter, and ventilation system would limit radioactive material released in the eruption. The heat from the eruption may burn or melt the glovebox glove and the glove rupture may provide a pathway for the radionuclides through the gloveport into the building ventilation system. But again, the ventilation system would limit radioactive material released to the environment to $0.001 \%$ of all dispersed particulates. Engineered safety features and administrative controls mitigate the consequences of this event. Alarm response procedures and emergency response procedures guide personnel actions during this event.

The probability of having an eruption and releasing material to the environment is $2.5 \times 10^{-3} / \mathrm{y}$. This is in the "unlikely" range (Table 8-1).

The inventory is that of one batch in one melter. The entire contents of the melter are ejected into the glovebox. Table 8-12 shows the source term for this event and specific citations for the ARF and RF.

Table 8-12. Melter eruption source term.

\begin{tabular}{|l|c|c|c|c|c|c|}
\hline & $\begin{array}{c}\text { MAR } \\
\text { Inventory, } \\
\text { kg (lb) }\end{array}$ & $\begin{array}{c}\text { Leak Path } \\
\text { Factor } \\
\text { (LPF) }\end{array}$ & $\begin{array}{c}\text { Damage } \\
\text { Ratio } \\
\text { (DR) }\end{array}$ & $\begin{array}{c}\text { Airborne } \\
\text { Release } \\
\text { Fraction } \\
\text { (ARF) }\end{array}$ & $\begin{array}{c}\text { Respirable } \\
\text { Fraction } \\
\text { (RF) }\end{array}$ & $\begin{array}{c}\text { DOE-HDBK-3010-94 } \\
\text { Ref. }\end{array}$ \\
\hline Pu/Am Subtotal & $1.39(3.06)$ & $1.00 \times 10^{-5}$ & 1 & $1.00 \times 10^{-4}$ & 1 & Sec. 3.2.2.3.1, pg 3-20 \\
\hline U Subtotal & $0.46(1.01)$ & $1.00 \times 10^{-5}$ & 1 & $1.00 \times 10^{-4}$ & 1 & Sec. 3.2.2.3.1, pg 3-20 \\
\hline
\end{tabular}

\subsubsection{Melter Spill}

The melter spill event addresses a release of molten glass to the process glovebox space due to improper alignment of the product glass cans during pouring operations. The product glass can and melter pouring spout will be specifically designed to facilitate proper alignment. Interlocks will be provided that require the product glass can to be properly positioned before pouring commences. If the interlock fails, the canister could be mispositioned and the molten glass would spill into the process glovebox structure. Impurities in the molten material might clog the pouring spout and divert the flowing material. Operating procedures and verifications act to prevent the addition of impure or wrong materials to the melter feed. Can level or volume indicators, airborne radiation monitors, and associated alarm response procedures guide mitigating actions. The melter glovebox enclosure 
and the off-gas exhaust ventilation system would confine radioactive material released in the spill. The glovebox structure and its associated filtered exhaust ventilation system are not impacted by this event.

The probability of having a melter spill and releasing radioactive material to the environment is $3 \times 10^{-4} / \mathrm{y}$, which is in the "unlikely" range (Table 8-1).

The inventory is that of one batch in one melter. The entire contents of the melter are spilled into the glovebox. Table 8-13 shows the source term for this event and specific citations for the ARF and RF.

Table 8-13. Melter spill source term.

\begin{tabular}{|c|c|c|c|c|c|c|c|c|}
\hline & $\begin{array}{c}\text { MAR } \\
\text { Inventory, } \\
\text { kg (lb) }\end{array}$ & $\begin{array}{l}\text { Leak } \\
\text { Path } \\
\text { Factor } \\
(\text { LPF) }\end{array}$ & $\begin{array}{c}\text { Damage } \\
\text { Ratio } \\
\text { (DR) }\end{array}$ & $\begin{array}{c}\begin{array}{c}\text { A-empirical } \\
\text { correlation, } \\
\mathrm{cm}^{3}\end{array} \\
\frac{\mathrm{g}-\mathrm{cm}^{2} / \mathrm{s}^{2}}{\left(\frac{\mathrm{in}^{3}}{\mathrm{lb}-\mathrm{in}^{2} / \mathrm{s}^{2}}\right)}\end{array}$ & $\begin{array}{c}\text { P- } \\
\text { density } \\
\text { g/cm }{ }^{3} \\
\left(\mathrm{lb} / \mathrm{in}^{3}\right)\end{array}$ & $\begin{array}{l}\text { g-grav } \\
\text { accel } \\
\mathrm{cm} / \mathrm{s}^{2} \\
\left(\mathrm{ft} / \mathrm{s}^{2}\right)\end{array}$ & $\begin{array}{c}\text { h- } \\
\text { height } \\
\text { of fall } \\
\mathrm{cm} \text { (in) }\end{array}$ & $\begin{array}{c}\mathbf{A R F} \times \\
\mathbf{R F}\end{array}$ \\
\hline $\begin{array}{l}\text { Pu/Am } \\
\text { Subtotal }\end{array}$ & $1.39(3.06)$ & $1.00 \times 10^{-5}$ & 1 & $\begin{array}{l}2.00 \times 10^{-11} \\
\left(3.6 \times 10^{-9}\right)\end{array}$ & $\begin{array}{c}4 \\
(0.15)\end{array}$ & $\begin{array}{l}980 \\
(32)\end{array}$ & $\begin{array}{c}300 \\
(118)\end{array}$ & $2.35 \times 10^{-5}$ \\
\hline U Subtotal & $0.46(1.01)$ & $1.00 \times 10^{-5}$ & 1 & $\begin{array}{l}2.00 \times 10^{-11} \\
\left(3.6 \times 10^{-9}\right)\end{array}$ & $\begin{array}{c}4 \\
(0.15)\end{array}$ & $\begin{array}{l}980 \\
(32)\end{array}$ & $\begin{array}{c}300 \\
(118)\end{array}$ & $2.35 \times 10^{-5}$ \\
\hline
\end{tabular}

Note: DOE-HDBK-3010-94 page reference: Sec. 4.3.1.1, page 4-47; Sec. 4.3.3, page 4-52.

\subsubsection{Seismic Event}

The only natural phenomenon discussed in the SRS F-Canyon SAR that results in a radiological release is the DBE, which corresponds to $0.25 \mathrm{~g}$ ground acceleration. The facility will have seismically qualified systems, structures, and components. Additionally, the facility filtration system is safety class and will operate during and after a DBE. However, for the purposes of this analysis, a loss of primary containment occurs. The building itself will remain intact. Therefore, the release sequence for an earthquake is the loss of radioactive material to the secondary confinement, with subsequent escape through the building filtration system. Because the filtration system and ventilation system are safety class, an LPF of $1.0 \times$ $10^{-5}$ was used.

For the SRS area, these earthquakes occur at a frequency of $2 \times 10^{-4} / \mathrm{y}$, which is in the "unlikely" range (Table 8-1).

The plutonium conversion seismic event source term (Section 8.4.6) must be included when evaluating this seismic event. The NPH induced criticality event in the in-process storage vault (Section 8.4.7) was not considered as part of this event due to the event frequency being "beyond extremely unlikely." 
At the time of the event, the following inventory assumptions are made regarding the glass immobilization process:

- The inventory for the rotary splitter tumbler is one output can in the form of oxide powder.

- The inventory for oxide grinding is one can in one grinder in the form of a slurry.

- The inventory for blend melter feed is one can in each of two blenders in the form of a slurry.

- The inventory for feed storage is 18 cans in the form of oxide powder.

- The inventory for the melter is one batch in each of six melters.

The inventory for the vitrified material was not considered. Studies supporting the DWPF SAR indicate that the source term resulting from the dropping or tipping of a vitrified waste $\log$, without credit for the steel canister, would be negligible. Consequently, a seismic event not would release radioactive material from the cans of vitrified plutonium.

No credit was taken for the primary containment boundaries of the various process components. Table 8-14(a) shows the source terms for each of the process components in this event (except for meter spill, which is shown separately in Table 8.14(b)) and the specific citations for the ARFs and RFs.

Table 8-14(a). Glass immobilization process component seismic event source terms.

\begin{tabular}{|l|c|c|c|c|c|c|}
\hline & $\begin{array}{c}\text { MAR } \\
\text { Inventory, } \\
\text { kg (lb) }\end{array}$ & $\begin{array}{c}\text { Leak Path } \\
\text { Factor } \\
\text { (LPF) }\end{array}$ & $\begin{array}{c}\text { Damage } \\
\text { Ratio } \\
\text { (DR) }\end{array}$ & $\begin{array}{c}\text { Airborne } \\
\text { Release } \\
\text { Fraction } \\
\text { (ARF) }\end{array}$ & $\begin{array}{c}\text { Respirable } \\
\text { Fraction } \\
\text { (RF) }\end{array}$ & $\begin{array}{c}\text { DOE-HDBK-3010-94 } \\
\text { Ref. }\end{array}$ \\
\hline Rotary Splitter \\
\hline Pu/Am Subtotal & $4.17(9.18)$ & $1.00 \times 10^{-5}$ & 1 & $2.00 \times 10^{-3}$ & 0.3 & Sec. 4.4.3.1.3, pg 4-82 \\
\hline U Subtotal & $1.38(3.04)$ & $1.00 \times 10^{-5}$ & 1 & $2.00 \times 10^{-3}$ & 0.3 & Sec. 4.4.3.1.3, pg 4-82 \\
\hline Oxide Grinding & \multicolumn{7}{|l|}{} \\
\hline Pu/Am Subtotal & $4.17(9.18)$ & $1.00 \times 10^{-5}$ & 1 & $5.00 \times 10^{-5}$ & 0.8 & Sec. 4.4.3.3.1, pg 4-85 \\
\hline U Subtotal & $1.38(3.04)$ & $1.00 \times 10^{-5}$ & 1 & $5.00 \times 10^{-5}$ & 0.8 & Sec. 4.4.3.3.1, pg 4-85 \\
\hline Blend Melter Feed \\
\hline Pu/Am Subtotal & $2.78(6.12)$ & $1.00 \times 10^{-5}$ & 1 & $5.00 \times 10^{-5}$ & 0.8 & Sec. 4.4.3.3.1, pg 4-85 \\
\hline U Subtotals & $0.92(2.03)$ & $1.00 \times 10^{-5}$ & 1 & $5.00 \times 10^{-5}$ & 0.8 & Sec. 4.4.3.3.1, pg 4-85 \\
\hline Feed Storage & $25(55)$ & $1.00 \times 10^{-5}$ & 1 & $2.00 \times 10^{-3}$ & 0.3 & Sec. 4.4.3.1.3, pg 4-82 \\
\hline Pu/Am Subtotal & $8.3(18.3)$ & $1.00 \times 10^{-5}$ & 1 & $2.00 \times 10^{-3}$ & 0.3 & Sec. 4.4.3.1.3, pg 4-82 \\
\hline U Subtotal
\end{tabular}


Table 8-14(b). Glass immobilization process component seismic event source terms, melter spill.

\begin{tabular}{|c|c|c|c|c|c|c|c|c|}
\hline & $\begin{array}{c}\text { MAR } \\
\text { Inventory, } \\
\text { kg (lb) }\end{array}$ & $\begin{array}{c}\text { Leak } \\
\text { Path Factor } \\
\text { (LPF) }\end{array}$ & $\begin{array}{c}\text { Damage } \\
\text { Ratio } \\
\text { (DR) }\end{array}$ & $\begin{array}{c}\begin{array}{c}\text { A-empirical } \\
\text { correlation, }\end{array} \\
\frac{\mathrm{cm}^{3}}{\mathrm{~g}-\mathrm{cm}^{2} / \mathrm{s}^{2}} \\
\left(\frac{\mathrm{in}^{3}}{\mathrm{lb}-\mathrm{in}^{2} / \mathrm{s}^{2}}\right)\end{array}$ & $\begin{array}{l}\text { P-den- } \\
\text { sity, } \\
\text { g/cm } \\
\left(\mathrm{lb} / \mathrm{in}^{3}\right)\end{array}$ & $\begin{array}{l}\text { g-grav } \\
\text { accel, } \\
\mathrm{cm} / \mathrm{s}^{2} \\
\left(\mathrm{ft} / \mathrm{s}^{2}\right)\end{array}$ & $\begin{array}{c}\text { h- } \\
\text { height } \\
\text { of fall, } \\
\mathrm{cm} \text { (in) }\end{array}$ & $\begin{array}{c}\text { ARF } \times \\
\text { RF }\end{array}$ \\
\hline \multicolumn{9}{|c|}{ Melter Spill } \\
\hline $\begin{array}{l}\text { Pu /Am } \\
\text { Subtotal }\end{array}$ & $8.34(18.35)$ & $1.00 \times 10^{-5}$ & 1 & $\begin{array}{l}2.00 \times 10^{-11} \\
\left(3.6 \times 10^{-9}\right)\end{array}$ & $\begin{array}{c}4 \\
(0.15)\end{array}$ & $\begin{array}{l}980 \\
(32)\end{array}$ & $\begin{array}{c}300 \\
(118)\end{array}$ & $2.35 \times 10^{-5}$ \\
\hline $\begin{array}{l}\text { Subtotal } \\
\text { Sula }\end{array}$ & $2.76(6.07)$ & $1.00 \times 10^{-5}$ & 1 & $\begin{array}{l}2.00 \times 10^{-11} \\
\left(3.6 \times 10^{-9}\right)\end{array}$ & $\begin{array}{c}4 \\
(0.15)\end{array}$ & $\begin{array}{l}980 \\
(32)\end{array}$ & $\begin{array}{c}300 \\
(118)\end{array}$ & $2.35 \times 10^{-5}$ \\
\hline
\end{tabular}

Note: DOE-HDBK-3010-94 page reference: Sec. 4.3.1.1, page 4-47; Sec 4.3.3, page 4-52.

\subsection{Second-Stage Immobilization - Canister Loading, Transport, and HLW Glass Pour Accident Sequences}

\subsubsection{Can Handling Accident (prior to shipment to DWPF)}

A can handling accident would involve events with a can containing a plutonium glass log. Studies supporting the DWPF SAR indicate that the source term resulting from the dropping or tipping of a log of vitrified waste, without credit for the steel canister, would be negligible. The glass immobilization technology results in a form with a durability that is comparable to the DWPF vitrified waste form. Consequently, no postulated can handling event would result in a radioactive release to the environment.

\subsubsection{Transportation Accident (en route from PIP to DWPF)}

After the plutonium is immobilized and the cans placed into a lattice framework inside a waste canister, they will be transported to the DWPF. This will require a total of 250 trips between the PIP and the DWPF facility. The distance from the PIP to the DWPF would be approximately 3.9 miles. Based on National Highway Traffic Safety Administration (NHTSA) accident rate data for large trucks, this would result in a total of $2.63 \times 10^{-5}$ traffic related fatalities at SRS. The accident rate data used to calculate the number of fatalities was based on large trucks traveling over public roadways. Transportation of the immobilized plutonium would not be on public roadways, but on limited access roadways on a DOE facility. Furthermore, access to the roadways during the transportation of the immobilized plutonium will be limited to only those vehicles directly involved in the transfer of the immobilized 
plutonium. Consequently, the actual number of traffic fatalities from the 250 trips would be significantly less than the calculated value.

Studies supporting the DWPF SAR indicate that the source term resulting from dropping or tipping a log of vitrified waste, without credit for the steel canister, would be negligible. The glass immobilization technology results in a form with a durability that is comparable to the DWPF vitrified waste form. Therefore, the calculated fatalities would be solely a result of traffic accidents and not involve a release of radioactive materials. This is because no postulated transportation accident would result in a radioactive release to the environment.

\subsubsection{Melter Spill (melt pour at DWPF)}

A spill of melt material at DWPF has previously been assessed in the DWPF EIS and the DWPF SAR. The incremental impact due to the plutonium-glass present in a DWPF canister would be negligible due to the durability of HLW glass. This is because the DWPF SAR indicates that the source term resulting from dropping or tipping a log of vitrified waste, without credit for the steel canister, would be negligible. The glass immobilization technology results in a form with a durability that is comparable to the DWPF vitrified waste form. Consequently, no postulated DWPF melter event would result in a release of immobilized plutonium to the environment.

\subsubsection{Canister Handling Accident (after melt pour at DWPF)}

Events involving the handling and storage of DWPF canisters were previously assessed in the DWPF EIS and the DWPF SAR. The incremental impact due to the plutonium-glass present in a DWPF canister would be negligible due to the durability of the HLW glass. This is because the DWPF SAR indicates that the source term resulting from the dropping or tipping of a log of vitrified waste, without credit for the steel canister, would be negligible. The glass immobilization technology results in a form with a durability that is comparable to the DWPF vitrified waste form. Consequently, no postulated DWPF canister event would result in a release of immobilized plutonium to the environment.

\subsection{Beyond Design Basis Seismic Event}

The event with the greatest potential for facility damage and off-site impact is a beyond design basis seismic event, or beyond extremely unlikely (BEU) event, which results in a complete building collapse. Overturning of vessels and rupture will occur due to falling debris, resulting in a loss of primary containment. Because the building is assumed to collapse, the release sequence for this event is the loss of radioactive material directly to the environment, resulting in airborne releases at 
ground level. Rather than the filter LPF of $1.0 \times 10^{-5}$, an LPF of 1.0 was assumed for this event.

For the SRS area, these earthquakes occur at a frequency of $1.2 \times 10^{-4} / \mathrm{y}$. This is in the "unlikely" range (Table 8-1).

At the time of the event, the following inventory assumptions are made:

- The inventory for plutonium conversion is the entire day's inventory in the form of oxide powder

- The inventory for the rotary splitter tumbler is one output can in the form of oxide powder

- The inventory for oxide grinding is one can in one grinder in the form of a slurry

- The inventory for blend melter feed is one can in each of two blenders in the form of a slurry

- The inventory for feed storage is 18 cans in the form of oxide powder

- The inventory for the melter is one batch in each of the six melters.

The inventory for the vitrified material was not considered. Studies supporting the DWPF SAR indicate that the source term resulting from the dropping or tipping of a vitrified waste log, without credit for the steel canister, would be negligible. Consequently, a seismic event would not release radioactive material from the cans of vitrified plutonium.

No credit was taken for the primary containment boundaries of the various process components. Tables 8-15 through 8-16(b) show the source terms for each of the process components in this event and the specific citations for the ARF and RF.

Table 8-15. Plutonium conversion contribution to the BEU event source term.

\begin{tabular}{|l|c|c|c|c|c|c|}
\hline & $\begin{array}{c}\text { MAR } \\
\text { Daily } \\
\text { Inventory, } \\
\text { kg (lb) }\end{array}$ & $\begin{array}{c}\text { Leak } \\
\text { Path } \\
\text { Factor } \\
\text { (LPF) }\end{array}$ & $\begin{array}{c}\text { Damage } \\
\text { Ratio } \\
\text { (DR) }\end{array}$ & $\begin{array}{c}\text { Airborne } \\
\text { Release } \\
\text { Factor } \\
\text { (ARF) }\end{array}$ & $\begin{array}{c}\text { Respirable } \\
\text { Fraction } \\
\text { (RF) }\end{array}$ & $\begin{array}{c}\text { DOE-HDBK-3010-94 } \\
\text { Ref. }\end{array}$ \\
\hline $\mathrm{Pu}$ /Am Total & $25(55)$ & 1 & 1 & $1.0 \times 10^{-3}$ & 0.3 & Sec. 4.4.3.3.2, pg. 4-85 \\
\hline U Subtotal & $8.3(18.3)$ & 1 & 1 & $1.0 \times 10^{-3}$ & 0.3 & Sec. 4.4.3.3.2, pg. 4-85 \\
\hline
\end{tabular}


Table 8-16(a). Glass immobilization process component BEU seismic event source terms.

\begin{tabular}{|c|c|c|c|c|c|c|}
\hline & $\begin{array}{c}\text { Inventory, } \\
\text { kg (lb) }\end{array}$ & $\begin{array}{l}\text { Leak } \\
\text { Path } \\
\text { Factor } \\
\text { (LPF) }\end{array}$ & $\begin{array}{c}\text { Damage } \\
\text { Ratio } \\
\text { (DR) }\end{array}$ & $\begin{array}{c}\text { Airborne } \\
\text { Release } \\
\text { Fraction } \\
\text { (ARF) }\end{array}$ & $\begin{array}{c}\text { Respirable } \\
\text { Fraction } \\
\text { (RF) }\end{array}$ & $\begin{array}{l}\text { DOE-HDBK-3010-94 } \\
\text { Ref. }\end{array}$ \\
\hline \multicolumn{7}{|l|}{ Rotary Splitter } \\
\hline $\mathrm{Pu} /$ Am Subtotal & $4.17(9.18)$ & 1 & 1 & $1.00 \times 10^{-3}$ & 0.3 & Sec. 4.4.3.3.2, pg 4-85 \\
\hline U Subtotal & $1.38(3.04)$ & 1 & 1 & $1.00 \times 10^{-3}$ & 0.3 & Sec. 4.4.3.3.2, pg 4-85 \\
\hline \multicolumn{7}{|l|}{ Oxide Grinding } \\
\hline $\mathrm{Pu} /$ Am Subtotal & $4.17(9.18)$ & 1 & 1 & $5.00 \times 10^{-5}$ & 0.8 & Sec. 3.2.3.2, pg 3-35 \\
\hline U Subtotal & $1.38(3.04)$ & 1 & 1 & $5.00 \times 10^{-5}$ & 0.8 & Sec. 3.2.3.2, pg 3-35 \\
\hline \multicolumn{7}{|c|}{ Blend Melter Feed } \\
\hline $\mathrm{Pu} /$ Am Subtotal & $2.78(6.12)$ & 1 & 1 & $5.00 \times 10^{-5}$ & 0.8 & Sec. 3.2.3.2, pg 3-35 \\
\hline U Subtotal & $0.92(2.02)$ & 1 & 1 & $5.00 \times 10^{-5}$ & 0.8 & Sec. 3.2.3.2, pg 3-35 \\
\hline \multicolumn{7}{|l|}{ Feed Storage } \\
\hline $\mathrm{Pu} /$ Am Subtotal & $25(55)$ & 1 & 1 & $1.00 \times 10^{-3}$ & 0.3 & Sec. 4.4.3.3.2, pg 4-85 \\
\hline U Subtotal & $8.3(18.3)$ & 1 & 1 & $1.00 \times 10^{-3}$ & 0.3 & Sec. 4.4.3.3.2, pg 4-85 \\
\hline
\end{tabular}

Table 8-16(b). Glass immobilization process component BEU event source terms, melter spill.

\begin{tabular}{|c|c|c|c|c|c|c|c|c|}
\hline & $\begin{array}{c}\text { Inventory, } \\
(\mathrm{kg})\end{array}$ & $\begin{array}{l}\text { Leak Path } \\
\text { Factor } \\
\text { (LPF) }\end{array}$ & $\begin{array}{c}\text { Damage } \\
\text { Ratio } \\
\text { (DR) }\end{array}$ & $\begin{array}{c}\begin{array}{c}\text { A-empirical } \\
\text { correlation, } \\
\mathrm{cm}^{3}\end{array} \\
\mathrm{~g}-\mathrm{cm}^{2} / \mathrm{s}^{2} \\
\left(\frac{\mathrm{in}^{3}}{\mathrm{lb}-\mathrm{in}^{2} / \mathrm{s}^{2}}\right)\end{array}$ & $\begin{array}{c}\text { P- } \\
\text { density, } \\
\left(\mathrm{g} / \mathrm{cm}^{3}\right)\end{array}$ & $\begin{array}{l}\text { g-grav } \\
\text { accel, } \\
\left(\mathrm{cm} / \mathrm{s}^{2}\right)\end{array}$ & $\begin{array}{c}\mathrm{h}- \\
\text { height } \\
\text { of fall, } \\
\text { (cm) }\end{array}$ & $\begin{array}{c}\mathrm{ARF} \times \\
\mathbf{R F}\end{array}$ \\
\hline \multicolumn{9}{|c|}{ Melter Spill } \\
\hline $\begin{array}{l}\text { Pu /Am } \\
\text { Subtotal }\end{array}$ & $\begin{array}{c}8.34 \\
(18.35)\end{array}$ & 1 & 1 & $2.00 \times 10^{-11}$ & $\begin{array}{c}4 \\
(0.15)\end{array}$ & $\begin{array}{l}980 \\
(32)\end{array}$ & $\begin{array}{c}300 \\
(118)\end{array}$ & $2.35 \times 10^{-5}$ \\
\hline \begin{tabular}{|l} 
U \\
Subtotal
\end{tabular} & $\begin{array}{c}2.76 \\
(6.07)\end{array}$ & 1 & 1 & $2.00 \times 10^{-11}$ & $\begin{array}{c}4 \\
(0.15) \\
\end{array}$ & $\begin{array}{l}980 \\
(32) \\
\end{array}$ & $\begin{array}{c}300 \\
(118) \\
\end{array}$ & $2.35 \times 10^{-5}$ \\
\hline
\end{tabular}

Note: DOE-HDBK-3010-94 page references: Sec. 4.3.1.1, pg 4-47, Sec 4.3.3, pg 4-52. 


\subsection{Transportation}

\subsection{General}

\subsubsection{Shipping Responsibilities}

For on- or off-site transfers, the organization originating movement (i.e., the shipper) will have the ultimate responsibility for the safe transfer of material from the time the material is offered for transportation until it is received at the final destination. Individuals performing the functions of a shipper, transporter, or receiver are responsible for compliance with applicable transportation requirements.

Responsibility for the safe packaging, handling, and shipping of hazardous materials is shared by the container manufacturers, shippers, and carriers, who can be held jointly liable for violations. Typically, a number of site organizations will be involved in the on- and off-site transfer of hazardous, nonhazardous, and special nuclear materials, including the following:

- An emergency response team to assist in on-site hazardous material transportation incidents.

- A hazardous material transportation group for the overall coordination of on- or off-site hazardous material movements.

- A waste management organization for the coordination of activities related to the shipment of hazardous wastes off-site requiring a uniform hazardous waste manifest.

- Safeguards and security and accountability groups for the coordination and approval of shipments of radioactive and controlled nuclear materials transferred on-site or shipped off-site.

- An environmental protection organization for review and approval of hazardous waste manifests and land disposal restriction notifications and/or certifications for off-site shipments and for maintaining copies of returned hazardous waste manifests.

- An immobilization facility manager for directing transfer operations, including the selection and ownership (until proper receipt at its intended destination) of appropriate packaging and for ensuring safe transportation activities from the facility.

- A radiation control group for conducting radioactive screenings. 


\subsubsection{Packaging Responsibilities}

When shipping a hazardous material, packaging approved by the Department of Transportation (DOT) will be used as listed in the Hazardous Materials Table of 49CFR172.101, Columns (8a) and (8b). These include industrial packaging; Types A and B packaging, which are approved by the DOT and listed in 49CFR173.415 and 49CFR173.416, respectively; and specification packaging. A brief description of each is offered below.

- Industrial packaging, otherwise described in the regulations as "strong, leaktight packaging," meets approved industry standards for the containment of any material.

- DOT specification packaging as listed in 49CFR178 may be purchased and/or fabricated according to the listed requirements. DOT specification packagings are approved for use in accordance with the specific requirements for the materials being shipped.

- Type A packaging is designed to retain its integrity and shielding attributes under normal conditions of transportation. The packaging must pass tests prescribed for maintaining packaging integrity. Type A packaging is used to package $\mathrm{A}_{1}$ or $\mathrm{A}_{2}$ quantities of radioactive material as limited in 49CFR173.433 and/or the Table of $A_{1}$ or $A_{2}$ Values for Radionuclides found in 49CFR173.435.

- Type B packaging is used to ship quantities of radioactive material that exceed the amount specified for $A_{1}$ or $A_{2}$ quantities in Type A packagings (noted above). Type B packaging is designed to withstand normal conditions of transportation, including hypothetical accident test conditions set forth in 10CFR71. Authorized Type B packaging is listed in 49CFR173.416.

The use of approved packaging for shipments of material in quantities or forms not previously approved requires an exemption, as described in 10CFR71, Subpart B and/or 49CFR173.3. Approval for an exemption, a new packaging design, or a change in the use of existing packaging is based upon the SAR for packaging prepared to demonstrate the safety of the packaging and its intended use.

\subsection{Construction-Related Transportation Requirements}

Transportation requirements for the construction phase of the program consist of delivery of building materials (as described earlier in Table 5-1) and equipment to the site, shipment of wastes off-site, and transportation of workers to and from the site. Shipments of building materials will be by truck or rail and will be in accordance with DOT regulations. Construction generated wastes have been described in Table 7-1. Nonhazardous construction wastes will be trucked 
approximately $11 \mathrm{~km}$ (7 miles) to the sanitary landfill for disposal. Hazardous wastes will be transported approximately $8 \mathrm{~km}$ ( 5 miles) to the Hazardous Waste Storage Facility for on-site treatment and storage. Table 9-1 summarizes annual transportation requirements.

Table 9-1. Annual transportation requirements during construction.

\begin{tabular}{|l|c|c|}
\hline & $\begin{array}{c}\text { Average number per } \\
\text { year }\end{array}$ & $\begin{array}{c}\text { Peak number per } \\
\text { year }\end{array}$ \\
\hline Building material shipments & 3,000 & 4,500 \\
\hline Construction general waste shipments & 3,000 & 4,500 \\
\hline
\end{tabular}

\subsection{Operations-Related Transportation Requirements}

\subsubsection{Intersite Transportation}

Transportation of input materials will encompass material shipments from across the DOE complex. Shipments of non-pit feed materials are summarized in Table 9-2. Feed material is assumed to arrive on-site by truck or rail. Plutonium will be in the form of plutonium oxide, metals, alloys, and unirradiated fuels.

Plutonium is expected to arrive in DOT/DOE/NRC approved $6 \mathrm{M} / 2 \mathrm{R}$-like shipping packages with a maximum of $4.5 \mathrm{~kg}(9.9 \mathrm{lbs})$ of plutonium per package. The number of packages per shipment is assumed to be 40, although the number of packages may vary depending on the amount of plutonium in a package. Provisions will exist to receive and store more than one year's supply.

Hazardous materials transported by commercial carriers will be properly classified, packaged, marked, labeled, placarded, and described on shipping papers as required by the site transportation safety manual, and applicable DOT, DOE, EPA, and NRC requirements.

The highly radioactive product canisters produced will be placed in interim storage in the GWSB until being transported to an off-site repository.

It is estimated that TRU wastes are the only waste materials that will be ultimately shipped off-site. They will be packaged and transported in accord with DOE/DOT regulations. 
Table 9-2. Process material shipments during operation.

\begin{tabular}{|c|c|c|}
\hline 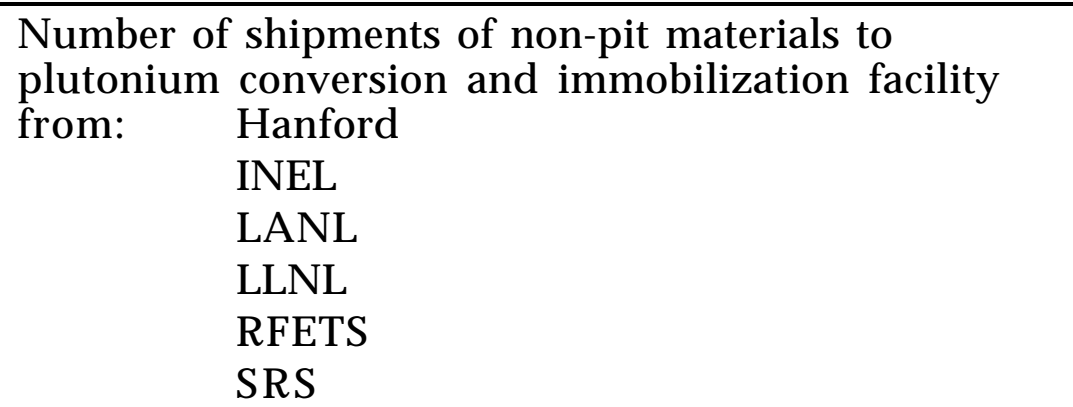 & \multicolumn{2}{|l|}{$\begin{array}{c}90-200^{1} \\
41 \\
34 \\
3 \\
90 \\
35\end{array}$} \\
\hline Container types used for shipments & \multicolumn{2}{|c|}{$\begin{array}{l}9975 \\
\text { SAF KEG } \\
6 \mathrm{M} / 2 \mathrm{R} \\
3013 \\
\text { Foodpac } \\
\text { Radial reflector cask (FFTF } \\
\text { fuel assembly) } \\
\text { Model } 60 \text { FFTF DFA pins } \\
\text { shipping container } \\
\end{array}$} \\
\hline \multicolumn{3}{|l|}{ Availability of shipping containers ${ }^{2}$} \\
\hline Average empty container weight, kg (lb) & \multicolumn{2}{|c|}{$165(364)$} \\
\hline Average bulk material weight, kg (lb) & \multicolumn{2}{|c|}{$4.4(9.7)$} \\
\hline Average isotopic content & $\begin{array}{c}\text { By Isotope } \\
{ }^{238} \mathrm{Pu} \\
{ }^{239} \mathrm{Pu} \\
{ }^{240} \mathrm{Pu} \\
{ }^{241} \mathrm{Pu} \\
{ }^{242} \mathrm{Pu} \\
{ }^{241} \mathrm{~A} \mathrm{~m} \\
\\
{ }^{235} \mathrm{U} \\
{ }^{238} \mathrm{U}\end{array}$ & $\begin{array}{c}\text { Mass \% content } \\
0.02 \\
90.96 \\
8.2 \\
0.58 \\
0.25 \\
0.94 \% \text { by weight } \\
\text { of plutonium } \\
2.0 \\
98.0\end{array}$ \\
\hline $\begin{array}{l}\text { Average exposure rate at } 2 \mathrm{~m}(6.6 \mathrm{ft}) \text { from external } \\
\text { surface of transport vehicle, } \mu \mathrm{Sv} / \mathrm{h}(\mathrm{mrem} / \mathrm{h})\end{array}$ & \multicolumn{2}{|r|}{$90(9)$} \\
\hline $\begin{array}{l}\text { Maximum anticipated dose rate at } 2 \mathrm{~m}(6.6 \mathrm{ft}) \text { from } \\
\text { external surface of transport vehicle, } \mu \mathrm{Sv} / \mathrm{h}(\mathrm{mrem} / \mathrm{h})\end{array}$ & \multicolumn{2}{|c|}{$100(10)$} \\
\hline
\end{tabular}

Notes:

1. 90 shipments for 3013 container, 200 shipments for Foodpac container.

2. Container availability: Type 9975 (for oxides) safety analysis under review for certification for oxides; secure automated fabrication (SAF KEG) type (for oxide) container safety analysis under review for certification; specification $6 \mathrm{M} / 2 \mathrm{R}$ (for metal/oxide) covers approximately 10,000 containers of various approved designs available in 30 and 55 gallon sizes; radial reflector casks to be determined (TBD); Model 60 FFTF DFA pins shipping container TBD. 


\subsubsection{Intrasite Transportation}

Although not governed by DOT hazardous materials regulations, intrasite transfers of hazardous materials must protect the health and safety of employees and prevent releases of these materials to the environment. Intrafacility transfers of hazardous materials, by commercial carrier or public vehicle, will follow site transportation safety manual guidelines. The DOE policy regarding the intrasite transportation of hazardous materials recommends that DOT requirements be fully followed but notes that individual cases may arise where DOT implementation may not be practical. In these rare cases, implementation of temporary transportation/ security provisions will be used to ensure the safety of site employees and the general public or, alternatively, the shipment must comply with off-site DOT shipping requirements. Intrabuilding movement of hazardous materials will be governed by Occupational Safety and Health Administration (OSHA) standards and addressed in applicable site documents.

SNM transfers will be accomplished by truck or rail, will be coordinated with applicable security and material control and accountability personnel, and will follow approved site procedures. The majority of SNM movements will be on "exclusive-use" (truck or rail) vehicles and the packages sealed with tamperindicating devices and/or guarded by an appropriate number of security officers necessary to protect against threats established by site policy. The immobilized SNM in canisters will be transported about $6 \mathrm{~km}$ (4 miles) to DWPF for filling with highlevel waste glass. Table 9-3 summarizes the intrasite movement of SNM.

Nonhazardous wastes will be trucked approximately $11 \mathrm{~km}$ (7 miles) to the sanitary landfill for disposal. Hazardous wastes will be transported approximately $8 \mathrm{~km}$ (5 miles) to the Hazardous Waste Storage Facility for on-site treatment and storage. LLWs will be transported $3 \mathrm{~km}$ ( 2 miles) to the TRU storage area for on-site storage above ground in low level vaults. TRU wastes will be transported $3 \mathrm{~km}$ ( 2 miles) to the TRU storage area for on-site storage above ground until shipped to WIPP. Mixed LLW will be transported two miles to the TRU storage area for aboveground on-site storage. 
Table 9-3. Intrasite transport of "canned" plutonium to the facility.

\begin{tabular}{|c|c|c|}
\hline $\begin{array}{l}\text { Number of intrasite shipments of "canned" } \\
\text { plutonium to modified HLW vitrification facility }\end{array}$ & \multicolumn{2}{|c|}{$\begin{array}{l}\text { Annual shipments } \\
\qquad 70\end{array}$} \\
\hline $\begin{array}{l}\text { Container (transport cask) types used for } \\
\text { shipments }\end{array}$ & \multicolumn{2}{|c|}{ New design } \\
\hline Availability of containers & \multicolumn{2}{|c|}{ To be designed } \\
\hline Average shipping container weight, kg (lb) & \multicolumn{2}{|r|}{ TBD } \\
\hline $\begin{array}{l}\text { Average material weight in canister, } \mathrm{kg}(\mathrm{lb}) \\
\text { Material weight in canister includes plutonium- } \\
\text { glass }(329 \mathrm{~kg}[724 \mathrm{lb}]) \text {, cans }(203 \mathrm{~kg}[447 \mathrm{lb}]) \text {, and } \\
\text { rack assembly }(50 \mathrm{~kg}[110 \mathrm{lb}])\end{array}$ & \multicolumn{2}{|c|}{$582(1,281)$} \\
\hline Weight of empty canister, kg (lb) & \multicolumn{2}{|c|}{$450(992)$} \\
\hline $\begin{array}{l}\text { Average isotopic content } \\
\qquad\left(\mathrm{U} \text { in } \mathrm{UO}_{2} \text { is } 100 \%{ }^{238} \mathrm{U}\right)\end{array}$ & $\begin{array}{c}\text { By isotope } \\
{ }^{238} \mathrm{Pu} \\
{ }^{239} \mathrm{Pu} \\
{ }^{240} \mathrm{Pu} \\
{ }^{241} \mathrm{Pu} \\
{ }^{242} \mathrm{Pu} \\
{ }^{241} \mathrm{~A} \mathrm{~m} \\
{ }^{235} \mathrm{U} \\
{ }^{238} \mathrm{U}\end{array}$ & $\begin{array}{c}\text { Mass \% content } \\
0.02 \\
90.96 \\
8.2 \\
0.58 \\
0.25 \\
0.94 \% \text { by weight of } \\
\text { plutonium } \\
2.0 \\
98.0\end{array}$ \\
\hline $\begin{array}{l}\text { Average exposure rate at } 2 \mathrm{~m}(6.6 \mathrm{ft}) \text { from } \\
\text { external surface of transport cask, } \mu \mathrm{Sv} / \mathrm{h} \\
(\mathrm{mrem} / \mathrm{h})\end{array}$ & \multicolumn{2}{|r|}{$90(9)$} \\
\hline $\begin{array}{l}\text { Maximum anticipated dose rate at } 2 \mathrm{~m}(6.6 \mathrm{ft}) \\
\text { from external surface of transport cask, } \mu \mathrm{Sv} / \mathrm{h} \\
(\mathrm{mrem} / \mathrm{h})\end{array}$ & \multicolumn{2}{|c|}{$100(10)$} \\
\hline
\end{tabular}

Note: Canister shipments assumes three canisters per shipment in a transport cask. 


\subsection{Deactivation and Decontamination}

\subsection{Introduction}

This section describes the approach and methods that would be used to D\&D the proposed PIP. This description is based on modification and utilization of new buildings at SRS for plutonium conversion and immobilization. It assumes operations for a period of 10 years with an additional three years for the D\&D of the building. The building will not be demolished nor will the site be returned to greenfield conditions. Rather, the building will be decontaminated to levels that would permit unrestricted further use of the facility.

\subsection{Deactivation and Decontamination Approach}

This facility will contain approximately 50 gloveboxes (including those required for waste treatment) where the processing will take place. One of the most costeffective methods to D\&D a facility of this type is to remove the gloveboxes from the processing line and move them to a central area for decontamination and disassembly. The PIP will be a new building built under DNFSB oversight with possible NRC regulations. The facility will be designed so that gloveboxes can be easily disconnected and safely moved to a central location. Also, facility surfaces will be in constructed to permit ease of decontamination. Once the gloveboxes and equipment are removed, the facility surfaces will be decontaminated. All waste products generated will be packaged and removed to appropriate disposal sites.

\subsection{Decontamination Process Plan}

The first activity will be to review the operating records of the facility to determine the number and extent of spills, releases, and cleanup efforts that occurred during its operating lifetime. Next, a radiological survey of the facility and any outlying buildings, as well as their immediate surroundings, will be performed. These results will be entered into a data acquisition system. A cleanup criteria will be established, a D\&D plan prepared, and approval obtained from each government entity that has jurisdiction.

\subsection{Deactivation and Decontamination Operations}

Prior to equipment or glovebox removal from the facility, contamination surveys will be performed. All contamination will be either removed or fixed in place to eliminate generation of airborne particulates. Larger items of equipment will be prepared for removal by erecting temporary tents over them. Removal will 
be done by workers protected with respiratory equipment and layered anticontamination clothing. The equipment will be transferred into and out of transport vehicles through dock seals at both the sending and receiving locations. The transport vehicles will be lined to prevent contamination spread into cracks and crevices of the vehicle.

Upon receipt at the central cleaning and packaging facility, the contaminated equipment will be weighed and assayed to ensure that safe mass limits would not be exceeded with the introduction of the material into the decontamination cell. This assay will validate the facility characterization results and determine if there is excessive material holdup.

\subsection{Deactivation and Decontamination Generated Wastes and Emissions}

The types of waste generated from D\&D will include TRU waste from the plutonium and other actinide materials processed during the PIP 10-year operation. It would also include LLW and clean scrap metal and materials that could be recycled or buried in an authorized landfill. Depending on the D\&D method chosen, air and liquid emissions from the D\&D operations could produce dust or liquids containing radioactive and/or chemical particulates that would require treatment before discharge to the environment. The liquid treatment may include evaporation and particulate accumulation, filtration, ion exchange processes, and solidification. The selection of these processes would be dependent upon the nature and volume of the liquid involved and the most appropriate waste form for disposal.

The objective of the decontamination plan will be to effectively decontaminate to minimize the volume and weight of TRU waste for disposal and to maximize the amount of material resulting from D\&D that could be released for unrestricted use or disposed in unrestricted landfills. Any material not in the above two categories would be sent either to a LLW repository on-site or to a commercial LLW facility off-site. 


\subsection{List of Abbreviations and Acronyms}

$\begin{array}{ll}\text { ANS } & \text { American Nuclear Society } \\ \text { ANSI } & \text { American National Standards Institute } \\ \text { ANSTO } & \text { Australian Nuclear Science Technology Organisation } \\ \text { APSF } & \text { Actinide Packaging and Storage Facility } \\ \text { ARMS } & \text { advance recycling media system } \\ \text { BNFO } & \text { Bechtel Nuclear Fuel Operations } \\ \text { BNL } & \text { Brookhaven National Laboratory } \\ \text { C } & \text { coulomb } \\ \text { CAS } & \text { criticality alarm system } \\ \text { CCTV } & \text { closed-circuit television } \\ \text { cfm } & \text { cubic feet per minute } \\ \text { CFR } & \text { Code of Federal Regulations } \\ \text { CIF } & \text { consolidated incinerator facility } \\ \text { cm } & \text { centimeters } \\ \text { CRT } & \text { container restraint transport } \\ \text { Cs } & \text { cesium } \\ \text { CWC } & \text { central waste complex } \\ \text { DAS } & \text { data acquisition system } \\ \text { D\&D } & \text { deactivation and decontamination } \\ \text { D\&R } & \text { demolition and removal } \\ \text { DBA } & \text { design basis accident } \\ \text { DBE } & \text { design basis earthquake } \\ \text { DBF } & \text { design basis flood } \\ \text { DBT } & \text { design basis tornado } \\ \text { DNFSB } & \text { Defense Nuclear Facility Safety Board } \\ \text { DOE } & \text { Department of Energy } \\ \text { DOT } & \text { Department of Transportation } \\ \text { DWPF } & \text { Defense Waste Processing Facility } \\ \text { EIS } & \text { Environmental Impact Statement } \\ \text { EM } & \text { environmental management } \\ \text { EPA } & \text { Environmental Protection Agency } \\ \text { EPRI } & \text { Electric Power Research Institute } \\ \text { ES\&H } & \text { environment, safety, and health } \\ \text { ETF } & \text { Effluent Treatment Facility } \\ \text { FFTF } & \text { Fast Flux Test Facility } \\ \text { FAA } & \text { fuel assembly area } \\ \text { FMEF } & \text { fuels and materials examination facility } \\ \text { ft } & \text { foot } \\ \text { FTE } & \text { full-time equivalent } \\ \text { gpd } & \text { gallons per day } \\ \text { gpm } & \text { gallons per minute } \\ \text { GWh } & \text { gigawatt hours } \\ & \end{array}$




$\begin{array}{ll}\text { GWSB } & \text { Glass Waste Storage Building } \\ \text { h } & \text { hour } \\ \text { HEPA } & \text { high-efficiency particulate air } \\ \text { HEU } & \text { highly enriched uranium } \\ \text { HLW } & \text { high-level waste } \\ \text { HVAC } & \text { heating, ventilation, and air conditioning } \\ \text { HWVP } & \text { Hanford Waste Vitrification Plant } \\ \text { HYDOX } & \text { hydride oxidation } \\ \text { IAEA } & \text { International Atomic Energy Agency } \\ \text { I\&C } & \text { instrumentation and controls } \\ \text { IEEE } & \text { Institute of Electrical and Electronics Engineers } \\ \text { in } & \text { inch } \\ \text { INEL } & \text { Idaho National Engineering Laboratory } \\ \text { IPE } & \text { Investment Protection Earthquake } \\ \text { keff } & \text { effective neutron multiplication factor } \\ \text { kg } & \text { kilogram } \\ \text { LaBS } & \text { lanthanide borosilicate } \\ \text { lb } & \text { pound } \\ \text { kV } & \text { kilovolt } \\ \text { LLNL } & \text { Lawrence Livermore National Laboratory } \\ \text { LLW } & \text { low level waste } \\ \text { Lpd } & \text { liters per day } \\ \text { Lpm } & \text { liters per minute } \\ \text { m } & \text { meter } \\ \text { MAA } & \text { material access area } \\ \text { MD } & \text { materials disposition } \\ \text { MC\&A } & \text { material control and accountability } \\ \text { MOX } & \text { mixed oxide (fuel) } \\ \text { MPa } & \text { megapascals } \\ \text { mrem } & \text { milli-Roentgen equivalent man } \\ \text { mSv } & \text { milli-Sievert } \\ \text { M W } & \text { megawatt } \\ \text { NAS } & \text { National Academy of Sciences } \\ \text { NCSE } & \text { nuclear criticality safety evaluation report } \\ \text { NDA } & \text { non-destructive assay } \\ \text { NESHAPS } & \text { National Emissions Standards for Hazardous Air Pollutants } \\ \text { NEPA } & \text { National Environmental Protection Act } \\ \text { NFPA } & \text { National Fire Protection Association } \\ \text { NHSTA } & \text { National Highway Traffic Safety Administration } \\ \text { NIM } & \text { nuclear incident monitor } \\ \text { NMC\&A } & \text { nuclear material control and accountability } \\ \text { NRC } & \text { Nuclear Regulatory Commission } \\ \text { NRDSF } & \text { Nonradioactive Dangerous Waste Storage Facility } \\ \text { NSR } & \text { new special recovery } \\ \text { ORNL } & \text { Oak Ridge National Laboratory } \\ \text { OSHA } & \text { Occupational Safety and Health Administration } \\ & \end{array}$




\begin{tabular}{|c|c|}
\hline PAP & personal assurance program \\
\hline PEIS & Programmatic Environmental Impact Statement \\
\hline PIDAS & perimeter intrusion detection and assessment system \\
\hline PIP & Plutonium Immobilization Plant \\
\hline PNNL & Pacific Northwest National Laboratory \\
\hline PSAP & personal security assurance program \\
\hline PSF & Plutonium Storage Facility \\
\hline psi & pounds per square inch \\
\hline psig & pounds per square inch gauge \\
\hline $\mathrm{Pu}$ & plutonium \\
\hline $\mathrm{R}$ & roetgen \\
\hline RCRA & Resource Conservation and Recovery Act \\
\hline REE & rare earth elements \\
\hline RD\&T & research, development, and testing \\
\hline redox & reduction oxidation \\
\hline ROD & record of decision \\
\hline s & second \\
\hline SAF & secure automated fabrication \\
\hline SAR & safety analysis report \\
\hline SAS & secondary alarm station \\
\hline scf & standard cubic feet \\
\hline SFM & surplus fissile material \\
\hline SGT & safeguard transporter \\
\hline SIP & storage interface processor \\
\hline SIS & special isotope separation \\
\hline SNM & special nuclear material \\
\hline $\mathrm{SPO}$ & security police officer \\
\hline$S / R$ & storage/retrieval \\
\hline SRS & Savannah River Site \\
\hline SSC & systems, structures, and components \\
\hline SST & safe secure transport \\
\hline SYNROC & synthetic rock \\
\hline TBD & to be determined \\
\hline TID & tamper-indicating device \\
\hline TPSS & two-person surveillance system \\
\hline TRU & transuranic \\
\hline UBC & Uniform Building Code \\
\hline UCNI & unclassified controlled nuclear information \\
\hline UCRL & University of California Radiation Laboratory \\
\hline $\mathrm{UO}_{\mathrm{x}}$ & uranium oxides \\
\hline UPS & uninterruptible power supply \\
\hline V A & vulnerability assessment \\
\hline VRC & vertical reciprocal conveyor \\
\hline WAC & waste acceptance criteria \\
\hline WIPP & Waste Isolation Pilot Plant \\
\hline
\end{tabular}


UCRL-ID-128271

$\begin{array}{ll}\text { WRAP } & \text { waste receiving and processing } \\ \text { XRF } & \text { x-ray fluoresence } \\ \text { y } & \text { year } \\ \text { ZPPR } & \text { Zero Power Physics Reactor }\end{array}$


UCRL-ID-128271

\section{Appendix A}

\section{Hybrid Case}


UCRL-ID-128271

A-2 


\section{Summary}

The impact of a lower design throughput (hybrid case) for the immobilization of plutonium in glass using new facilities and the existing DWPF at the SRS was studied. The facility described in this appendix is based on a total capacity of 18.2 tonnes (20 tons) of surplus plutonium material over a 10-year period.

The design layout developed for the 50 tonne case (the base case) will be used for this hybrid case; therefore, the number of employees during construction will stay the same. The plutonium conversion portion of the facility for the hybrid case will operate at the same design rate as the base case. The immobilization portion of the facility will be assumed to operate with installed spares or possibly fewer shifts for the hybrid case. Some of the process equipment may not be used or will operate for a shorter period of time. Therefore, fewer operators will be required.

The following operational quantities will be affected:

- Resource needs or consumable materials

- Employment requirements

- Estimated waste generation

- Process air emissions

- Radioactive releases.

The major changes due to the hybrid case are shown in this appendix (Tables A-1 through A-7). Assumptions, missions, design bases, facility and process descriptions, and accident analyses have not changed and can be found in the base case. 
UCRL-ID-128271

Table A-1. Resource needs during operation (refer to Table 5-2, base case).

\begin{tabular}{|l|c|}
\hline \multicolumn{1}{|c|}{ Resource requirement } & Annual average consumption \\
\hline Utilities & 10,650 \\
\hline Electricity, MWh & 2.0 \\
Peak demand, MW & $445(491)$ \\
\hline Coal, tonne (ton) & $0(0)$ \\
Natural gas, ${ }^{3}$ (scf) & $0(0)$ \\
Oil, L (gal) & $25,000(6,605)$ \\
Diesel fuel, L (gal) & $4,100(1083)$ \\
Gasoline, on-site transportation, L (gal) & $47,450,000(12,536,290)$ \\
\hline Groundwater, L (gal) & $45,000(11,890)$ \\
Peak demand & $0(0)$ \\
Surface water, L (gal) & $0(0)$ \\
Peak demand & \\
\hline Process chemicals & $260(9,181)$ \\
\hline Gases, ${ }^{3}$ (scf) & $230(8,121)$ \\
Hydrogen & $95(3,354)$ \\
Oxygen & $380(13,418)$ \\
Nitrogen & $2,200(77,682)$ \\
Argon & \\
Helium & $110(29.06)$ \\
\hline Liquids, L (gal) & $29,000(63,945)$ \\
Process water & $55,000(121,000)$ \\
\hline Solids, kg (lb) & $1,100(2,400)$ \\
Frit & \\
S/S canister, canister rack, & \\
product cans & \\
Absorbents & \\
\hline
\end{tabular}


Table A-1. (cont.)

\begin{tabular}{|l|c|}
\hline Non-process chemicals & \\
\hline Gases, $\mathrm{m}^{3}$ (scf) & $70,000(2,471,700)$ \\
Argon (includes canister welding, & \\
bagless loadout) & $710(25,345)$ \\
Nitrogen & $120(4,251)$ \\
Helium & \\
\hline Liquids, L (gal) & $400(106)$ \\
Hydraulic fluid & $200(53)$ \\
Cutting oil & $1,150(304)$ \\
Lubricating oil & \\
\hline Solids, kg (lb) & \\
Film development chemicals & $4.0(8.82)$ \\
Ammonium thiosulfate & $2.0(4.5)$ \\
Sodium sulfate & $2.0(4.5)$ \\
Potassium sulfate & $1.0(2.25)$ \\
Hydroquinone & $1.0(2.25)$ \\
Glutaraldehyde & $1.0(2.25)$ \\
Potassium acetate & $57.0(126)$ \\
Sodium hypoclorite & $84.1(185)$ \\
Polyphosphate & $100(222)$ \\
Corrosion inhibitor & \\
\hline Radioactive materials used in process & $1.82(2.01)$ \\
\hline Pu, tonne (ton) - feed material & $1.66(1.83)$ \\
U, tonne (ton) - feed material & $0(0)$ \\
U, tonne (ton) - depleted uranium & \\
\hline Nots: & \\
\hline
\end{tabular}

Notes:

- Peak demand is the maximum rate expected during any hour.

- For gases, standard cubic feet should be measured at $101 \mathrm{kPa}(14.7 \mathrm{psia})$ and $15^{\circ} \mathrm{C}\left(60^{\circ} \mathrm{F}\right)$.

- Coal consumption is for steam heating.

- Diesel fuel consumption is based on weekly one-hour testing of diesel generators for standby power.

- Gasoline consumption assumes four vehicles driven $32 \mathrm{~km}$ (20 miles) per day at $7.7 \mathrm{~km} / \mathrm{L}$ (18 mpg).

- Groundwater consumption is based on a DOE standard for drinking and sanitary usage, as well as cooling tower make-up water.

- Absorbent weight assumes a minimum 10:1 ratio of solid to liquid weight to dispose of spills and decontamination liquids as solid waste.

- Film development chemicals assume radiography of 70 canister welds per year, using a total of $38 \mathrm{~L}$ (10 gal) of "fixer" (ammonium thiosulfate/sodium sulfate) and $38 \mathrm{~L}$ (10 gal) of "developer" (potassium sulfate/hydroquinone/potassium acetate/glutaraldehyde). 
Table A-2. Annual employment requirements during operation (refer to Table 6-2, base case).

\begin{tabular}{|c|c|c|c|c|}
\hline Labor category & $\begin{array}{l}\text { Number of } \\
\text { shifts }\end{array}$ & $\begin{array}{l}\text { Number of } \\
\text { employees } \\
\text { per shift }\end{array}$ & $\begin{array}{l}\text { Total number of } \\
\text { employees }\end{array}$ & $\begin{array}{c}\text { Number of } \\
\text { operating days } \\
\text { per year }\end{array}$ \\
\hline $\begin{array}{l}\text { Officials and } \\
\text { managers }\end{array}$ & 1 & 5 & 5 & 240 \\
\hline $\begin{array}{l}\text { Professionals } \\
\text { Tech support }\end{array}$ & 1 & 11 & 11 & 240 \\
\hline $\begin{array}{l}\text { Technicians } \\
\text { Operations } \\
\text { RCO } \\
\text { Lab support } \\
\text { Shift supv }\end{array}$ & $\begin{array}{l}5 \\
5 \\
5 \\
5\end{array}$ & $\begin{array}{c}20 \\
6 \\
4 \\
4\end{array}$ & $\begin{array}{l}100 \\
30 \\
20 \\
20\end{array}$ & $\begin{array}{l}365 \\
365 \\
365 \\
365\end{array}$ \\
\hline $\begin{array}{l}\text { Office and clerical } \\
\text { Ops support } \\
\text { Clerical }\end{array}$ & $\begin{array}{l}1 \\
1\end{array}$ & $\begin{array}{c}10 \\
4\end{array}$ & $\begin{array}{c}10 \\
4\end{array}$ & $\begin{array}{l}240 \\
240\end{array}$ \\
\hline $\begin{array}{l}\text { Craft workers } \\
\text { (skilled) } \\
\text { Maintenance }\end{array}$ & 5 & 6 & 30 & 365 \\
\hline $\begin{array}{l}\text { Service workers } \\
\text { Security } \\
\end{array}$ & 4 & 4 & 16 & 365 \\
\hline Total & & & 246 & \\
\hline
\end{tabular}

Notes:

- New positions to support immobilization.

- Security for intrasite shipment of canisters and unloading of canisters to the DWPF melt cell will be provided by existing site mobile protective force personnel.

Table A-3. Radiation doses to on-site workers during operations (refer to Table 6-4, base case).

\begin{tabular}{|l|c|}
\hline $\begin{array}{l}\text { Average annual effective dose equivalent to all badged workers at the } \\
\text { facility, } \mu \mathrm{Sv} / \mathrm{y}(\mathrm{mrem} / \mathrm{y})\end{array}$ & $\begin{array}{c}7,500 \\
(750)\end{array}$ \\
\hline $\begin{array}{l}\text { Maximum effective dose equivalent to a badged worker at the facility, } \\
\mu \mathrm{Sv} / \mathrm{y}(\mathrm{mrem} / \mathrm{y})\end{array}$ & $\begin{array}{c}20,000 \\
(2,000)\end{array}$ \\
\hline Total number of badged workers & 232 \\
\hline
\end{tabular}


Table A-4. Estimated waste generation during operation (refer to Table 7-4, base case).

\begin{tabular}{|c|c|c|c|c|}
\hline Waste category & $\begin{array}{l}\text { Annual } \\
\text { volume }\end{array}$ & $\begin{array}{c}\text { Total } \\
\text { estimated } \\
\text { volume }\end{array}$ & Description & $\begin{array}{l}\text { Anticipated treatment } \\
\text { method }\end{array}$ \\
\hline $\begin{array}{l}\text { Transuranic } \\
\text { Liquid, L (gal) } \\
\text { Solid, } \mathrm{m}^{3}\left(\mathrm{ft}^{3}\right)\end{array}$ & $\begin{array}{c}280(74) \\
95(3,355)\end{array}$ & $\begin{array}{r}2,800(740) \\
950(33,550)\end{array}$ & $\begin{array}{l}\text { Liquid lab waste, } \\
\text { ZPPR fuel cladding, } \\
\text { FFTF fuel rods, } \\
\text { combustibles, glass, } \\
\text { filters, job-control } \\
\text { waste, failed process } \\
\text { equipment }\end{array}$ & $\begin{array}{l}\text { Liquid waste dicharged } \\
\text { to tank farm and } \\
\text { evaporation prior to } \\
\text { DWPF. Solid waste } \\
\text { packaged \& stored in } \\
\text { aboveground storage on- } \\
\text { site until shipped to } \\
\text { WIPP. }\end{array}$ \\
\hline $\begin{array}{l}\text { Low level } \\
\text { Liquid, } \mathrm{L} \text { (gal) } \\
\text { Solid, } \mathrm{m}^{3}\left(\mathrm{ft}^{3}\right)\end{array}$ & $\begin{array}{c}0(0) \\
60(2,119)\end{array}$ & $\begin{array}{c}0(0) \\
600(21,190)\end{array}$ & $\begin{array}{l}\text { Combustibles, filters, } \\
\text { gloves, glass }\end{array}$ & $\begin{array}{l}\text { Compacted, packaged } \\
\text { and stored in aboveground } \\
\text { low level storage vaults } \\
\text { on-site. }\end{array}$ \\
\hline $\begin{array}{l}\text { Mixed LLW } \\
\text { Liquid, L (gal) } \\
\text { Solid, } \mathrm{m}^{3}\left(\mathrm{ft}^{3}\right)\end{array}$ & $\begin{array}{l}0(0) \\
1(35)\end{array}$ & $\begin{array}{c}0(0) \\
10(350)\end{array}$ & $\begin{array}{l}\text { Failed equipment, } \\
\text { grease, and leaded } \\
\text { shielding. }\end{array}$ & $\begin{array}{l}\text { Packaged and stored in } \\
\text { aboveground mixed, low } \\
\text { level storage vaults on- } \\
\text { site. }\end{array}$ \\
\hline $\begin{array}{l}\text { Hazardous } \\
\text { Liquid, L (gal) } \\
\text { Solid, } \mathrm{m}^{3}\left(\mathrm{ft}^{3}\right)\end{array}$ & $\begin{array}{c}4,500(1,191) \\
25(883)\end{array}$ & $\begin{array}{c}45,000 \\
(11,910) \\
250(8,830)\end{array}$ & $\begin{array}{l}\text { Chemicals, } \\
\text { lubrication oils, } \\
\text { paint, radiographic } \\
\text { wastes, batteries, } \\
\text { fluorescent light tubes }\end{array}$ & $\begin{array}{l}\text { Thermal decomposition, } \\
\text { packaged and stored in } \\
\text { aboveground mixed, low } \\
\text { level storage vaults on- } \\
\text { site. }\end{array}$ \\
\hline $\begin{array}{l}\text { Nonhazardous } \\
\text { (sanitary) } \\
\text { Liquid, L (gal) } \\
\text { Solid, } \mathrm{m}^{3}\left(\mathrm{ft}^{3}\right)\end{array}$ & $\begin{array}{l}1.78 \times 10^{7} \\
\left(4.7 \times 10^{6}\right) \\
230(8,122)\end{array}$ & $\begin{array}{c}1.78 \times 10^{8} \\
\left(4.7 \times 10^{7}\right) \\
2,300(81,220)\end{array}$ & $\begin{array}{l}\text { Sanitary sewage, } \\
\text { filters, FFTF fuel } \\
\text { housing, office and } \\
\text { shop waste }\end{array}$ & $\begin{array}{l}\text { Liquid wastes discharged } \\
\text { to sanitary sewer. Solid } \\
\text { wastes deposited in } \\
\text { landfill. }\end{array}$ \\
\hline $\begin{array}{l}\text { Nonhazardous } \\
\text { (other) } \\
\text { Liquid, L (gal) }\end{array}$ & $\begin{array}{c}8.02 \times 10^{6} \\
\left(2.12 \times 10^{6}\right) \\
30(34.4)\end{array}$ & $\begin{array}{c}8.02 \times 10^{7} \\
\left(2.12 \times 10^{7}\right) \\
300(344)\end{array}$ & $\begin{array}{l}\text { Cooling tower blow- } \\
\text { down, coal ash }\end{array}$ & $\begin{array}{l}\text { Blowdown water } \\
\text { discharged to permitted } \\
\text { outfall. Ash deposited in } \\
\text { landfill. }\end{array}$ \\
\hline
\end{tabular}

Notes:

- Clean metal material less than 9.07 tonnes (10 tons) per year will be recycled.

- TRU waste volume assumes about $10 \%$ annual equipment failure rate. This volume also includes waste from annual glovebox glove changeout.

- Mixed TRU waste includes waste volume from leaded glove changeout.

- Nonhazardous sanitary waste based on DOE standards.

- Nonhazardous (other) solid waste is coal ash, estimated at $7 \%$ of coal weight. 
UCRL-ID-128271

Table A-5. Radioactive releases during operation (refer to Table 7-6, base case).

\begin{tabular}{|c|c|c|c|}
\hline Radionuclide & $\begin{array}{c}\text { Release, } \\
\mathrm{kBq} / \mathrm{y}(\mu \mathrm{Ci} / \mathrm{y})\end{array}$ & $\begin{array}{c}\text { Average } \\
\text { release height, } \\
\text { m (ft) }\end{array}$ & $\begin{array}{c}\text { Release point } \\
\text { coordinates } \\
\text { (lat./long.) }\end{array}$ \\
\hline Air & & \multirow{8}{*}{$\begin{array}{l}59(195) \\
\text { for all process } \\
\text { releases. }\end{array}$} & \multirow{8}{*}{$\begin{array}{c}33^{\circ} 17^{\prime} 30^{\prime \prime} \mathrm{N} / \\
81^{\circ} 40^{\prime} 14^{\prime \prime} \mathrm{W} \\
\text { for all process } \\
\text { releases }\end{array}$} \\
\hline${ }^{241} \mathrm{~A} \mathrm{~m}$ & $80(2.17)$ & & \\
\hline${ }^{239} \mathrm{Pu}$ & $125(3.37)$ & & \\
\hline${ }^{240} \mathrm{Pu}$ & $59(1.58)$ & & \\
\hline${ }^{241} \mathrm{Pu}$ & $3,615(97.7)$ & & \\
\hline${ }^{242} \mathrm{Pu}$ & $4.4 \times 10^{-2}\left(1.2 \times 10^{-3}\right)$ & & \\
\hline${ }^{235} \mathrm{U}$ & $8.5 \times 10^{-5}\left(2.3 \times 10^{-6}\right)$ & & \\
\hline${ }^{238} \mathrm{U}$ & $6.9 \times 10^{-4}\left(85 \times 10^{-5}\right)$ & & \\
\hline Surface water & & & \\
\hline No releases & & & \\
\hline
\end{tabular}

Notes:

- $\quad$ Total release $=3.9 \times 10^{3} \mathrm{kBq} / \mathrm{y}(105 \mu \mathrm{Ci} / \mathrm{y})$.

- Volumetric flow: $100 \mathrm{~m}^{3} / \mathrm{s}\left(3.5 \times 10^{3} \mathrm{cfs}\right)$.

- Stack cross-sectional area: $13.3 \mathrm{~m}^{2}\left(143 \mathrm{ft}^{2}\right)$.

- Exit velocity: $7 \mathrm{~m} / \mathrm{s}(23 \mathrm{ft} / \mathrm{s})$.

- Exit temperature: $35^{\circ} \mathrm{C}\left(95^{\circ} \mathrm{F}\right)$.

- Air emissions are based on the following assumptions:

$1 \%$ of material inside a glovebox is outside of containment (vessel, can, etc.).

$1 \%$ of the material outside of containment is dispersible.

Two stages of HEPA filtration at $99.97 \%$ efficiency provided prior to discharge to stack.

Isotopic distribution of feed material is:

$\begin{array}{ll}{ }^{239} \mathrm{Pu} & 86.9 \% \\ { }^{240} \mathrm{Pu} & 11.1 \% \\ { }^{241} \mathrm{Pu} & 1.5 \% \\ { }^{242} \mathrm{Pu} & 0.5 \% \\ { }^{241} \mathrm{Am} & 1 \% \text { by weight of plutonium } \\ { }^{235} \mathrm{U} & 2.0 \% \\ { }^{238} \mathrm{U} & 98.0 \%\end{array}$


Table A-6. Process material shipments during operation (refer to Table 9-2, base case).

\begin{tabular}{|c|c|c|}
\hline $\begin{array}{l}\text { Number of shipments of non-pit materials to plutonium } \\
\text { conversion and immobilizationfacility from: } \\
\text { Hanford } \\
\text { INEL } \\
\text { LANL } \\
\text { LLNL } \\
\text { RFETS } \\
\text { SRS }\end{array}$ & \multicolumn{2}{|l|}{$\begin{array}{r}90-200^{1} \\
41 \\
34 \\
3 \\
90 \\
35\end{array}$} \\
\hline Container types used for shipments & \multicolumn{2}{|c|}{$\begin{array}{l}9975 \\
\text { SAF KEG } \\
6 \mathrm{M} / 2 \mathrm{R} \\
3013 \\
\text { Foodpac } \\
\text { Radial reflector cask (FFTF } \\
\text { fuel assembly) } \\
\text { Model } 60 \text { FFTF DFA pins } \\
\text { shipping container } \\
\end{array}$} \\
\hline \multicolumn{3}{|l|}{ Availability of shipping containers ${ }^{2}$} \\
\hline Average empty container weight, kg (lb) & \multicolumn{2}{|l|}{$165(364)$} \\
\hline Average bulk material weight, $\mathrm{kg}(\mathrm{lb})$ & \multicolumn{2}{|l|}{$4.4(9.7)$} \\
\hline Average isotopic content & $\begin{array}{l}\frac{\text { By isotope }}{{ }^{239} \mathrm{Pu}} \\
{ }^{240} \mathrm{Pu} \\
{ }^{241} \mathrm{Pu} \\
{ }^{242} \mathrm{Pu} \\
{ }^{241} \mathrm{~A} \mathrm{~m} \\
{ }^{235} \mathrm{U} \\
{ }^{238} \mathrm{U}\end{array}$ & $\begin{array}{l}\text { Mass } \% \text { content } \\
86.9 \% \\
11.1 \\
1.5 \\
0.5 \\
1 \% \text { by weight } \\
\text { of plutonium } \\
2.0 \\
98.0\end{array}$ \\
\hline $\begin{array}{l}\text { Average exposure rate at } 2 \mathrm{~m}(6.6 \mathrm{ft}) \text { from external } \\
\text { surface of transport vehicle, } \mu \mathrm{Sv} / \mathrm{h}(\mathrm{mrem} / \mathrm{h})\end{array}$ & \multicolumn{2}{|r|}{$90(9)$} \\
\hline $\begin{array}{l}\text { Maximum anticipated dose rate at } 2 \mathrm{~m}(6.6 \mathrm{ft}) \text { from } \\
\text { external surface of transport vehicle, } \mu \mathrm{Sv} / \mathrm{h}(\mathrm{mrem} / \mathrm{h})\end{array}$ & \multicolumn{2}{|c|}{$100(10)$} \\
\hline
\end{tabular}

Notes:

1. 90 shipments for 3013 container, 200 shipments for Foodpac container.

2. Container availability: Type 9975 (for oxides) safety analysis under review for certification for oxides; SAF KEG type (for oxide) container safety analysis under review for certification; specification $6 \mathrm{M} / 2 \mathrm{R}$ (for metal/oxide) covers approximately 10,000 containers of various approved designs availiable in 30 and 55 gallon sizes; radial reflector casks TBD; Model 60 FFTF DFA pins shipping container TBD 
Table A-7. Intrasite transport of "canned" plutonium to the facility (refer to Table 9-2, base case).

\begin{tabular}{|c|c|c|}
\hline $\begin{array}{l}\text { Number of intrasite shipments of "canned" } \\
\text { plutonium to modified HLW vitrification facility }\end{array}$ & \multicolumn{2}{|c|}{$\begin{array}{l}\text { Annual shipments } \\
25\end{array}$} \\
\hline $\begin{array}{l}\text { Container (transport cask) types used for } \\
\text { shipments }\end{array}$ & \multicolumn{2}{|c|}{ New design } \\
\hline Availability of containers & \multicolumn{2}{|c|}{ To be designed } \\
\hline Average shipping container weight, $\mathrm{kg}(\mathrm{lb})$ & \multicolumn{2}{|c|}{ TBD } \\
\hline $\begin{array}{l}\text { Average material weight in canister, } \mathrm{kg}(\mathrm{lb}) \\
\text { Material weight in canister includes plutonium- } \\
\text { glass [329 kg (724 lb)], cans [203 kg ( } 447 \mathrm{lb})] \text {, and } \\
\text { rack assembly [50 kg (110 lb)] }\end{array}$ & \multicolumn{2}{|c|}{$582(1281)$} \\
\hline Weight of empty canister, $\mathrm{kg}(\mathrm{lb})$ & \multicolumn{2}{|c|}{$450(992)$} \\
\hline $\begin{array}{l}\text { Average isotopic content } \\
\qquad\left(\mathrm{U} \text { in } \mathrm{UO}_{2} \text { is } 100 \%{ }^{238} \mathrm{U}\right)\end{array}$ & $\begin{array}{l}\begin{array}{c}\text { By } \\
\text { Isotope }\end{array} \\
{ }^{239} \mathrm{Pu} \\
{ }^{240} \mathrm{Pu} \\
{ }^{241} \mathrm{Pu} \\
{ }^{242} \mathrm{Pu} \\
{ }^{241} \mathrm{~A} \mathrm{~m} \\
{ }^{235} \mathrm{U} \\
{ }^{238} \mathrm{U}\end{array}$ & $\begin{array}{c}\text { Mass \% } \\
\text { content } \\
86.9 \\
11.1 \\
1.5 \\
0.5 \\
1 \% \text { by } \\
\text { weight of } \\
\text { plutonium } \\
2.0 \\
98.0 \\
\end{array}$ \\
\hline $\begin{array}{l}\text { Average exposure rate at } 2 \mathrm{~m}(6.6 \mathrm{ft}) \text { from } \\
\text { external surface of transport cask, } \mu \mathrm{Sv} / \mathrm{h} \\
(\mathrm{mrem} / \mathrm{h})\end{array}$ & \multicolumn{2}{|c|}{$90(9)$} \\
\hline $\begin{array}{l}\text { Maximum anticipated dose rate at } 2 \mathrm{~m}(6.6 \mathrm{ft}) \\
\text { from external surface of transport cask, } \mu \mathrm{Sv} / \mathrm{h} \\
(\mathrm{mrem} / \mathrm{h})\end{array}$ & \multicolumn{2}{|c|}{$100(10)$} \\
\hline
\end{tabular}

Note: Canister shipments assumes three canisters per shipment in a transport cask. 
